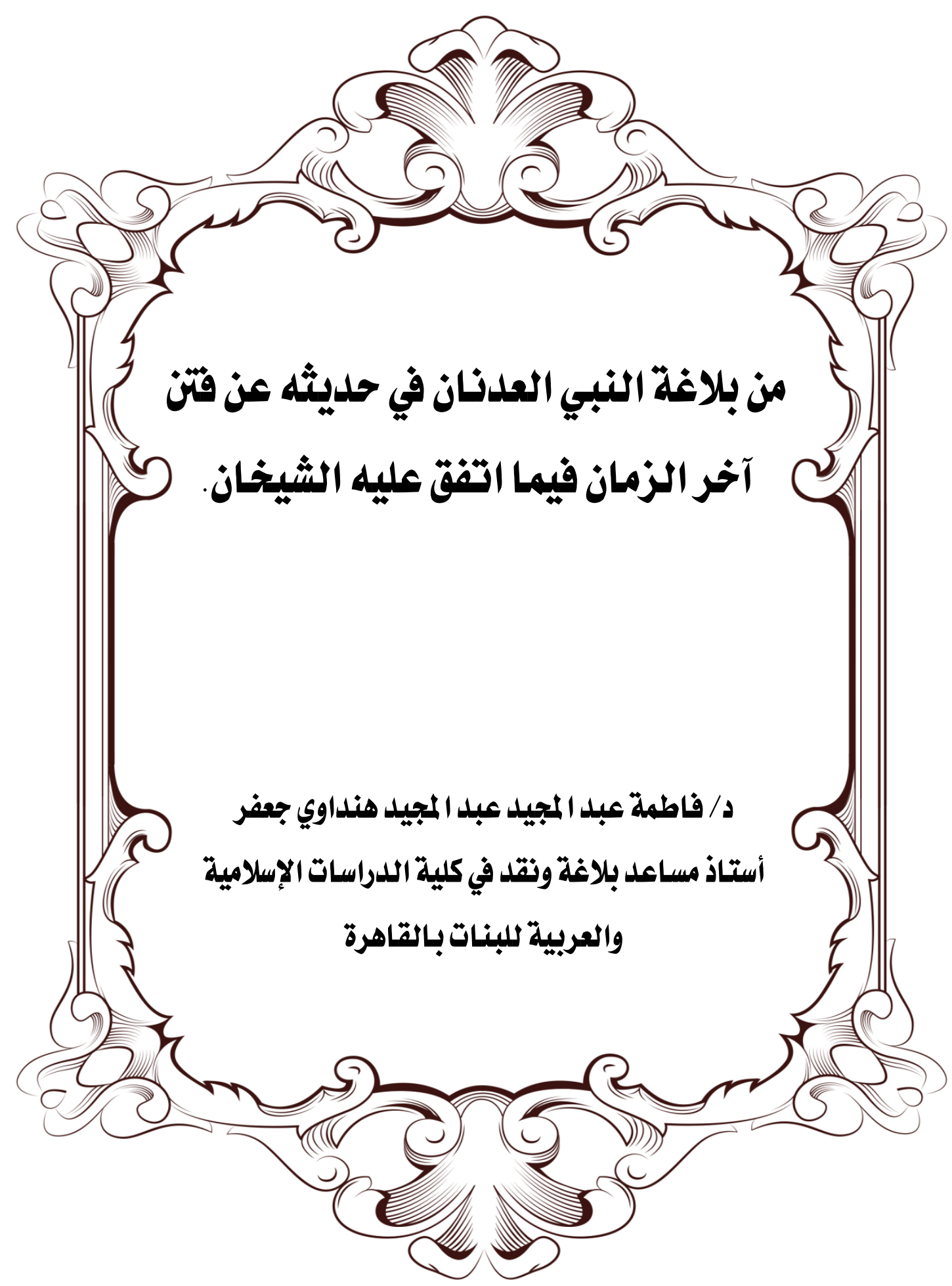


هن بلاغة النبي العدنان في دديثه عن فتن آذر الزهان فيها اتفق عليه الشيخان.

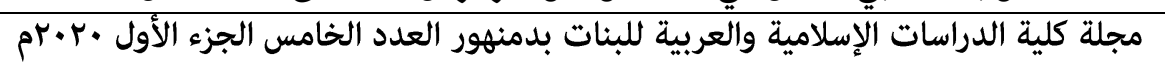


من بلاغة النبي العدنان في دديثه عن فتن آذر الزهان فيها اتفق عليه الشيخان.

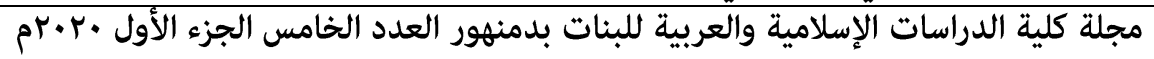

من بلاغة النبي العدنان في حديثه عن فتن آخر الزمان فيما اتفق عليه الثيخان.

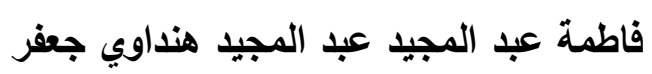

قسم البلاغة والنقد في كلية الدراسات الإسلامية والعربية للبنات بالقاهرة

FatmaHindawy1507.el@azhar.edu.eg : البريد الإكتروني

الملخص

هذا البحث في مجال البلاغة النبوية، في موضوع الفتن وعلامات

$$
\text { قرب الساعة، جاء في مقدمة وتمهيد وثلاثة مباحث. }
$$

اشتمل البحث على دراسة بلاغية ل ب r حديثا موزعة على المباحث

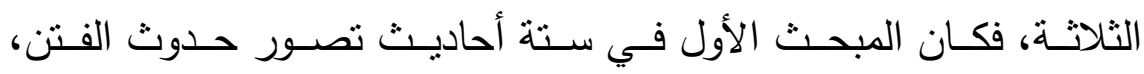
ومواطنها، والواجب على الناس حين ظهورها، وتنص على خراب الكعبة، وما سيحدث في الإمارة، وتمني الناس الموت.

أما المبحث الثاني فكان في سبعة أحاديث تخبر بكثرة القتل والخسف

$$
\text { وخروج نار من أرض الحجاز • }
$$

والمبحث الثالث فكان في ثمانية أحاديث تخبر بكثرة الكذابين وقرب خروج الاجال ويأجوج ومأجوج.

ثم الخاتمة وفيها نتائج البحث، ثم ثبت المصادر

$$
\text { الكلمات المفتاحية : بلاغة - العدنان - فتن - الزمان - الثيخان }
$$




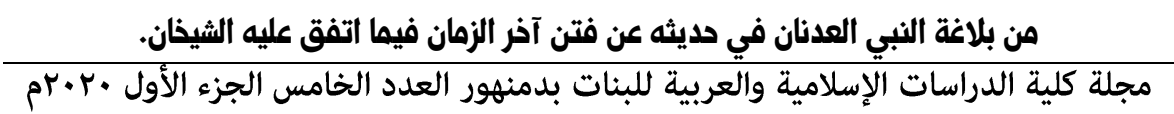

From the rhetoric of the Prophet Adnan in his discussion of the

.temptation of the end of time, as the two sheikhs agreed

Fatima Abdul Majeed Abdul Majeed Hindawi Jaafar

The Department of Rhetoric and Criticism at the Faculty of Islamic and Arab Studies for Girls in Cairo

\section{E-mail: FatmaHindawy1507.el@azhar.edu.eg}

\section{Abstract:}

This research is in the field of prophetic rhetoric, on the topic of sedition and signs near the hour (the end of the world). The research is divided into an introduction, a preface and three chapters.

The research included a rhetorical study of 22 hadiths distributed among the three chapters, so the first chapter handled six hadiths depicting the occurrence of temptations (disorders), its habitats, and the duty of people when they emerged, and stating the ruin of the Kaaba, and what will happen in the emirate, and people's wish to die. As for the second chapter, it included seven hadiths informing about the abundance of the killing, the loss, and the exit of fire from the Hijaz land.

And the third chapter handled eight hadiths informing the large number of liars and the imminence of the Antichrist's and Gog and Magog's coming. The conclusion contained the results of the research then came the references.

$\underline{\text { Keywords: eloquence - Adnan - Faten - Time - The two sheikhs }}$ 
من بلاغة النبي العدنان في دلايثه عن فتن آذر الزمان فيها اتفق عليه الشيخان.

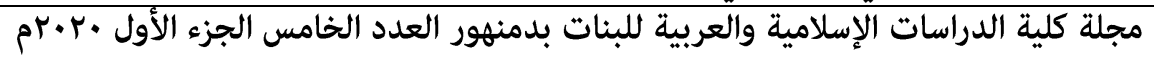

مقدمة مجلة

الحمد لله رب العالمين مالك يوم الدين، والصلاة والسلام على

المبعوث رحمة للعالمين، الثفيع يوم لا شفيع، الذي صدق من قال الله فيه:

"بالمؤمنين رؤوف رحيم".

وبعد

فهذا بلاغي في أحاديث سيد البلغاء، وأفصح الناطقين بلغة الضاد،

صاحب المقام الأعلى، والبيان البشري الأسمى، في موضوع تظهر أماراته، باءن،

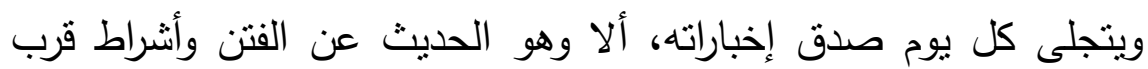

الساعة وانتهاء الزمان.

وهو بعنوان: من بلاغة النبي العدنان في حديثه عن فتن آخر

الزمان فيما اتفق عليه الثيخان.

تتاولت فيه من أحاديث النبي الرحيم عليه صلوات الهه وسلامه

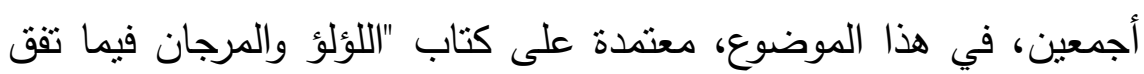

عليه الثيخان" جمع محمد فؤاد عبد الباقي، حيث اتبع ترتيب الإمام مسلم

في صحيحه فجمع أحاديث الفنن كلها في كتاب الفتن، بينما تعدد الأبواب

الوارد فيها أحاديث البخاري في صحيحه، فاعتمد نرتيب مسلم، وذكر تخريج

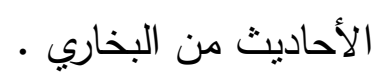

ثم انتقيت من الأحاديث من هو وثثق الصلة بهذا الزمن وما سيليه، علها تكون تذكرة لي ولمن يقرأ، وتتبيها على ما فات عله بيتدرك. وقد اتبعت المنهجين الاستقرائي والاستتباطي، وذلك حيث استقرأت كل أحاديث الفتن بتخاريج مختلفة، وشروحاتها لدى علماء علوم السنة، ثم تتبعت بالتحليل والاستباط أهم ألوان البلاغة، وملامح الإعجاز النبوي في أحاديث المصطفى عليه أنم الصلوات، والتسليم. معرفة بالراوي من كتب التب التبان 
من بلاغة النبي العدنان في دديثه عن فتن آذر الزهان فيها اتفق عليه الشيخان.

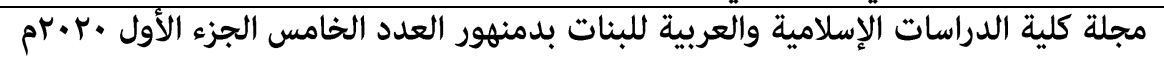
الحديث، مستخرجة معاني غريب الألفاظ من كتب اللغة وإن كانت قليلة جدا.

وقد جاء البحث في مقدمة وتمهيد، وثلاثة مباحث وخاتمة، ثم ثبت

$$
\text { المصادر والمراجع. }
$$

المقدمة وفيها هدف البحث ومنهجه وخطته.

التمهيذ وفيه نبذة عن مصطلح الفتن في اللغة وعند علماء السنة. ونبذة عن وهنه البلاغة النبوية. المبحث الأول: الإخبار بما سيكون إلى قيام الساعة من خراب الكعبة

$$
\text { ونزول الفن وتمني الموت. }
$$

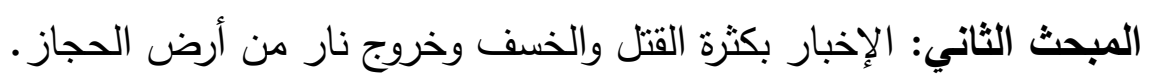
المبحث الثالث: الإخبار عن كثرة الكذابين وقرب خروج الاجال ويأجوج ومأجوج. الخاتمة وفيها أهم نتائج البحث. ثم ثبت المصادر والمراجع.

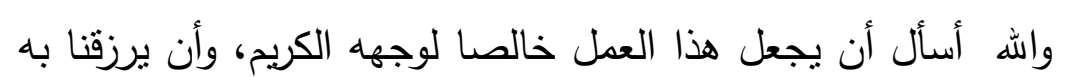
القبول في الدنيا وشفاعة الحبيب المصطفى في الآخرة. وهو حسبنا ونعم الوكيل.

\section{الباحثة}


من بلاغة النبي العدنان في دليثه عن فتن آذر الزمان فيها اتفق عليه الشيخان.

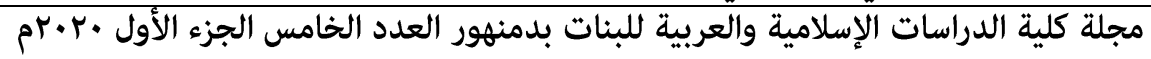

تمهيد

التعريف بالفتن:

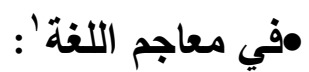

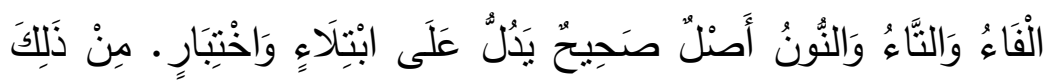

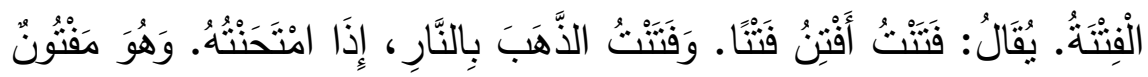

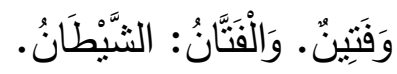

وأورد صاحب لسان العرب عن الأزهري قال:

جماع الفتنة الابتلاء، والامتحان، والاختبار، وأصلها مأخوذ من الن رهن

قولك: فنتت الفضة والذهب إذا أذبتهما بالنار ليتميز الرديء من الجيد....

والفتتة: المحنة، والمال والأولاد، والكفر ، واختلاف الناس بالآراء.

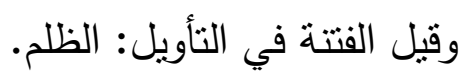

وفتتة المرأة: إذا ولهته وأحبها.

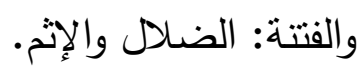

والفاتن: المضل عن الحق، والفاتن: الثيطان لأنه يضل العباد،

أو هو ما يفتن الناس بخداعه، وغروره، وتزيينه للمعاصي '؛

من هنا يتبين دوران معنى الفتتة في اللغة على معنى : الابتناء،

الإحراق، المحنة، الكفر، اختلاف الآراء، الظلم، الضلال، الإثم، إلا أنه دئه

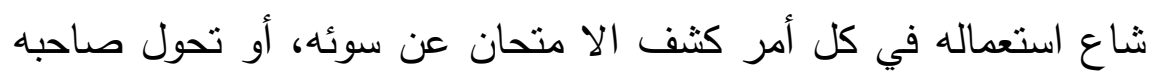
من حال إلى حال أسوأ من.

1 دعجم مقاييس اللغة لأحمد بن فارس بن زكرياء القزويني الرازي -المحقق: عبد السلام محمد هارون-

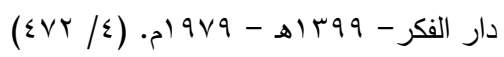

r لسان العرب لابن منظور - دار المعارف. مادة (فنت). 
من بلاغة النبي العدنان في دديثه عن فتن آذر الزهان فيها اتفق عليه الشيذان.

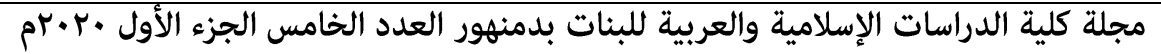

\section{•القتن كما جاءت في كتب السنة:}

وضح من كتب اللغة، سعة دائرة المعنى اللغوي لمادة فنن، وجاءت

في تراكيب اللغة تقيد أكثر من معنيين لغويين في آن واحد. وسعة اللغة وكونها حمالة لأوجه كثثرة دليل ثرائها وغزارة معانيها.

وبالنظر في كتب السنة النبوية المطهرة فقد "دارت كلمة "الفتن" على لى

معان عدة، وكثر استعمالها في الاختبار ، والابتلاء، والإثم، والكفر، والقتل،

$$
\text { والإزالة، والصرف عن الثيء. }
$$

كما اهتم علماء السنة بأمر الفتن، واعتتوا بها عناية خاصة، فأفردوا

لها في مصنفاتهم كتبا، أوردوا تحتها ما يتصل بدلائل الفتن، والجهة التي تصدر منها، وواجب المسلم نحوها، وكيفية نزول الفتن واقترابها، وكيف

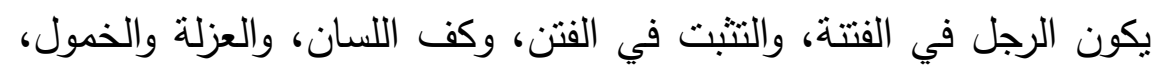

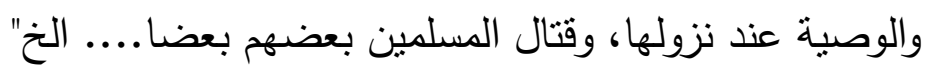

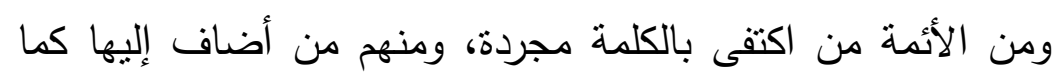

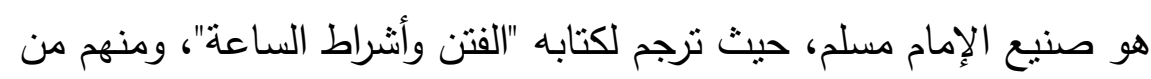

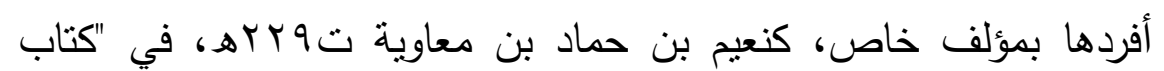

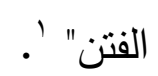

والبحث هنا تقيد بنصوص أحاديث الفتن التي اتفق عليها الثيخان، الإمام البخاري، والإمام مسلم في صحيحيهما، وقد جمعها كتاب اللؤلؤ والمرجان فيما تفق عليه الثيخان، جمع: أ.محمد فؤاد عبد الباقي، رتب ولب الإمان

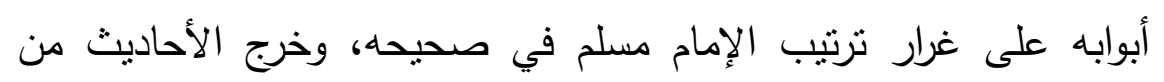

1 من فقه الفتن في ضوء السنة- د/ عبد الله شعبان - دار البشير للتقافة والعلوم- طنطا. طا - 999 ام.

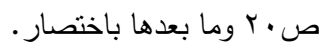


من بلاغة النبي العدنان في دلايثه عن فتن آذر الزمان فيها اتفق عليه الشيخان.

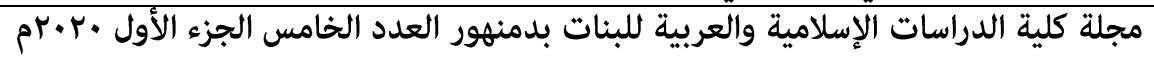

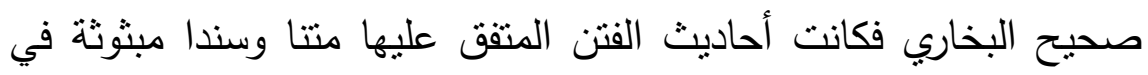
صحيح البخاري بين الأبواب، (كتاب الأنبياء- كتاب البيوع- كتاب فضائل المدينة- كتاب المناقب- كتاب الإيمان - كتاب القدر - كتاب الفتن - كتاب الحج- كتاب الجهاد)، بينما جاءت متتالية في كتاب الفتن في صحيح مسلم.

وقد قام البحث على اثثين وعشرين حديثا، ليس هم كل باب الفتن في كتاب اللؤلؤ والمرجان، ولكني تخيرت منها ما يمت لواقعنا بصلة وثثقة، لإيماني بأن الدرس البلاغي، وخاصة ما يكون متعلقا بكتاب الله أو سنة نبيه صلى الله عليه وسلم، يعالج الواقع ويلخص أسباب علله. والبيان النبوي الثريف فيه ما فيه من البلاغة والفصاحة التي جاءت في أحاديثه صلى الله عليه وسلم، فهو الطبقة العليا من البيان البشري، وإعجاز نظمه إنما هو نال لإعجاز نظم القرآن الكريم، فهما من مشكاة

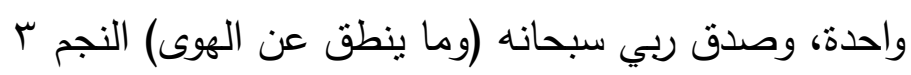
فقصاحته - صلى الله عليه وسلم - من السمْتِ الذي لا يؤخذ فيه على حقه، ولا يتعلق بأسبابه متعلق، فإن العرب وإن هذبوا الكلام وحذقوه

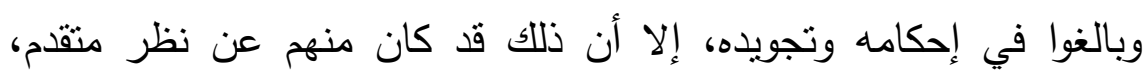
وروية مقصودة، وكان عن تكلف يُستعان له بأسباب الإجادة التي تسمو

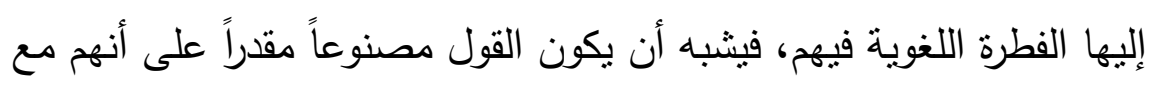

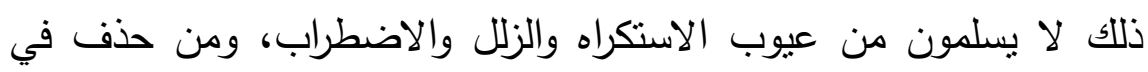
موضع إطناب، وإطناب في موضع، ومن كلمة غيرها أليقُ، ومعنى غيره

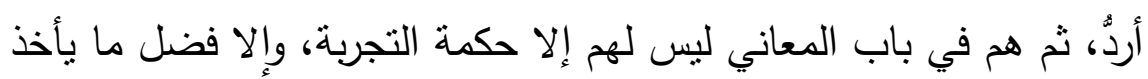
بعضهم عن بعض، قل ذلك أو كثر، والمعاني هي التي تعمر الكلام وتنتتبع ألفاظه، وبحسَبها يكون ماؤه ورونقه، وعلى مقدارها وعلى وجه ونه 
صن بلاغة النبي العدنان في دديثه عن فتن آذر الزهان فيها اتفق عليه الشيذان.

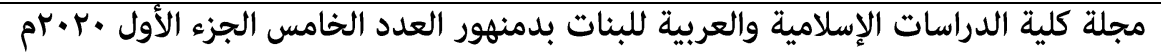

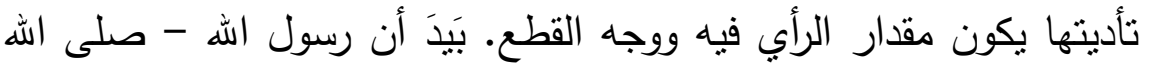
عليه وسلم -كان أفصح العرب، على أنه لا يتكلف القول، ولا يقصد إلى بلى لئه

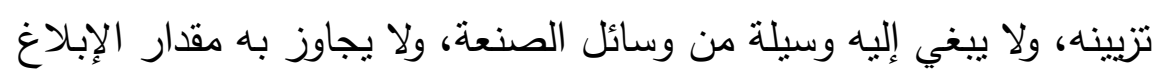
في المعنى الذي يريده، ثم لا يعرض له في ذلك سقَط ولا استكراه؛

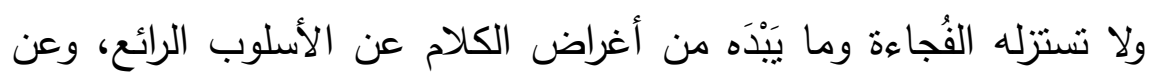
النمط الغريب والطريقة المحكمة، بحيث لا يجد النظر إلى كلامه طريقاً

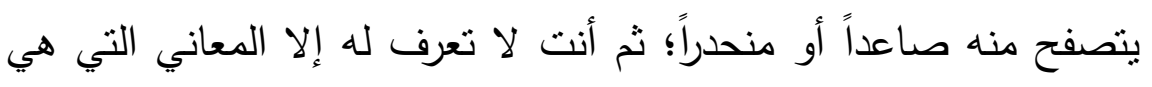
إلهام النبوة، ونتاج الحكمة، وغاية العقل، وما إلى ذلك مما يخرج به الكلام وليس فوقه مقداز إنساني من البلاغة والتسديد وبراعة القصد والمجيء في كل ذلك من وراء الغاية' . كلية

هذه هي البلاغة الإنسانية التي سجدت الأفكار لآيتها، وحسرت

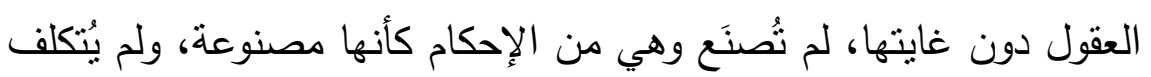
لها وهي على السهولة بعيدةً ممنوعة.

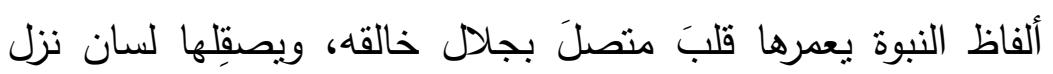
عليه القرآن بحقائقه، فهي إن لم تكن من الوحي ولكنها جاءت من سبيله وإن لم يكن لها منه دليل فقد كانت هي من دليله، مُحكمَة الفصول، حتى ليس فيها عروة مفصولة، محذوفة الفضول، منه دهن حتى ليس فيها كلمة مفصولة.

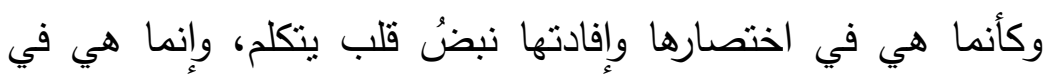
إجادتها مظهر من خواطره - صلى الله عليه وسلم - إن خرجت في لهي لهي

ا إعجاز القرآن والبلاغة النبوية لمصطفى صادق الرافعي-دار الكتاب العربي- بيروت- طم- ه . . rم.

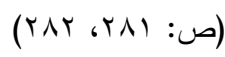


من بلاغة النبي العدنان في دايثه عن فتن آذر الزمان فيها اتفق عليه الشيخان.

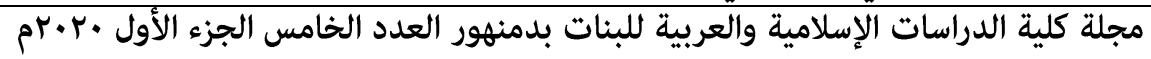

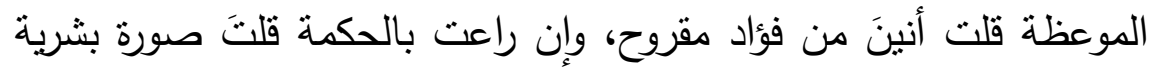

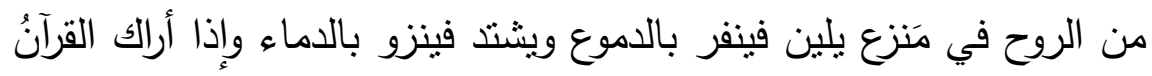

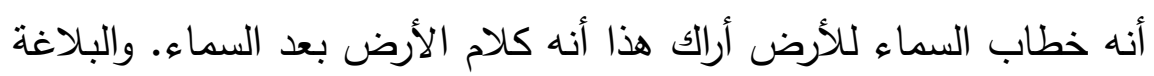

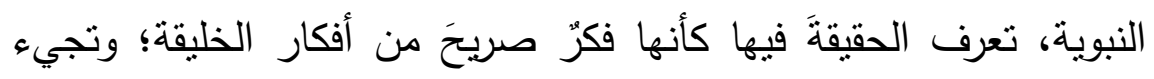
بالمجاز الغربب فترى من غرابته أنه مجاز في حقيقة. وهي من البيان في

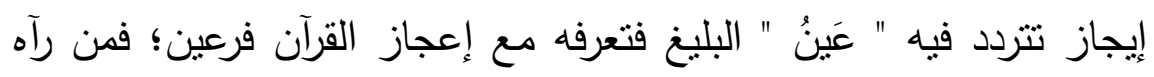

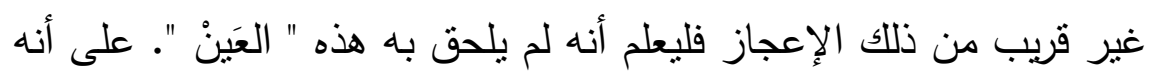
سواء في سُهولة إطماعه؛ وفي صعوبة امتتاعه؛ إن أخذ أبلغ الناس في إنهان ناحيته، لم يأخذ بناصيته، وإن أقدم على غير نظر فيه رجع مبصراً، وإن جرى في معارضته انتهى مقصراً' وكلامه هو الكلام الذي قل عدد حروفه وكثر عدد معانيه وجل عن

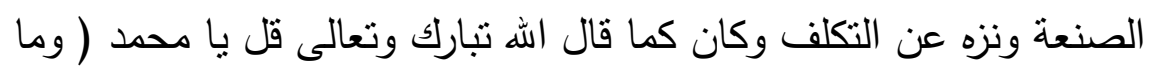

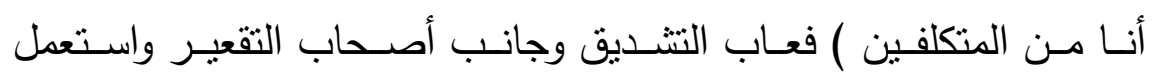
المبسوط في موضـع البسط والمقصسور في موضـع القصر وهجر الغريب الوحشي ورغب عن الهجين السوقي فلم ينطق إلا عن ميراث حكمـة ولم يتكلم إلا بكلام قد حف بالعصمة وشيد بالتأييد ويسر بالتوفيق. وهو الكلام الذي ألقى الله المحبة عليه وغشاه بالقبول وجمع له بين المهابة والحلاوة بين بالهان

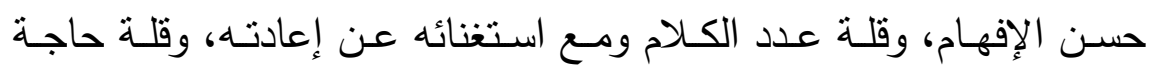

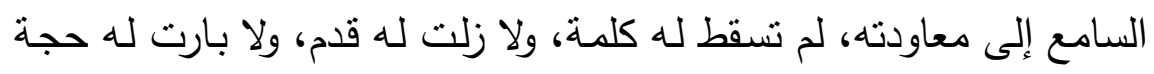

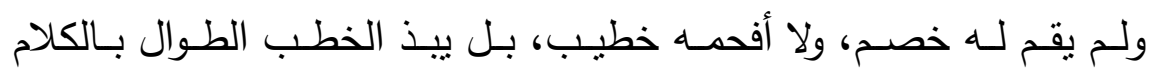

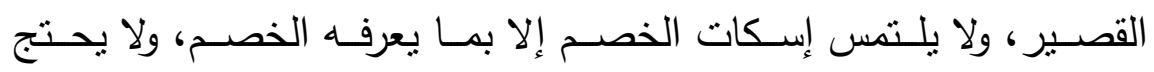


من بلاغة النبي العدنان في دديثه عن فتن آذر الزهان فيها اتفق عليه الشيخان.

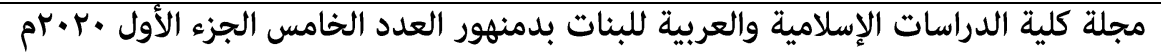

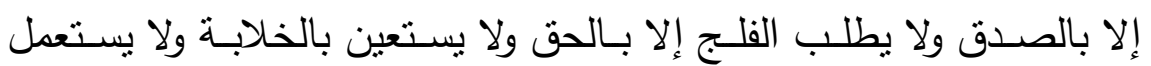
المواربة ولا يهمز ولا يلمز ولا يبطىء ولا يعجل ولا يسهب ولا يحصر ثم لم إلم وهُ

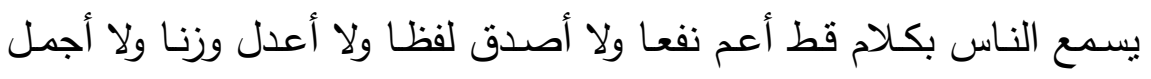
مذهبا ولا أكرم مطلبا ولا أحسن موقعا ولا أسهل مخرجا ولا أفصح عن معناه

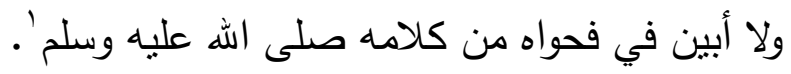

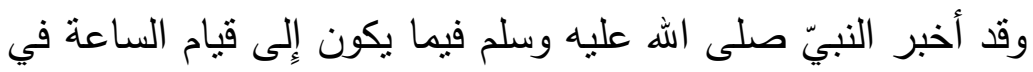
حديث طويل كما جاء في حديث حُذَيْفَةََ رضي الله عنه فَّالَ: لَقََْْ خَطَبَنَا

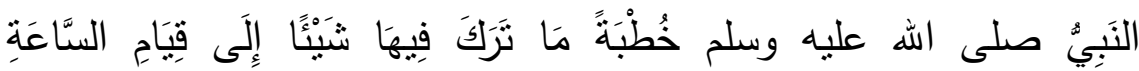

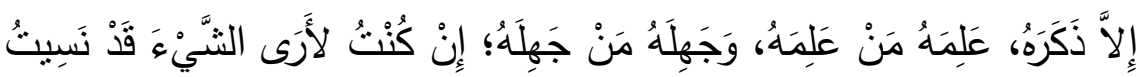

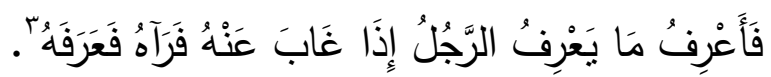

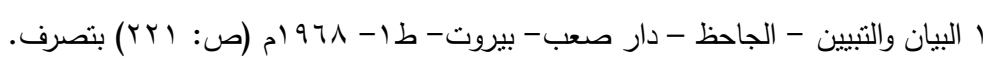

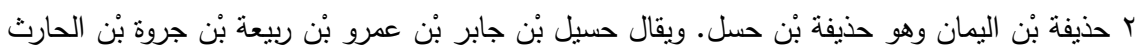

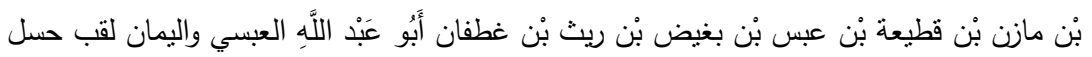

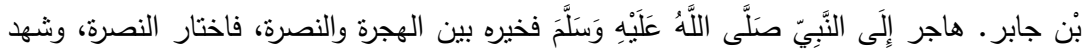

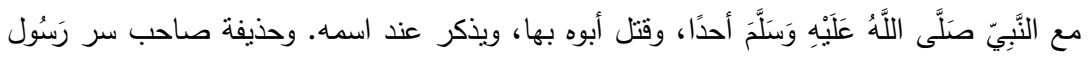

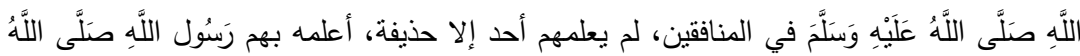

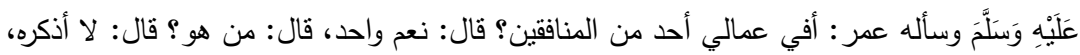

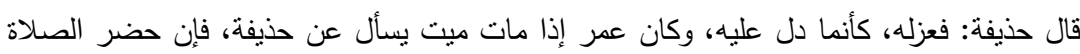

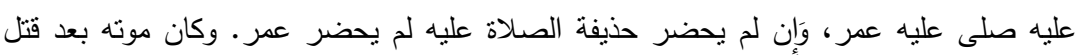

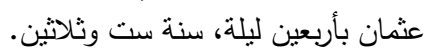

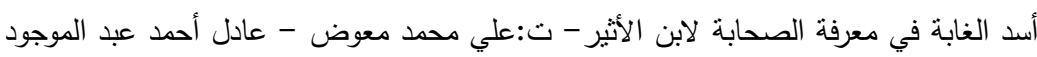

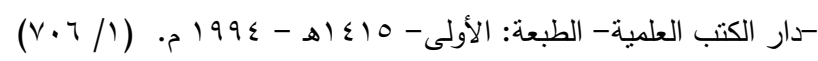

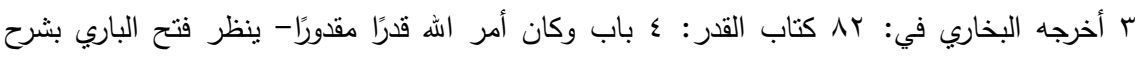

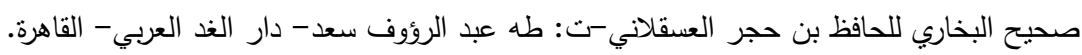
وصحيح مسلم- دار الكتب العلمية- بيروت- لبنان. الجزء الثاني- كتاب الفتن. اللؤلؤ والمرجان

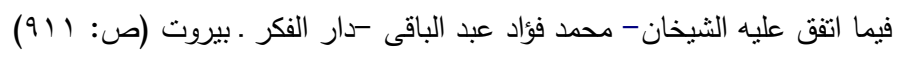


من بلاغة النبي العدنان في دليثه عن فتن آذر الزهان فيها اتفق عليه الشيخان.

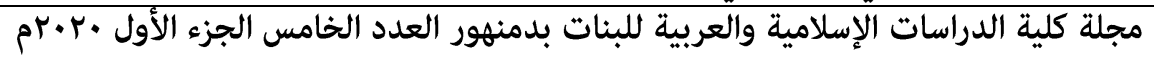

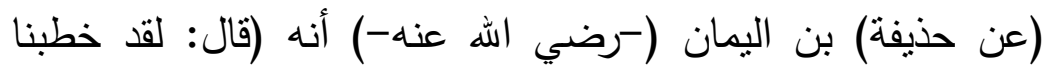

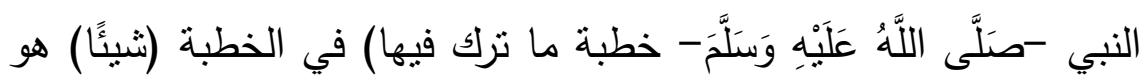
كائن من الأمور المقدرة (إلى قيام الساعة إلا ذكره علمه من علمه وجهله من جهله). ولمسلم من رواية جرير عن الأعمش حفظه من حفظه ونسيه من نسيه (إن كنت لأرى الثيء قد نسيت) بفتح همزة لأرى وحذف المفعول هن النه من نسيت ولأبي ذر عن الكثميهني نسيته ثم أتذكره (فأعرف) ولأبي ذر لإن فأعرفه (ما) وفي نسخة كما (يعرف الرجل) أب الرجل فحذف المفعول وفي

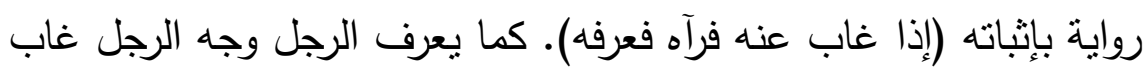
عنه ثم رآه فعرفه أي الذي كان غاب عنه فنسي صورته ثم إذا رآه عرفه ا. هذا الحديث الذي جاء بلفظ الصحابي حذيفة بن اليمان يعتبر رأس

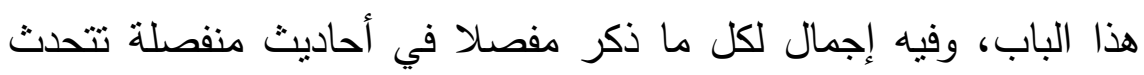
عن أنواع شتى من الفنن، ستقع إلى قيام الساعة. ويلاحظ استعمال الصحابي الجليل لأسلوب القصر، الذي أراد به إبه حصر كل الفنن في كل ما ذكر النبي صلى الله عليه وسلم، ولعل عدم تفصيلها ذكر الصحابي الجليل علته، فإنه صلى اله عليه وسلم لهول ما ذكر ، وعى كل قدرما استوعب عقله، هذه الأمور العظام، والأحداث الجسام.

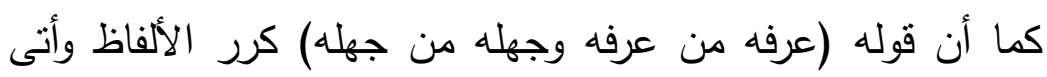

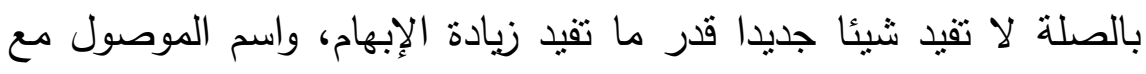
صلته هنا ذريعة لتعظيم الموصوف به، أو ذربعة للتعريض، بالمنزلة

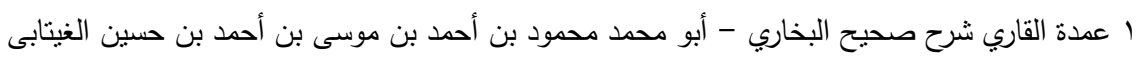

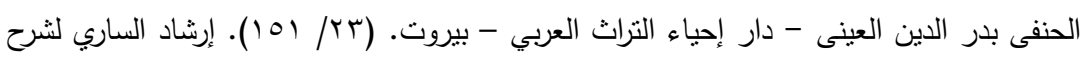

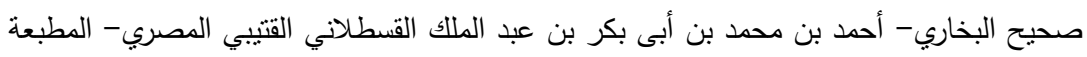

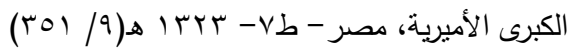




\section{صن بلاغة النبي العدنان في دديثه عن فتن آذر الزمان فيها اتفق عليه الشيخان.}

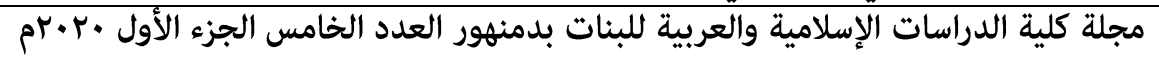

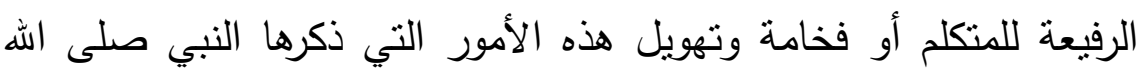

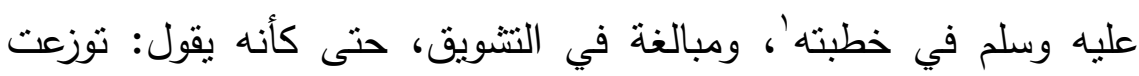

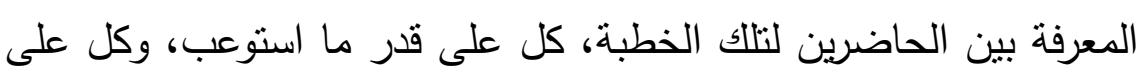
قدر ما تحفظ ذاكرته، وإن كان حذيفة أكثرهم حفظا في تلك الخطبة. والأحاديث التالية - محل البحث - ستوضح شيئا من ثلك الأحداث

$$
\text { التي أجمل الحديث عنها في هذا الحديث الثريف. }
$$

ا ينظر البلاغة العربية أسسها وعلومها وفنونها لعبد الرحمن حسن حبنكة الميداني- دار القلم- دمشق-

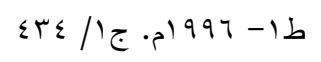


من بلاغة النبي العدنان في دايثه عن فتن آذر الزهان فيها اتفق عليه الشيخان.

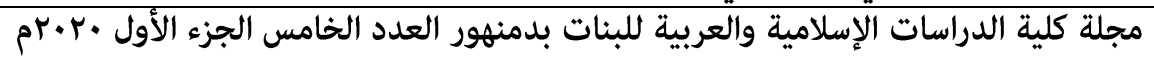

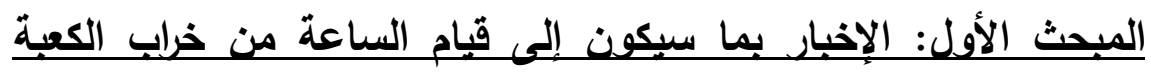

ونزول القتن وتمني الموت الاون

أولا: إخبار النبيّ صلى الله عليه وسلم فيما يكون إلِى قيّم الساعة

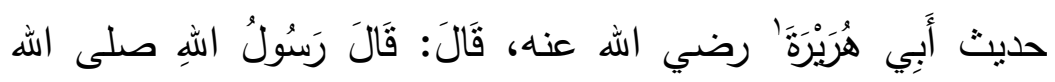

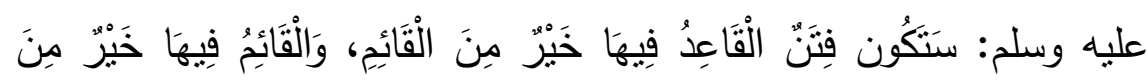

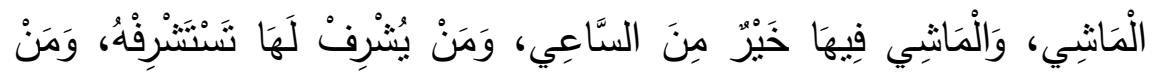

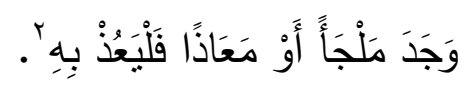
التحليل البلاغي والشرح:

(ستكون فنن) جمع فتنة، والمراد الاختلاف الواقع بين أهل الإسلام

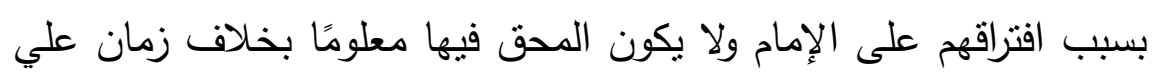
ومعاوية (القاعد فيها خير من القائم، والقائم فيها خير من الماشي، والماشي لئي فيها خير من الساعي) أب: القاعد في زمانها عنها، والمراد بالقائم الذي في فئي لا يستشرفها وبالماشي من يمشي في أسبابه لأمر سواها فربما يقع بسبب الهاني

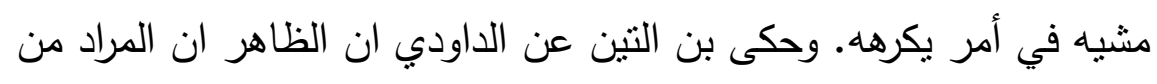

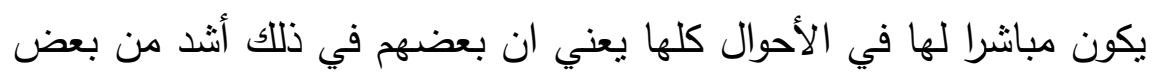

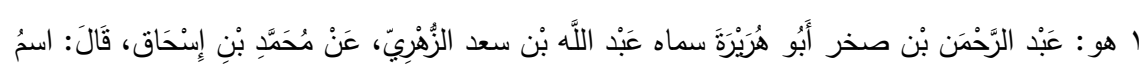

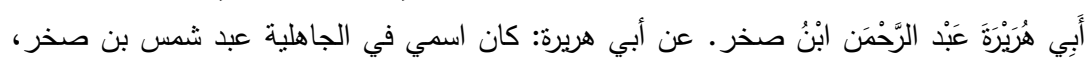

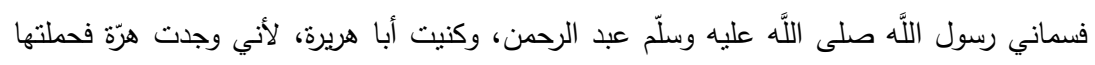

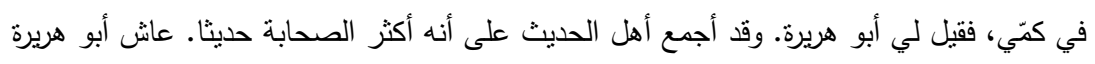

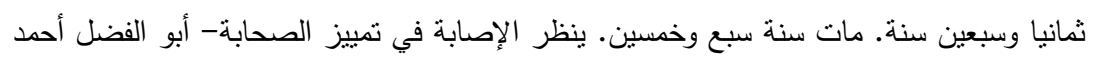

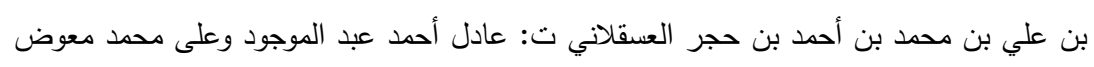

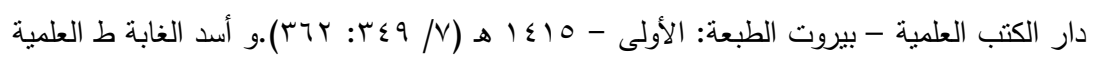

( $($ \& $0 V / r)$

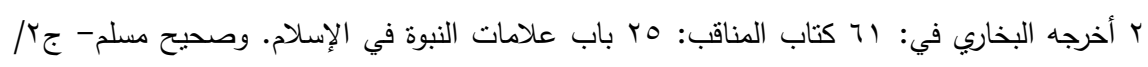

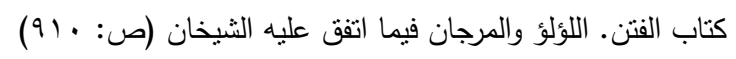


صن بلاغة النبي العدنان في دديثه عن فتن آذر الزهان فيها اتفق عليه الشيذان.

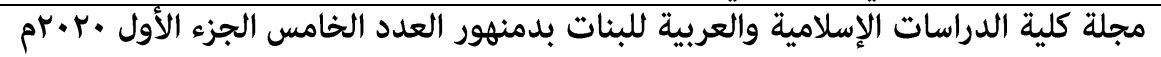
فأعلاهم في ذلك الساعي فيها بحيث يكون سببا لإثارتها ثم من يكون قائما بأسبابها وهو الماشي ثم من يكون مباشرا لها وهو القائم ثم من يكون مع لهم النظارة ولا يقاتل وهو القاعد ثم من يكون مجنتبا لها ولا يباشر ولا ينظر وهو المضطجع اليقظان ثم من لا يقع منه شيء من ذلك ولكنه راض وهو النائم والمراد بالأفضلية في هذه الخيرية من يكون أقل شرا ممن فوقه على ليع من دهن التقصيل المذكور • قال النووي: معناه بيان عظم خطرها والحث على تجنبها والهرب منها ومن التسبب في شيء منها لأن سببها وشرها وفتتتها تكون على حسب التعلق بها، قال التوربشتي: أي من تطلع لها دعته إلى الوقوع

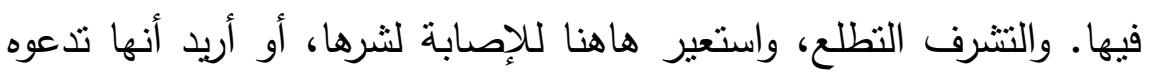
إلى زيادة النظر إليها، وقيل: إنه من استترفت الثيء إذا علوته يريد من

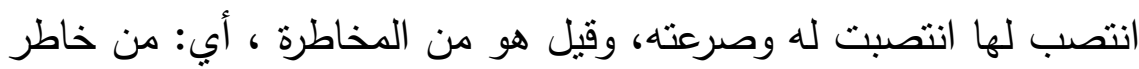
بنفسه فيها أهلكته. قال الطيبي: لعل الوجه الثالث أولى لما يظهر منه من من النه معنى اللام في لها وعليه كلام الفائق وهو قوله أي من غالبها غلبته. (ومن وجد ملجأ) أي عاصمًا أو موضعًا يلتجئ إليه ويعتزل فيه (أو) فال: (معاذًا) شك من الراوي وهما بمعنى (فليعذ به) أي ليعتزل فيه ليسلم من شر الفتنة

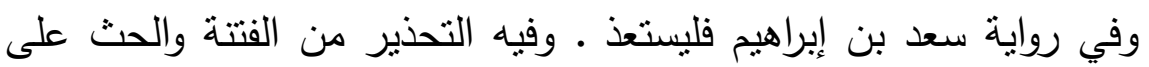
اجتتاب الدخول فيها وأن شرها يكون بحسب التعلق بها، والمراد بالفتتة ما ينشأ عن الاختلاف في طلب الملك حيث لا يعلم المحق من المبطل '.

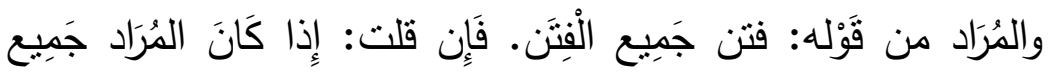

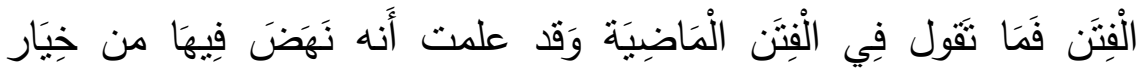

ا إرشاد الساري لشرح صحيح البخاري للقسطلاني (T/ به). فتح الباري شرح صحيح البخاري- لأحمد

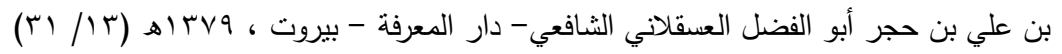




\section{صن بلاغة النبي العدنان في دايثه عن فتن آخر الزهان فيها اتفق عليه الشيخان.}

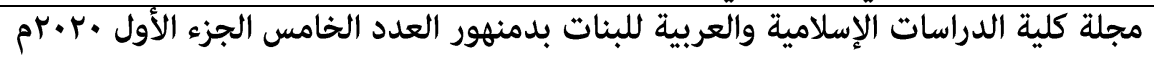

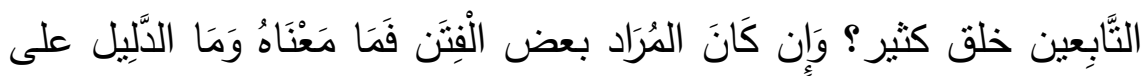

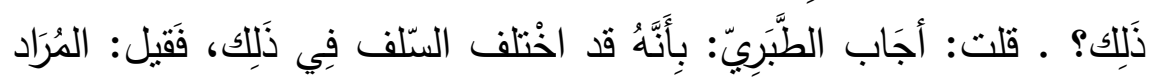

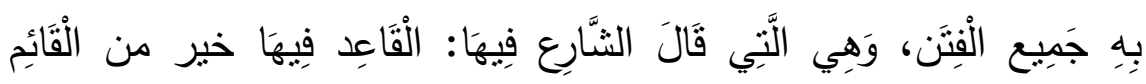

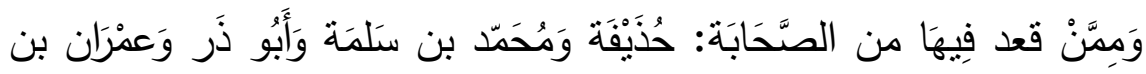

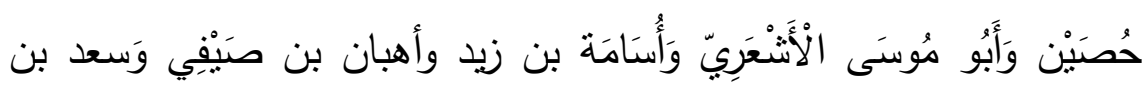

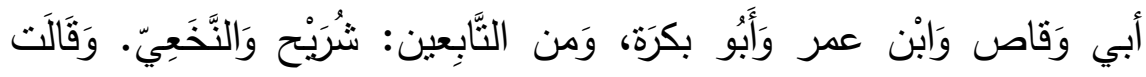

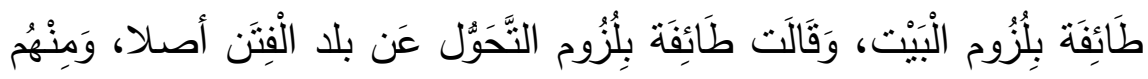

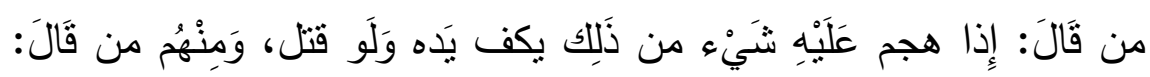

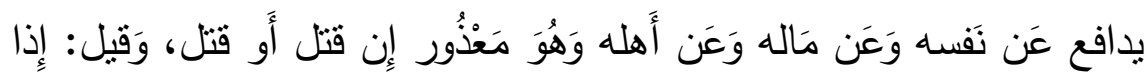

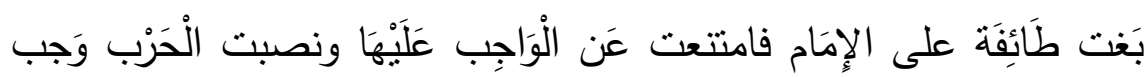

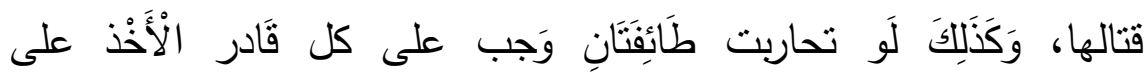

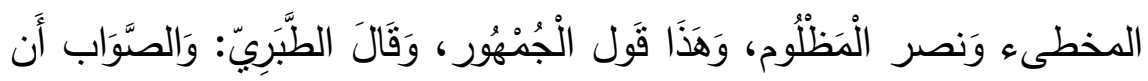

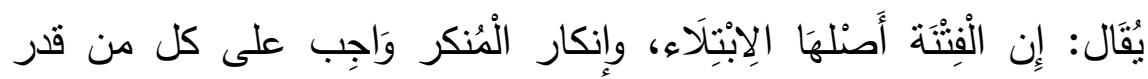

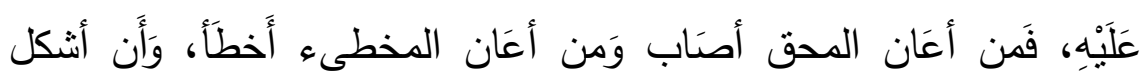

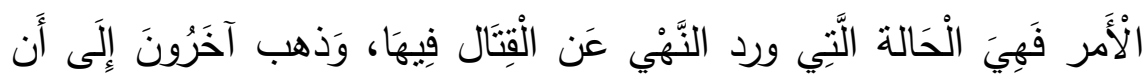

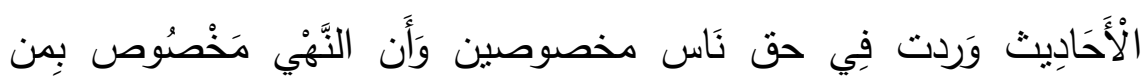

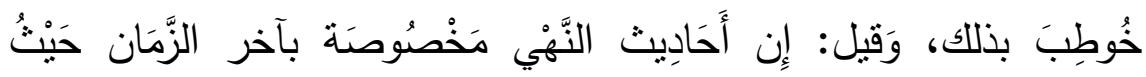

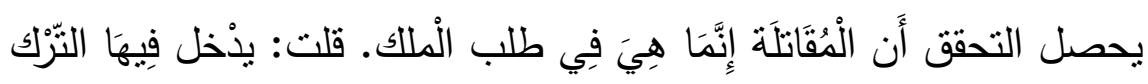

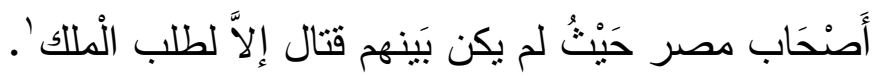

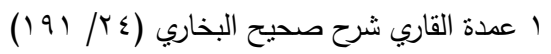


صن بلاغة النبي العدنان في دديثه عن فتن آذر الزهان فيها اتفق عليه الشيذان.

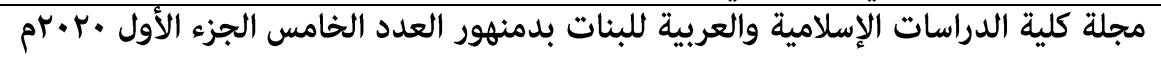

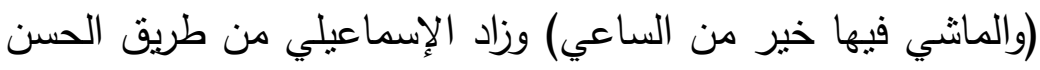

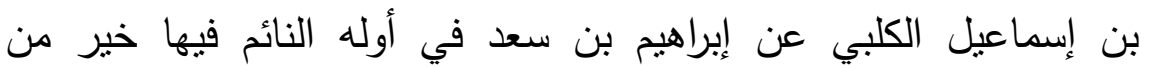
اليقظان واليقظان فيها خير من القاعد.

والحسن بن إسماعيل وثقه النسائي وهو من شيوخه وعند أحمد وأبي

داود من حديث ابن مسعود النائم فيها خير من المضطجع وهو المراد باليقظان في الرواية السابقة وفيه والماشي فيها خير من الراكب والمراد بالأفضلية في هذه الخيرية من يكون أقل شرًا ممن فوقه على التقصيل

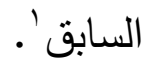

والملاحظ من شرح الحديث أن النبي الكريم صلى الله عليه وسلم قد أبدع في تصوير كيفية التعامل مع الفتن حين حدوثها، فبدأ الحديث بقوله

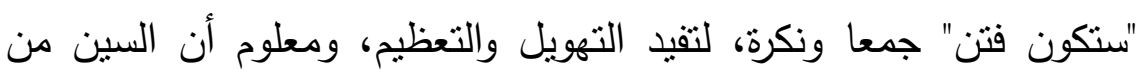
حروف التأكيد التي تدخل على الفعل المضارع فتخلصه للاستقبال، "والسين

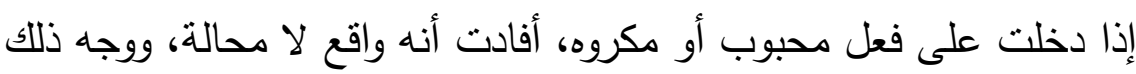
أنها تفيد الوعد أو الوعيد بحصول الفعل، فذخولها على ما يفيد الوعد

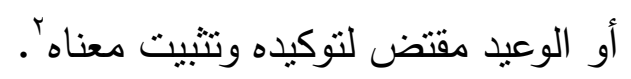

ثم تعبيره بـ (القاعد- القائم- الماشي - الساعي) وهو ترق في تصوير مجابهة الفتن، فلم يقل ابتعد عنها، لأن الأمور نسبية، وقد يختلط الأمر على كثثرين، ولكنه بين درجة تفاعل من بعاصر الفنن وصوره بهذه الهيئات الجسمانية، ليتضح لكل راء، أين هو من الفتن وكيف يمكنه الابتعاد عنها قدر إمكانه.

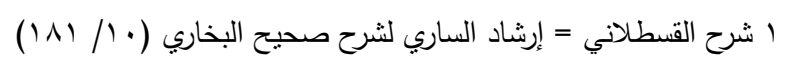

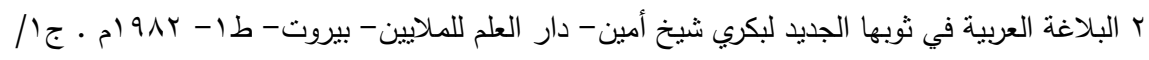




\section{صن بلاغة النبي العدنان في دايثه عن فتن آخر الزمان فيها اتفق عليه الشيخان.}

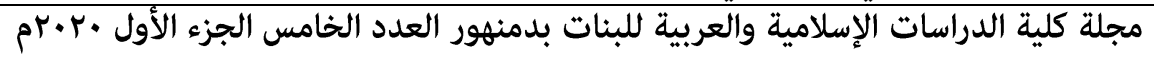

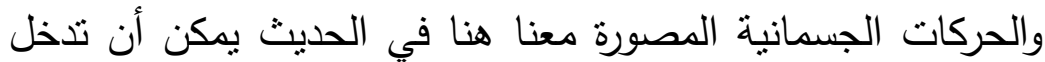
في مجال الطباق، الذي هو زينة معنوية تحسن الأسلوب وتوضح صورته، لاعنماد الذهن على سهولة تصور الثيء بذكر ضده.

ثم الشرط وزيادة مبنى الفعل في قوله "تشتشرفه" لبدل على أن مجرد

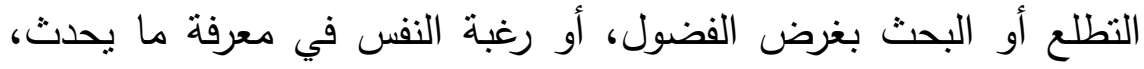
تجعل الفتن هي من تطلب الشخص ليكون في غمارها، وهو تعبير نبوي بليغ، عليم بدخائل النفس البشرية، مقدر لما ستغالبه إن كانت في هذا

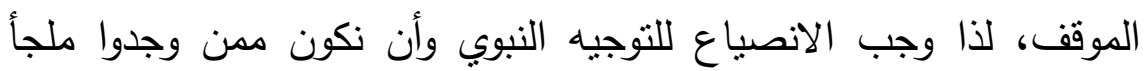

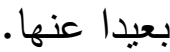

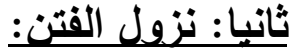

ا-حديث أُسَامَةَ' رضي الله عنه، قَالَ: أَثْرَفَْ النَّبَيُّ صلى الله عليه

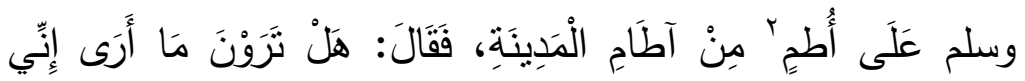

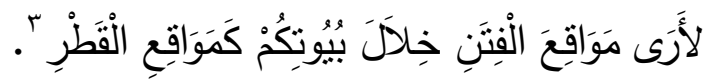

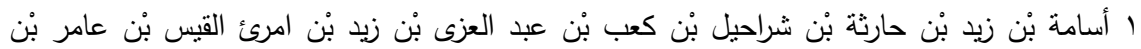

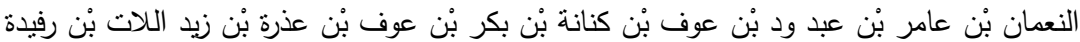

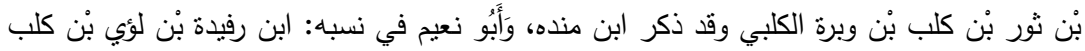

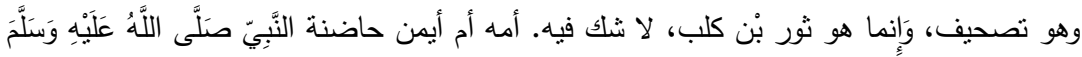

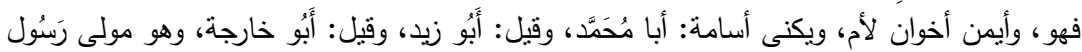

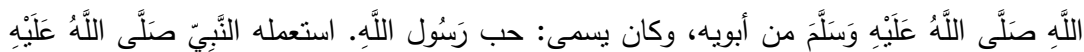

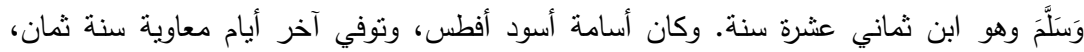

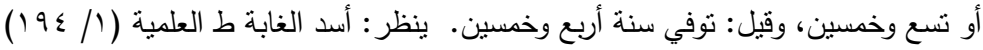

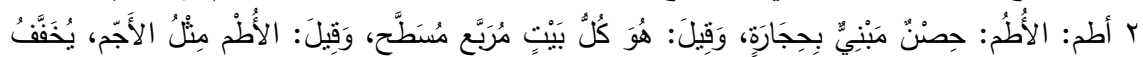

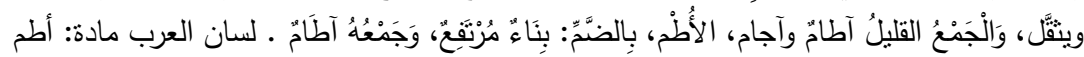

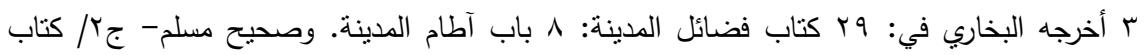
الفتن. اللؤلؤ والمرجان فيما اتفق عليه الثيخان (ص: 9 ـ9 9). القطر : 
صن بلاغة النبي العدنان في دديثه عن فتن آذر الزهان فيها اتفق عليه الشيذان.

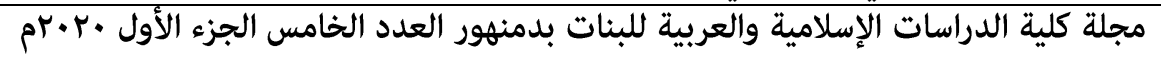

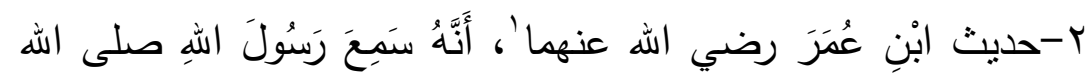

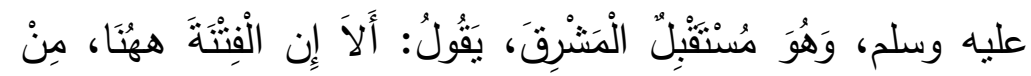

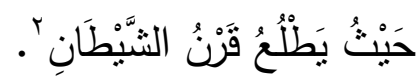

\section{التحليل البلاغي والثرح:}

قوله (أنشرف) أَي: نظر من مَكَان مُرْتَعْ. قَوَّله: (مواقع الْفِتَن) أَبي:

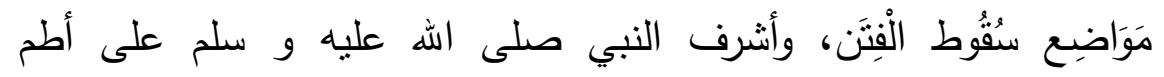

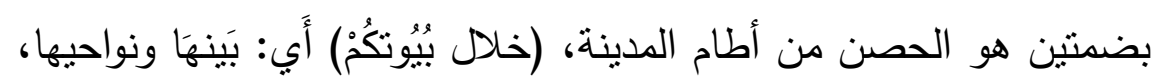

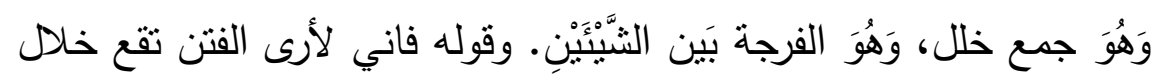

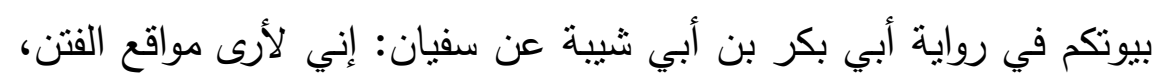

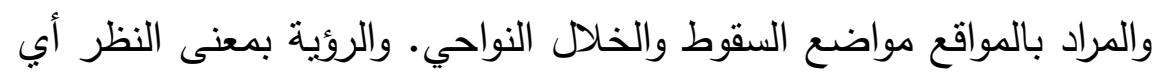

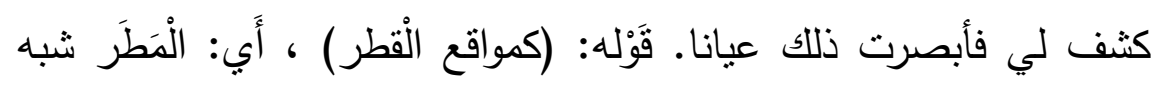

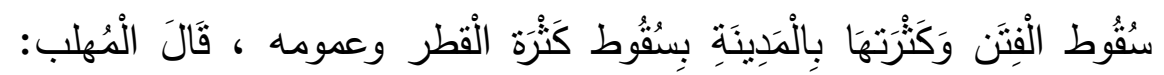

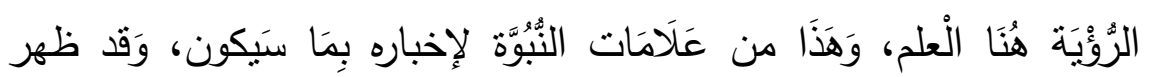

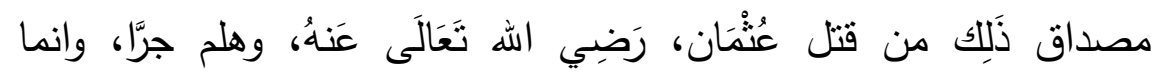
اختصت المدينة بذلك لأن قتل عثمان رضي الله عنه كان بها ثم انتشرت

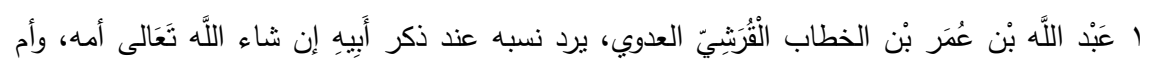

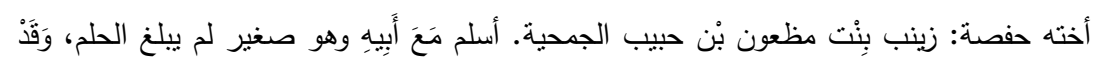

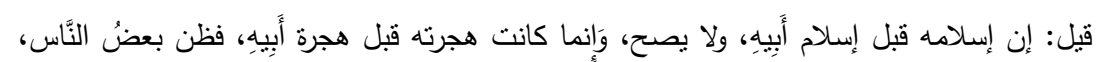

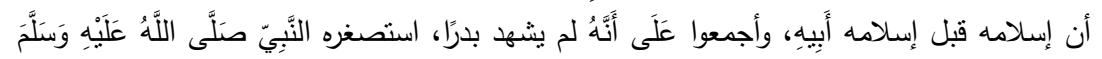

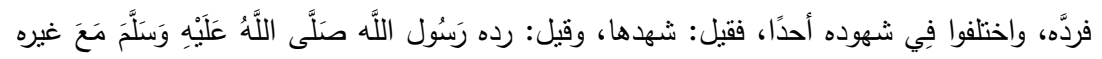

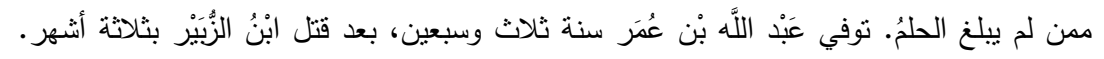

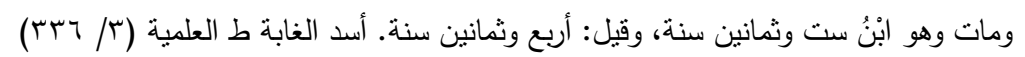

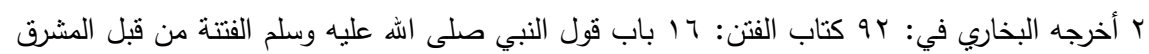

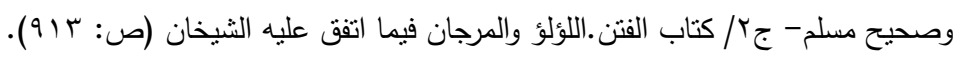


من بلاغة النبي العدنان في دلايثه عن فتن آذر الزمان فيها اتفق عليه الشيخان.

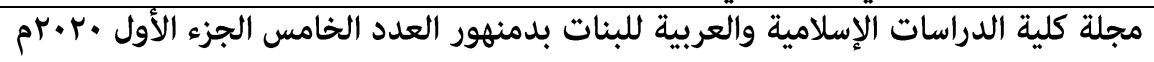

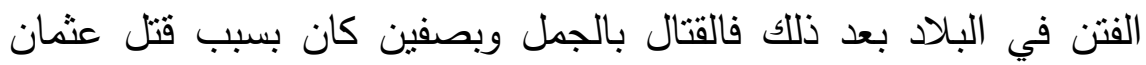
والقتال بالنهروان كان بسبب التحكيم بصفين وكل قتال وقع في ذلك العصر إنما تولا عن شيء من ذللك أو عن شيء نولا عنه ثم إن قتل عثمان كان

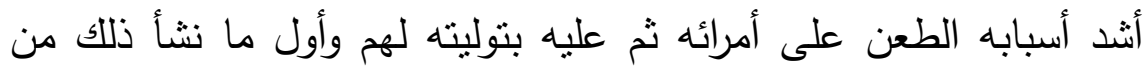
العراق وهي من جهة المشرق، كما في والحديث الثاني: : أَلاً إِن الْفِنْنَة

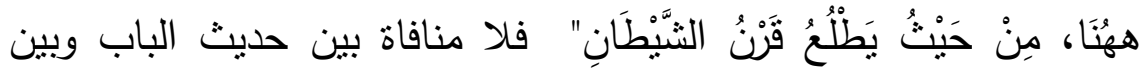
الحديث الآتي ان الفتتة من قبل المشرق وحسن التشبيه بالمطر لإرادة التعميم لأنه إذا وقع في أرض معينة عمها ولو في بعض جهاتها' .

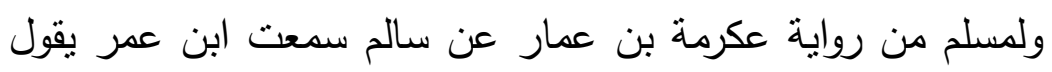

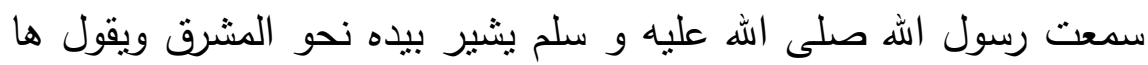

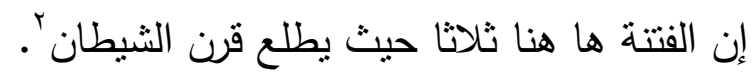
وقال الخطابي: نجد من جهة المشرق، ومن كان بالمدينة كان نجده بادية العراق ونواحيها، وهي مشرق أهل المدينة؟ّ. والملاحظ في البيان النبوي في هذين الحديثين استهال النبي صلى الله عليه وسلم الحديث الأول بالاستقهام والثاني بألا الاستفتاحية، والاستفهام أسلوب إنثائي يحفز الذهن، ويثير عقل المتلقي لرغبته في علم ما يجهل، والسؤال في الحديث سؤال لاينتظر جوابه، فهو سؤال تحضيض وتحفيز وشد انتباه لما سيلقى من خبر وما سيعلن من بيان.

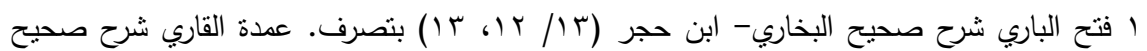

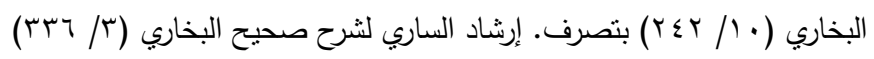

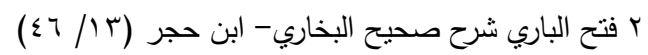

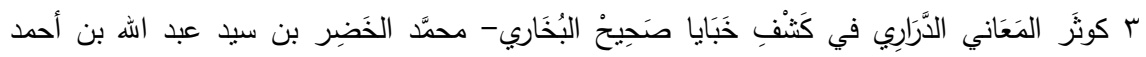

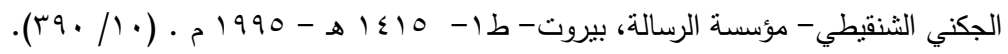


من بلاغة النبي العدنان في دديثه عن فتن آذر الزهان فيها اتفق عليه الشيخان.

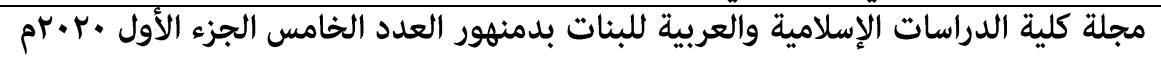

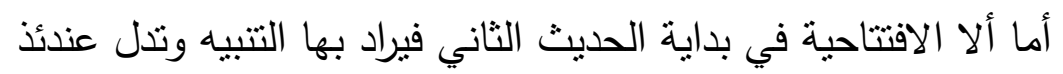
على تحقق ما بعدها، ومن هنا تأتي دلالتها على معنى التأكيد، فهي

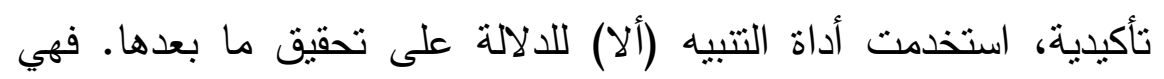

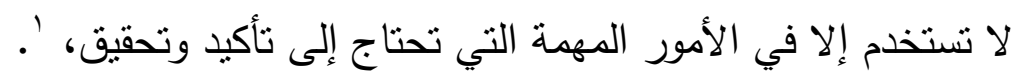
وهذا الخبر (ألا إن الفتتة ههنا) خبر غريب يستحق أن يحشد له كل إله أنواع التأكيد، وبطابق الكلام مقتضى حال المخاطبين، فمع العلم بأنهم

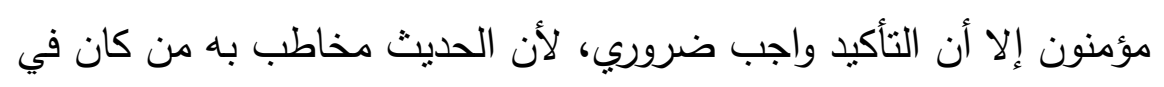
مجلس النبي صلى الله عليه وسلم، ومخاطب به من جاء بعده. وبتقاوت

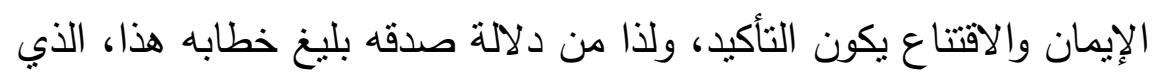

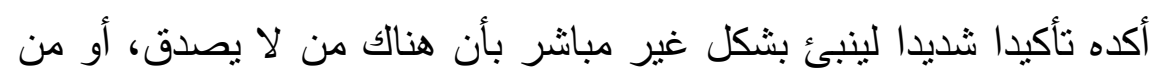
لم يتعظ، وسيقع في هذه الفتتة خلق كثيرون، وقد حدث فعلا.

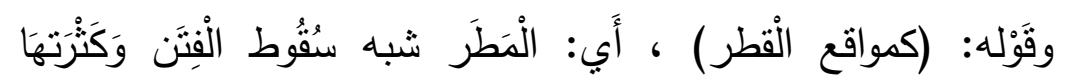

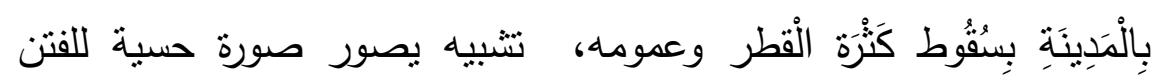

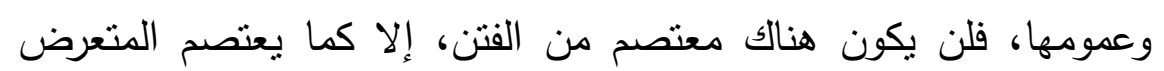
للقطر من مطر السماء إن وجد ملجأ واتخذ معزلا.

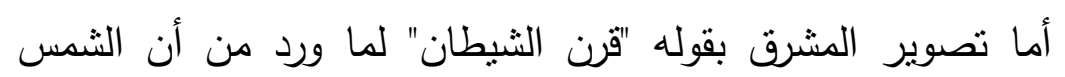
تشرق بين قرني شيطان، لذا نهي عن الصلاة وقت طلوعها.

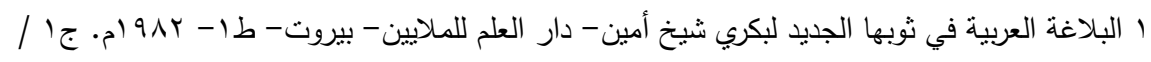

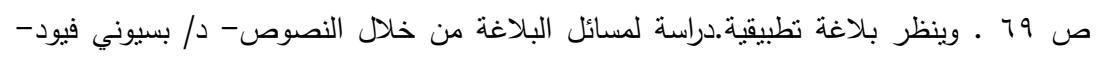

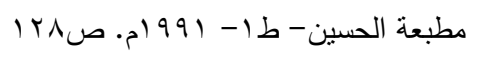


من بلاغة النبي العدنان في دليثه عن فتن آنر الزمان فيها اتفق عليه الشيخان.

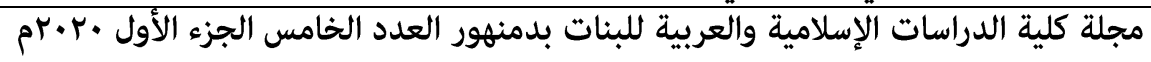

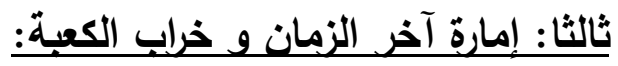

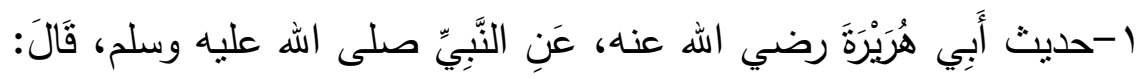

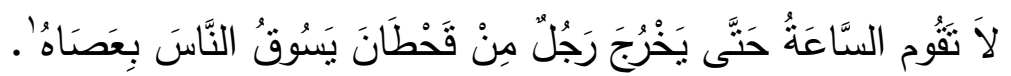

التحليل البلاغي والشرح: لأيل

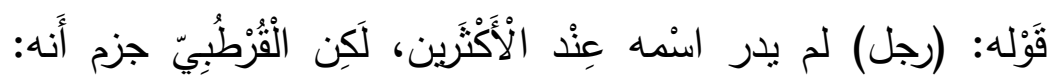

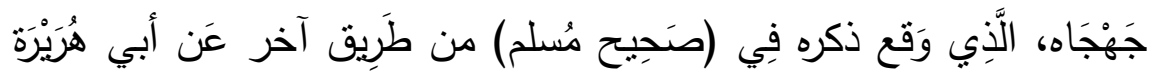

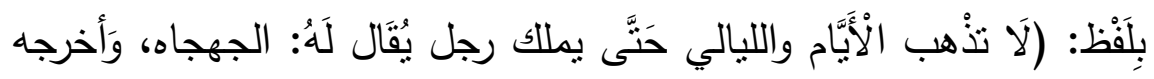
عقيب حَدِيث القحطاني. قَوَله: (يَسُوق النَّاس بعصاه) كِنَايَة عَن نسخير النَّاس واسترعائهم كسوق الرَّاعِي الْغنم بعصاه، وَفِي (النَّْضِيَح) : حَدِيث

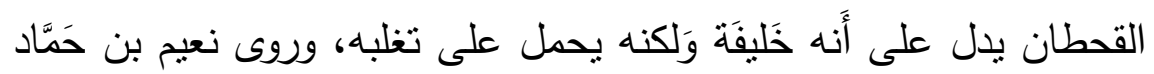

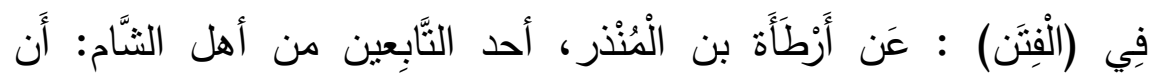

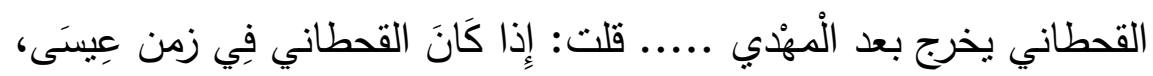

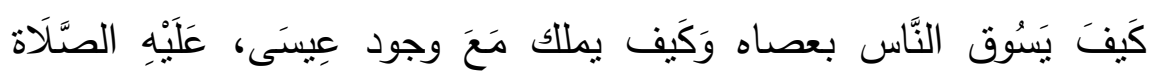

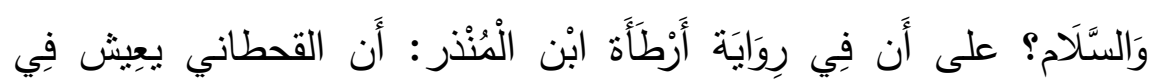

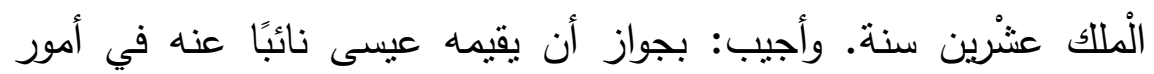
مهمة عامة.

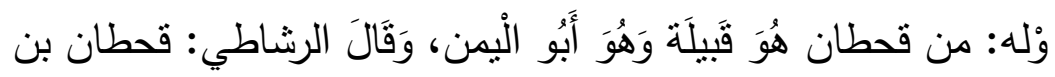

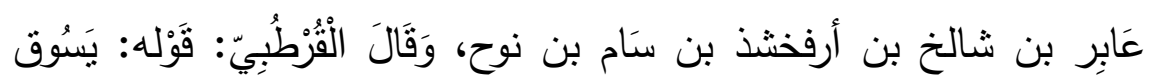

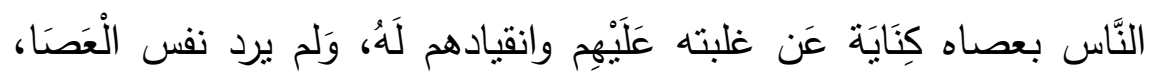

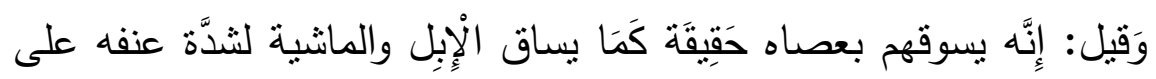

ا أخرجه البخاري في: اج كتاب المناقب: V باب ذكر قحطان وصحيح مسلم- جr/ كتاب الفنت.اللؤلؤ

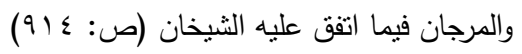




\section{صن بلاغة النبي العدنان في دديثه عن فتن آذر الزمان فيها اتفق عليه الشيخان.}

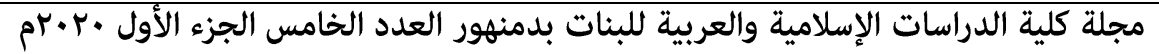
النَّاس، ومطابقة الحديث للترجمة من حيث إن سوق القحطاني الناس إنما هو في تغير الزمان وتبدّل أحوال الإسلام لأن هذا الرجل ليس من قريش إن لنش الذين فيهم الخلافة فهو من فتن الزمان وتبدّل الأحكام. '. وتعبير النبي صلى الله عليه وسلم بقوله "لا ثقوم الساعة حتى ...." ورد في مواطن كثيرة تخبر عما سيحدث بين يدي الساعة، وهو تعبير يحمل من التأكيد الكثير ، إذ نفى قيام الساعة مستقبلا كما يفيد الفعل المضارع المتصل ب"الا" التي تفيد نفي الحال، حتى تحدث هذه الأمور المتحدث عنها، والتي من بينها هنا، إمارة رجل من قحطان اختلف شراح الحديث في تحديد من هو على جهة القطع، ولكنه أوشك أن يكون أميرا على العرب، يتغلب عليهم ويكون سيدا مطاعا فيهم، كما عبرت الكناية عن هذا المعنى من الغلبة والقوة والسيطرة عليهم بقوله "يسوق الناس بعصاه" كناية عن صفة القوة التي مكنته من إمارته، وثبتت سلطانه، حتى حكم عشرين سنة كما أول وله ونه ذلك بعض شراح الحديث. ץ-حديث أَبِي هُرَبْرَة رضي الله عنه، عَنِ النَّبِِّ صلى الله عليه وسلم، قَالَ:

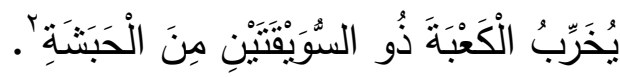

\section{التحليل البلاغي والثرح:}

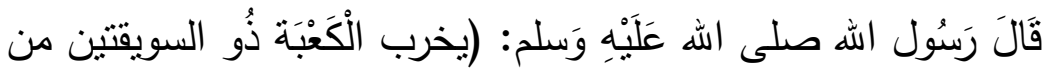

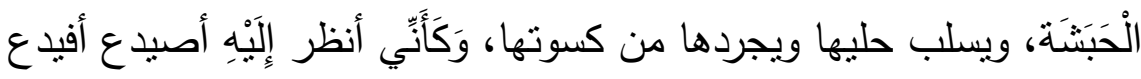

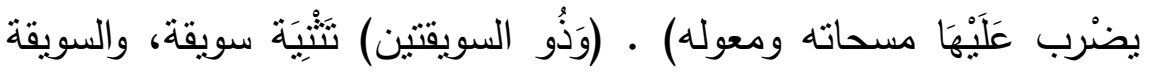

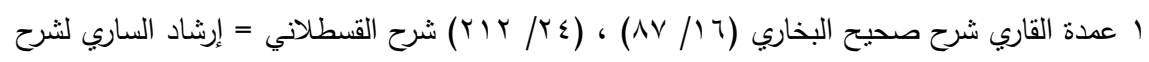

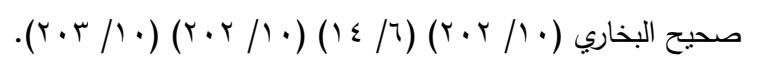

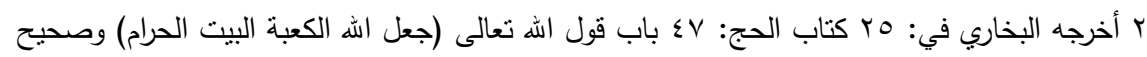

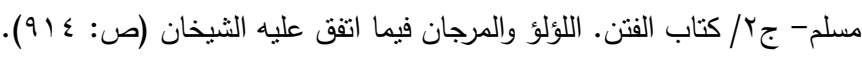


من بلاغة النبي العدنان في دايثه عن فتن آذر الزمان فيها اتفق عليه الشيذان.

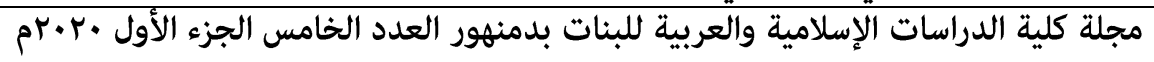

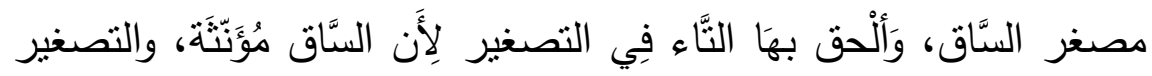

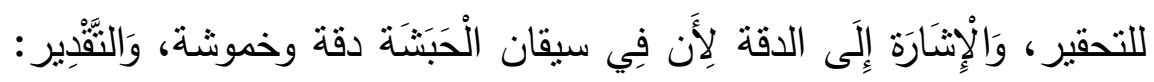

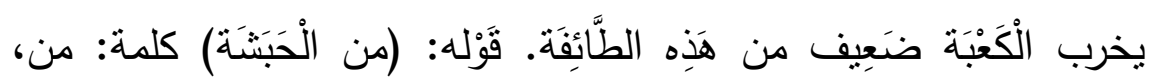

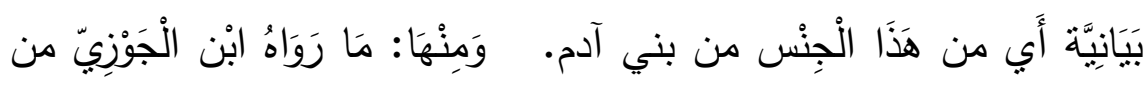

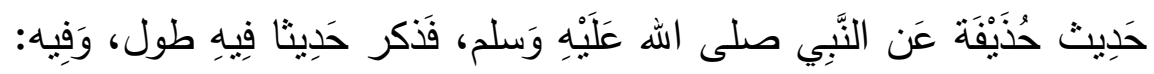

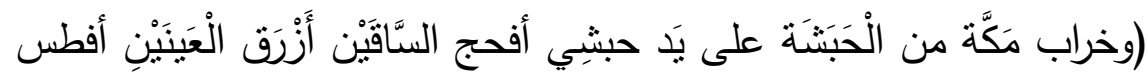

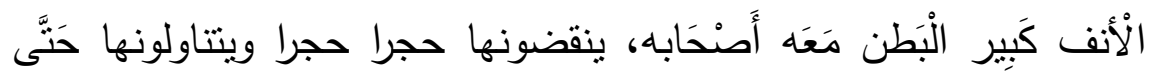

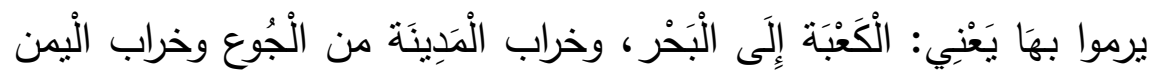

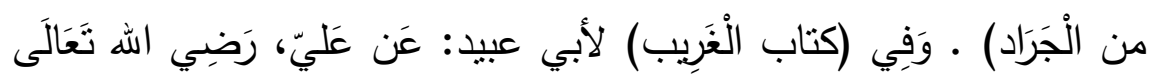

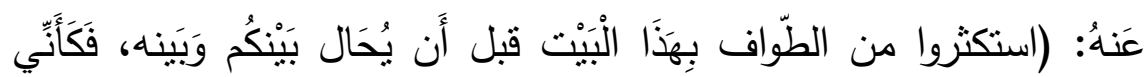

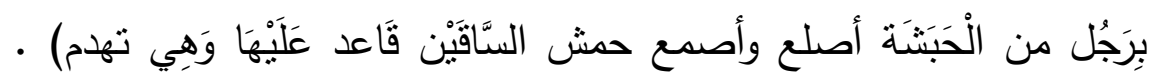

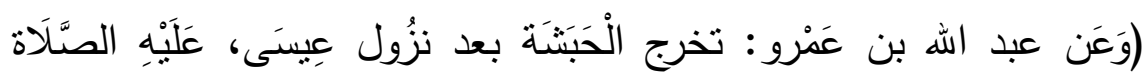

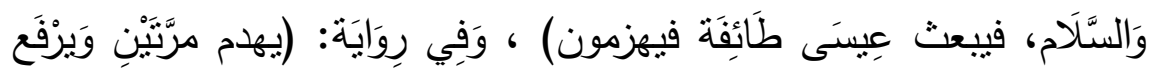

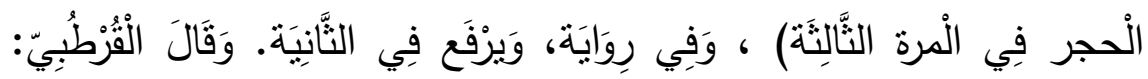

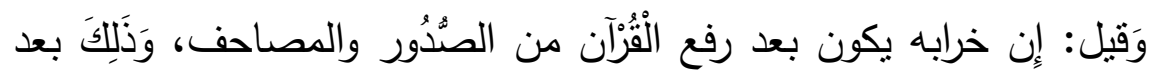

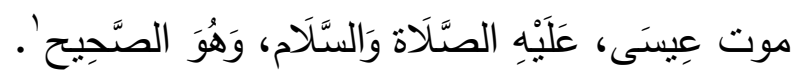

ويلاحظ تعبير النبي الكريم بالفعل المضارع لإرادة تصوير الحدث

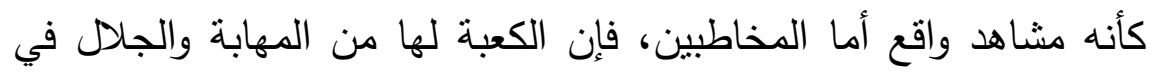
النفوس ما يعظم لدى المسلم خرابها، ولكنها سيقع ذالك التخريب قرب نهاية الزمان، وكما ذكر شراح الحديث ستخرب أكثر من مرة ولكن في الثانية

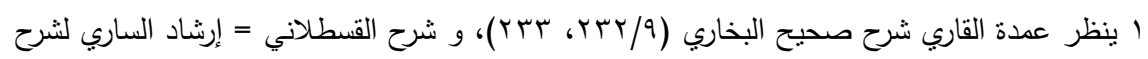

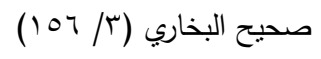




\section{صن بلاغة النبي العدنان في دلديثه عن فتن آذر الزمان فيها اتفق عليه الشيذان.}

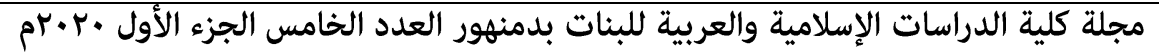

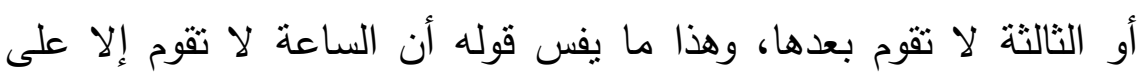

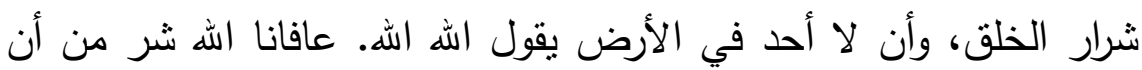
ندرك هذا الزمان.

وعلى عكس الحديث السابق الذي حثد فيه من أدوات التأكيد الكثثير

نجد الخبر هنا مجردا من أي تأكيد، وهو خطاب لمؤمن ذي يقين بأن أخبار النبي كلها صادقة، أدرك المؤمن وقت حدوثها وصدقها رأي عين، أو آمن بها وأيقن بحدوثها كما أمن بالغيبيات من ورائها وقيام الساعة.

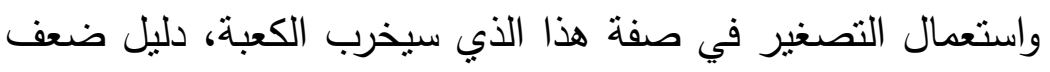
وانحطاط لحال المسلمين وقتئذ، إذ يستطيع منل هذا أن يتسلط على بيت الله الحرام ويهدمه. لإيعا: تمني الموت

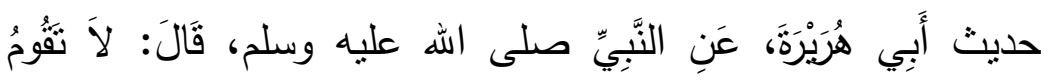

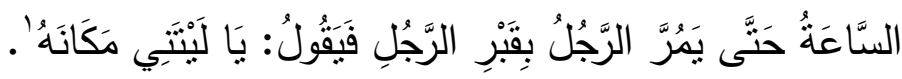

\section{التحليل البلاغي والثرح:}

(لا تقوم الساعة حتى يمر الرجل بقبر الرجل فيقول يا ليتتي مكانه) أي كنت ميتًا وذلك عند ظهور الفتن وخوف ذهاب الدين لغلبة الباطل وأهله

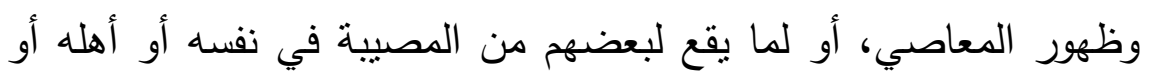

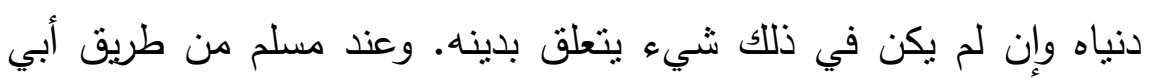

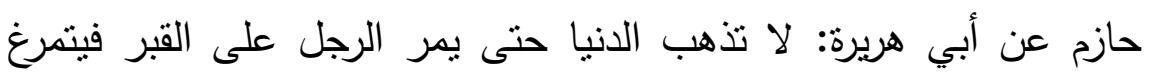
عليه ويقول: يا ليتتي مكان صاحب هذا القبر وليس به الدين إلإ البلاء

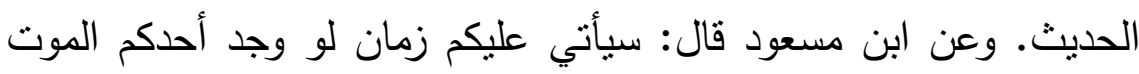

ا أخرجه البخاري في: Yو كتاب الفتن: بr باب لا تقوم الساعة حتى يغبط أهل القبور وصحيح مسلم-

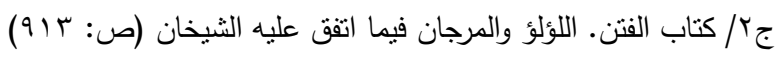


من بلاغة النبي العدنان في دلايثه عن فتن آذر الزمان فيها اتفق عليه الشيخان.

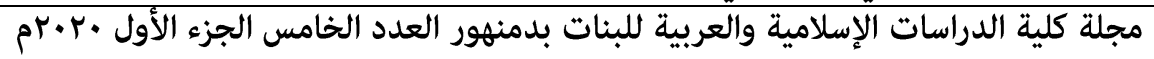

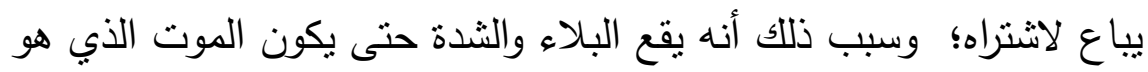

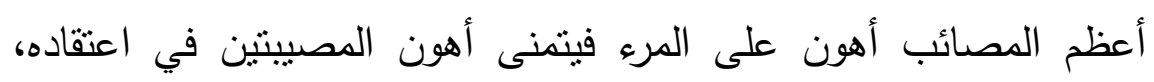
وذكر الرجل في الحديث للغالب وإلا فالمرأة يمكن أن تتمنى الموت لذئى لذلك أيضًا نسأل اله العافية'.

وكالحديث السابق في استعمال تركيب "لا نقوم الساعة حتى..." حيث ذكر هنا شيئا آخر، وهو موجود بشكل نسبي في هذا الزمن، رأيته من

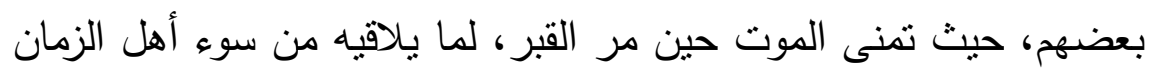

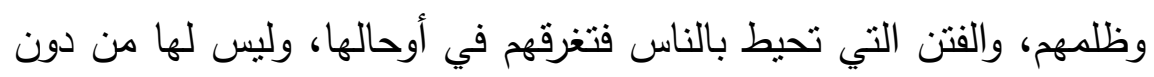
الاعتصام باله كاشفة. نسأل اله السلامة والعافية.

وقد صور النبي الكريم الحالة النفسية الرهيبة التي يعانيها هؤلاء الناس بين بدي الساعة، إذ تمنى الموت أمر صعب على النفس، وقد جبلت

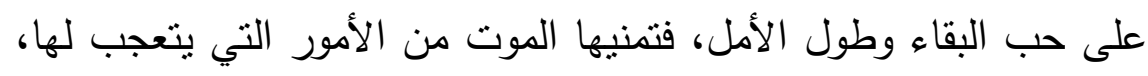
ولكن الأعجب ما تراه من فتن كقطع الليل المظلم، يجعل تمني الموت أمرا

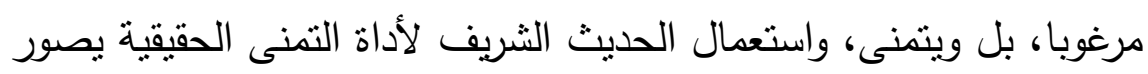
حقيقة نفسية المتمنيّ للموت، فهو بتمني الموت يرجو الخلاص مما هو فيه،

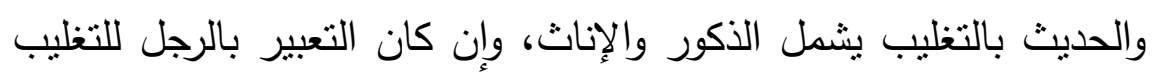

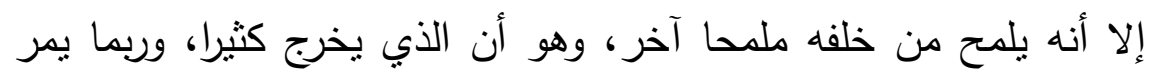

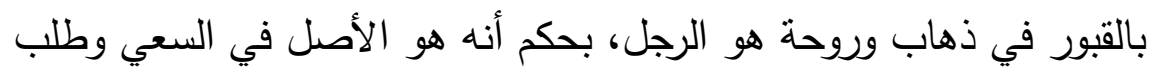

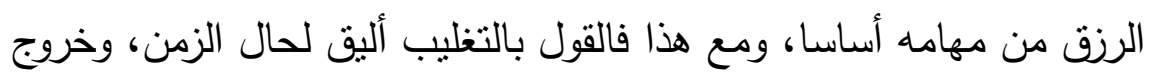
المرأة لكل شيء من رزق وغيره، حتى إن المكث في البيت الآن أصبح

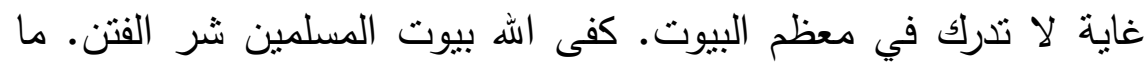
ظهر منها وما بطن.

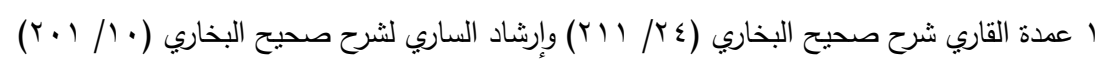


صن بلاغة النبي العدنان في دديثه عن فتن آذر الزهان فيها اتفق عليه الشيذان.

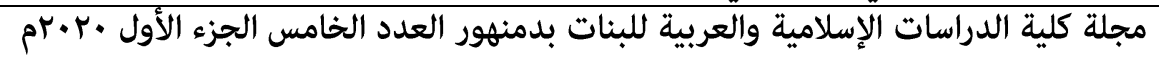

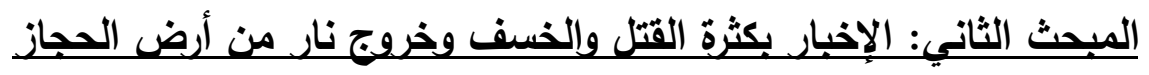

أولا: كثرة القتل

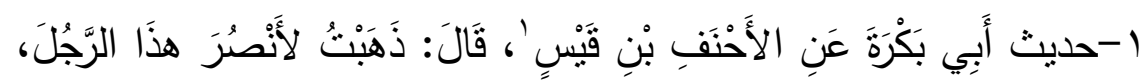

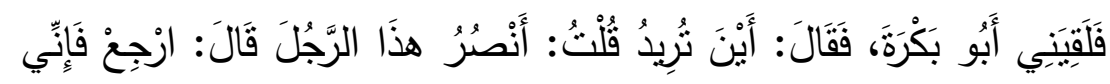

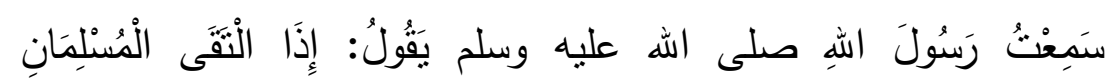

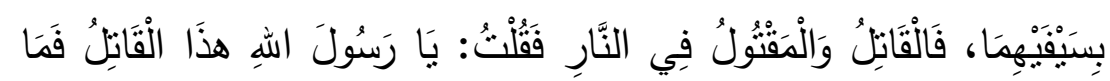

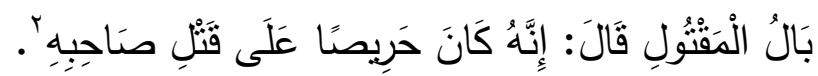

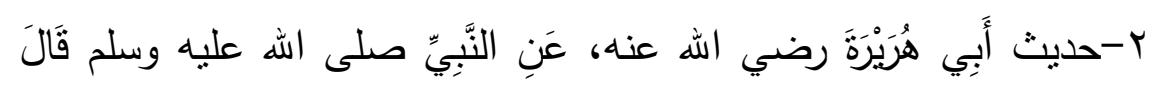

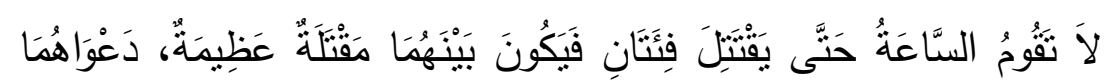
وَاحِدِّه.

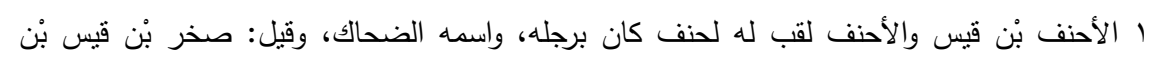

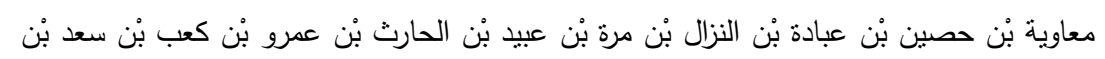

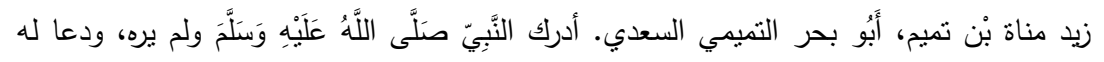

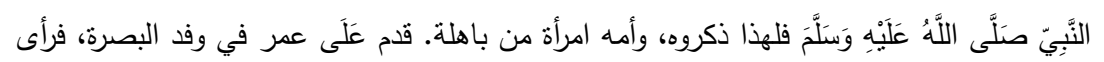

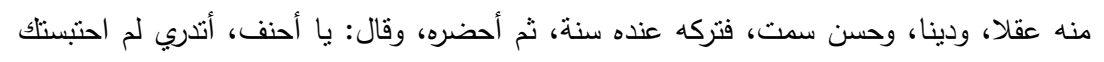

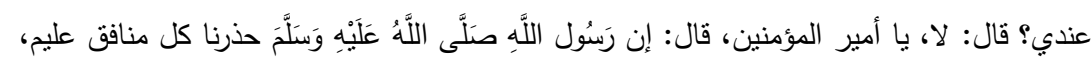

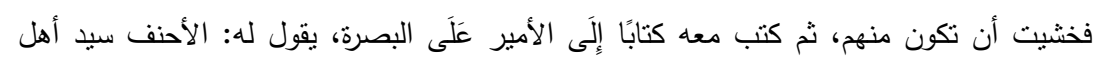

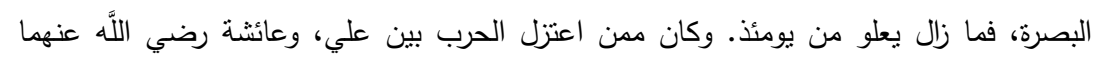

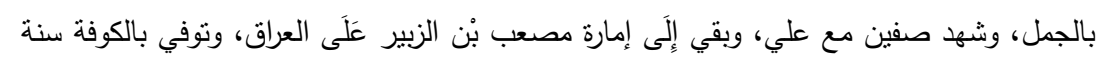

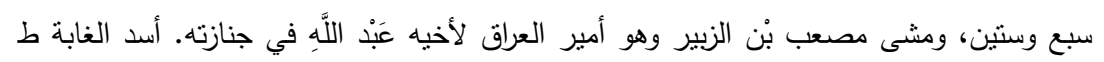

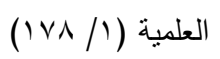

r أخرجه البخاري في: r r كتاب الإيمان: r r باب المعاصي من أمر الجاهلية وصحيح مسلم-

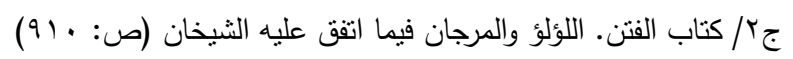

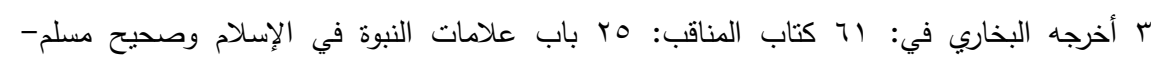

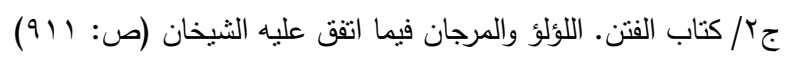


من بلاغة النبي العدنان في دليثه عن فتن آذر الزهان فيها اتفق عليه الشيخان.

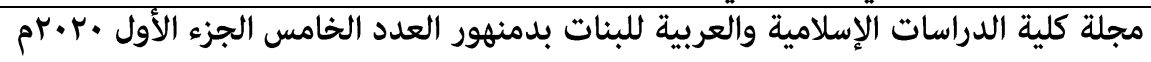

التحليل البلاغي والثرح: مجله الثانية

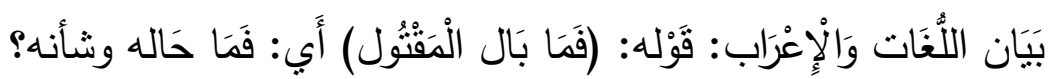

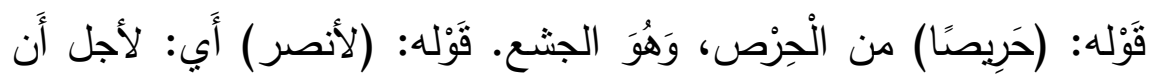

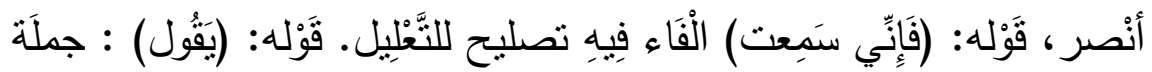
فِي مَحل النصب على الْحَال. قَوَله: (فالقاتل) الْفَاء جَوَاب: إِذا. قَوَّله: (هَذَا

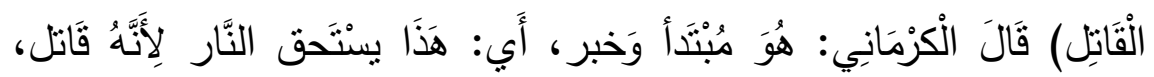

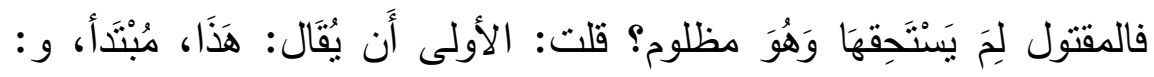

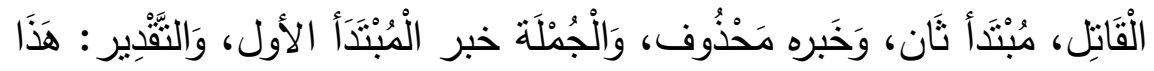

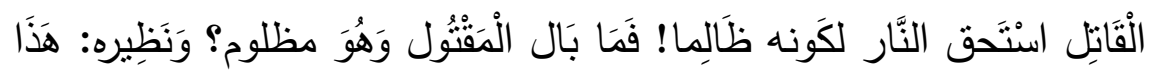

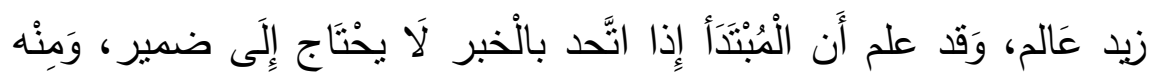

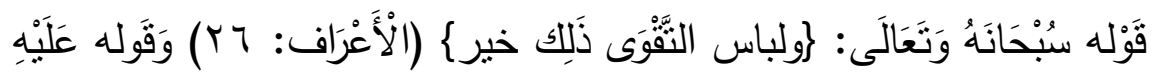

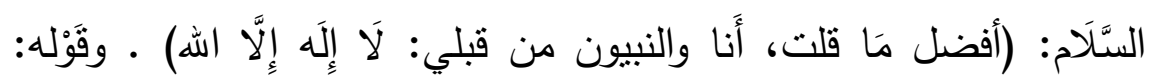
(انصر هَذَا الرجل) يَعْنِي: عَليّ بن أبي طَالب، رَضِي الله عَنهُ، وَقََّالَ

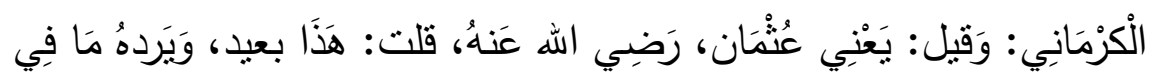

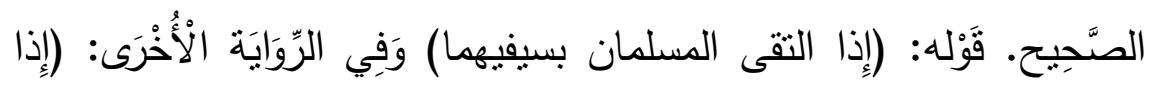

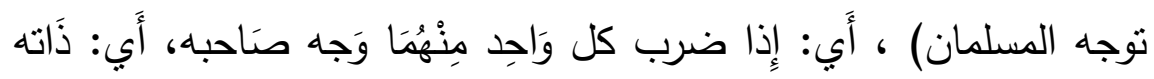

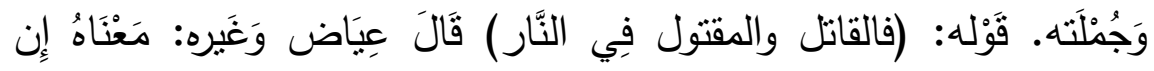

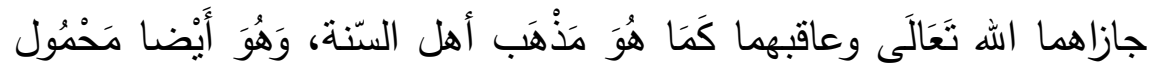

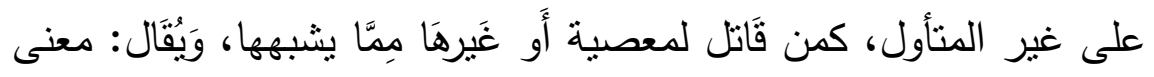

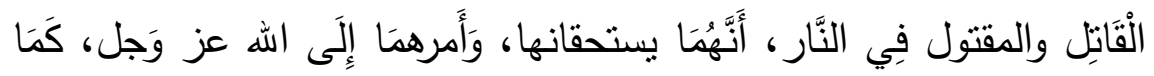

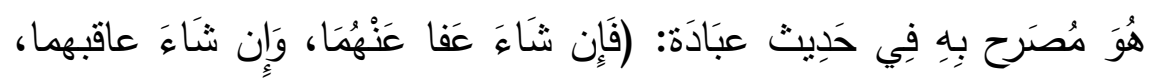

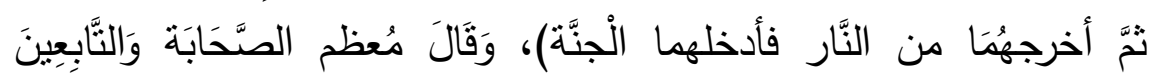

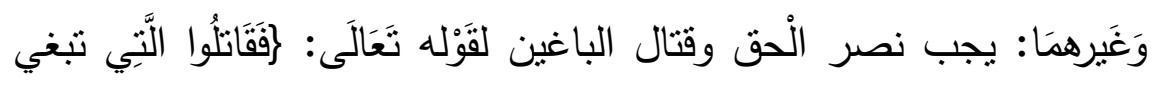


صن بلاغة النبي العدنان في دديثه عن فتن آذر الزهان فيها اتفق عليه الشيذان.

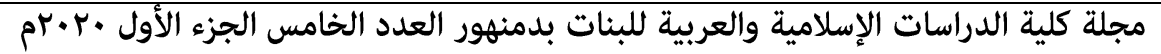

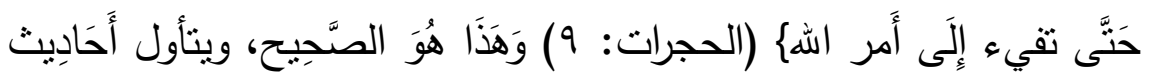

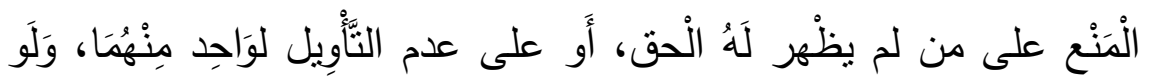

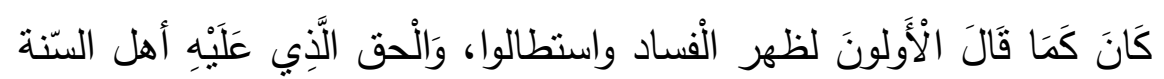

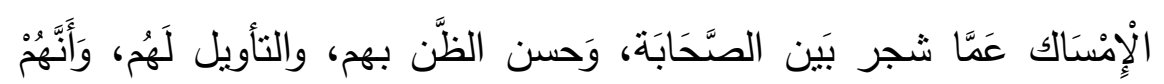

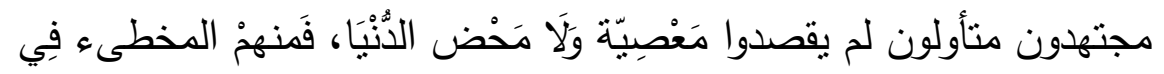

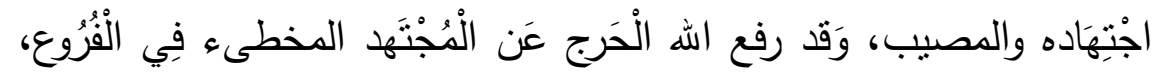

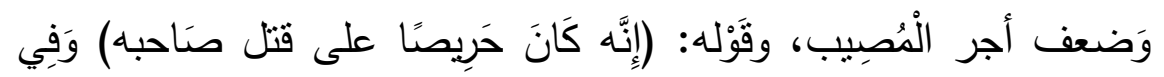

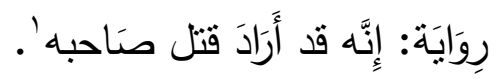

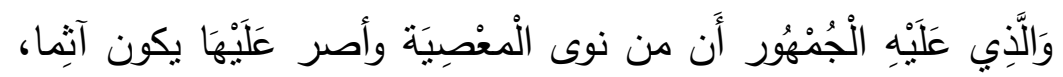

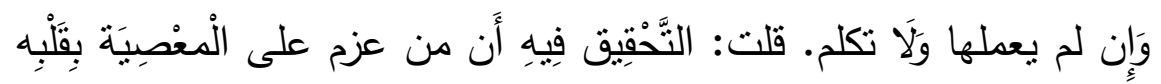

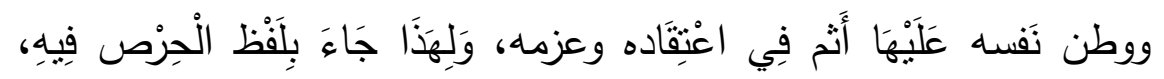

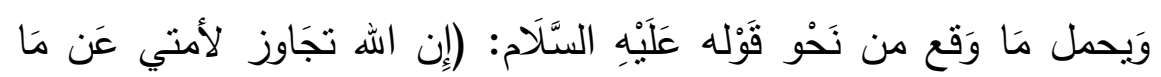

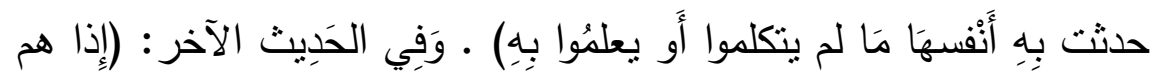

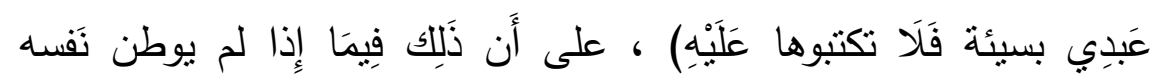

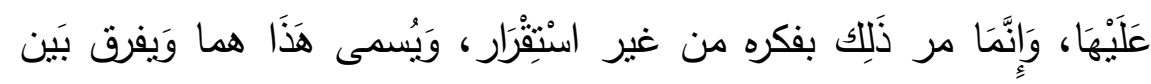

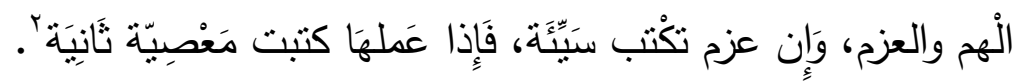

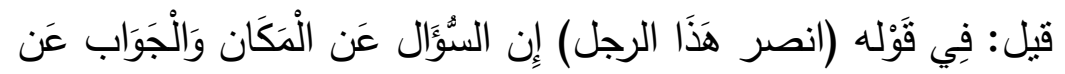

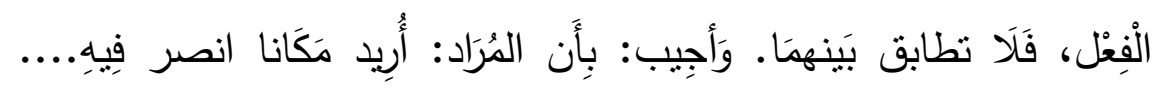

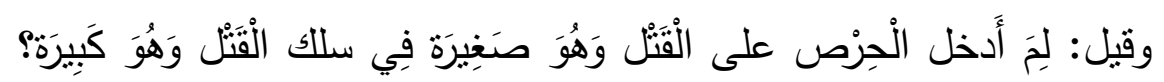

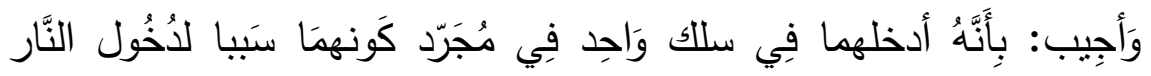

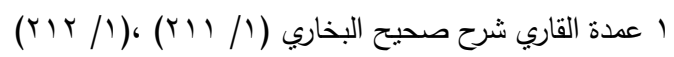

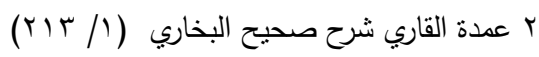


من بلاغة النبي العدنان في دلايثه عن فتن آذر الزمان فيها اتفق عليه الشيخان.

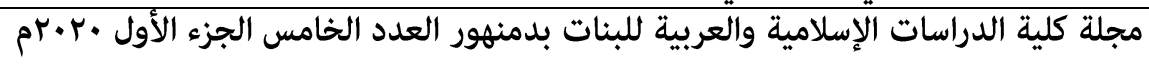

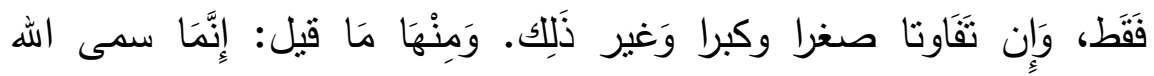

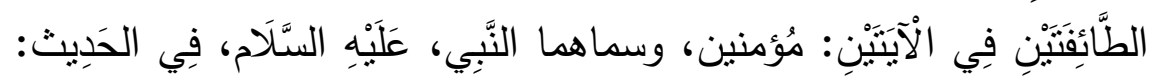

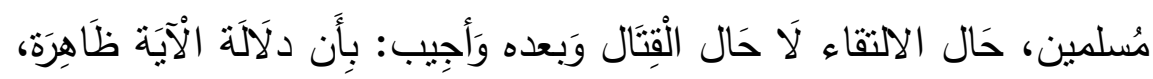

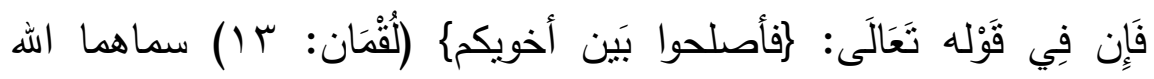

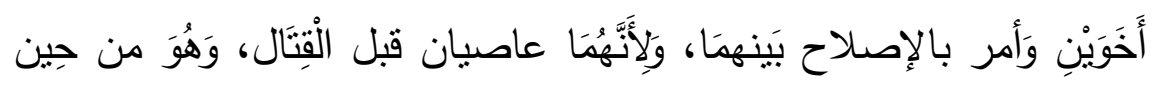

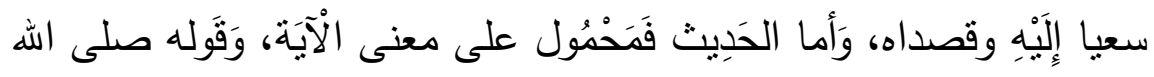
عَلَيْهِ وَسلم: (إذا التقى المسلمان بسيفهما فالقاتل والمقتول فِي النَّار ) ، المُرَاد

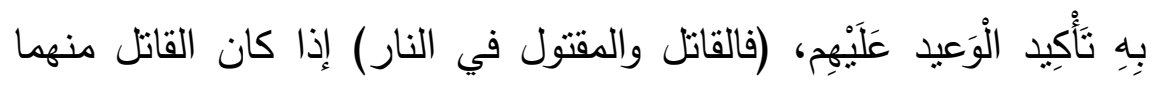

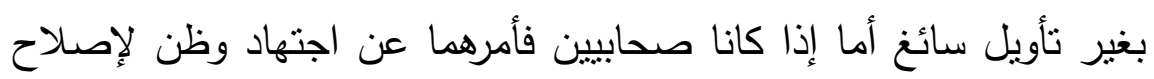

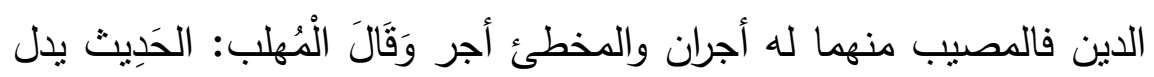

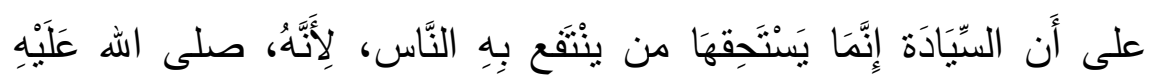

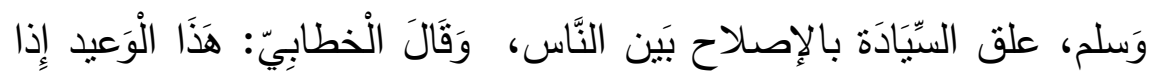

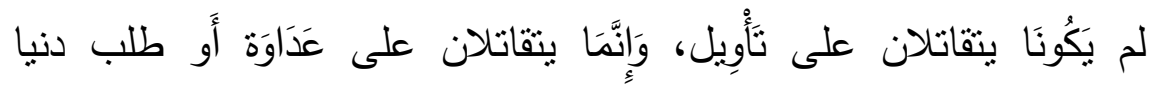

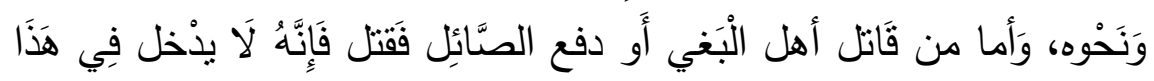

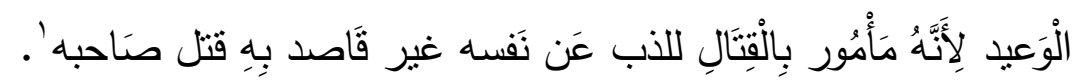
وإنما حمل أبو بكرة الحديث على عمومه في كل مسلمين التقيا

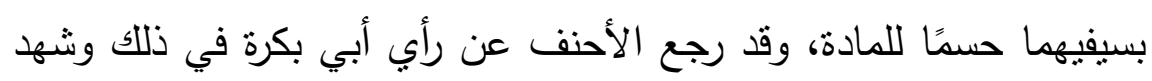
مع علي باقي حروبه، ، وقوله (إنه كان حريصًا على قتل صاحبه) مفهومه اله

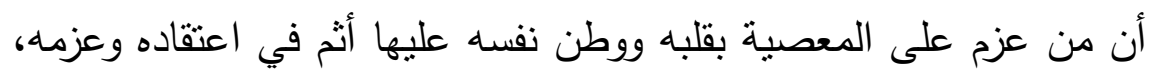
ولا تتافي بين هذا وبين قوله في الحديث الآخر "إذا همّ عبدي بسيئة فلم يعملها فلا تكتبوها عليه" لأن المراد أنه لم يوطن نفسه عليها وليه بل مرت بفكره

ا عمدة القاري شرح صحيح البخاري (r/ 


\section{صن بلاغة النبي العدنان في دديثه عن فتن آخر الزمان فيما اتفق عليه الشيخان.}

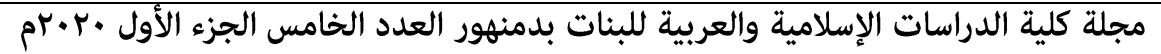

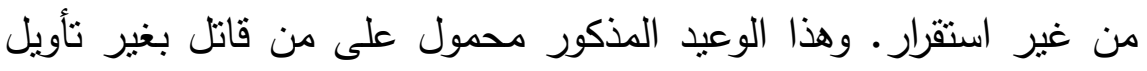

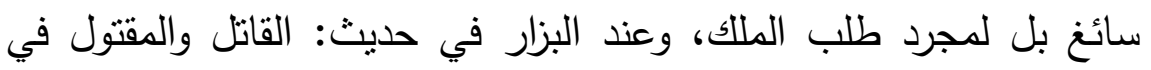
النار زيادة وهي إذا اقتتلتم على الدنيا فالقاتل والمقتول في النار '. أما الحديث الثاني:

حديث أَبِي هُرَيْرَة رضي الله عنه، عَنِ النَّبِِّ صلى الله عليه وسلم قَالَ

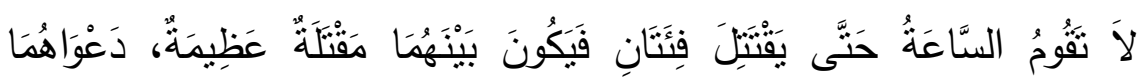
وَاحِدُّة

(لا تقوم الساعة حتى يقتنل فئتان فيكون بينهما مقتلة) بفتح الميم مصدر ميمي (عظيمة) أي قتل عظيم. وعند ابن أبي خيثمة في تاريخه أنه

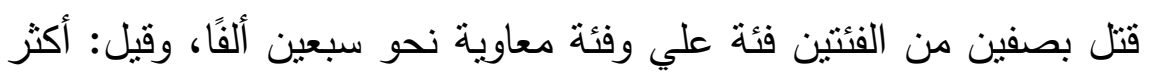

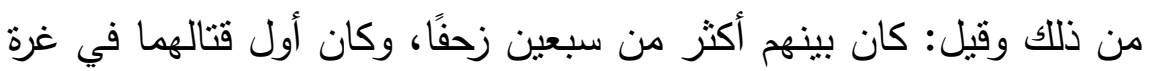

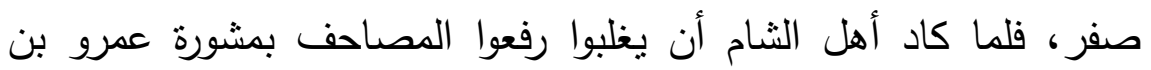
العاص ودعوا إلى ما فيها فآل الأمر إلى الحكمين فجرى ما جرى من إنى اختلافهما واستبداد معاوية بملك الثام واشتغال علي بالخوارج. (دعواهما واحدة) ويؤخذ منه الردّ على الخوارج ومن تبعهم في تكفيرهم كلاً من والن

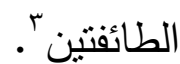

ولا يخفى علينا أن الغاية من إيراد هذه الأخبار بهذه الصورة وعلى

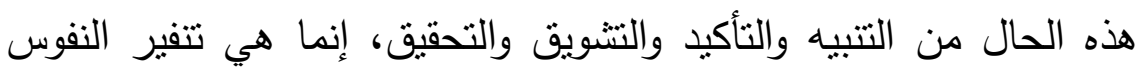

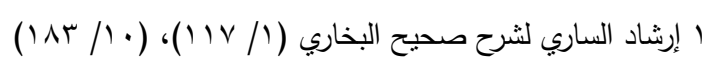

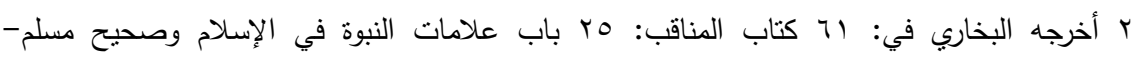

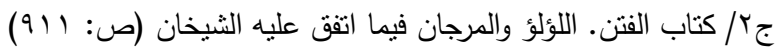

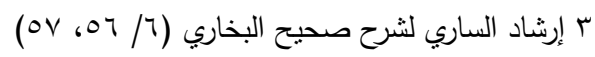


من بلاغة النبي العدنان في دايثه عن فتن آذر الزمان فيها اتفق عليه الشيخان.

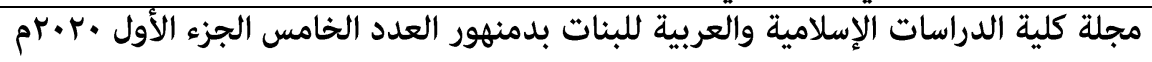

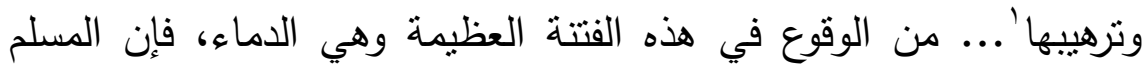
لا يزال في فسحة من دينه مالم يصب دما حراما، والحوار هنا في الحديث الأول وسيلة تربوية لإفهام المتلقي، كيف يتساوى جزاء القاتل والمقتول؟ والسؤال في الحديث على حقيقته، لأنه استقهام من لا يعلم، وإن كان يحمل جله معنى التعجب، لأن فطرة البشر وحكمة العقل ترفض أن يتساوى القاتل والمقتول في المآل، لكن التعليل جاء بأن الحرص على القتل مؤدٍ لهذه

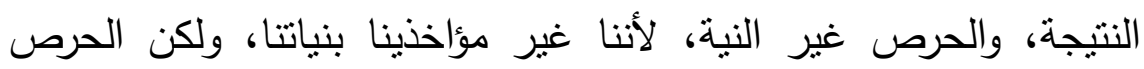
يجعل الإنسان يأخذ في الأسباب الداعية إلى تحقق الثيء الحئه الحريص على على

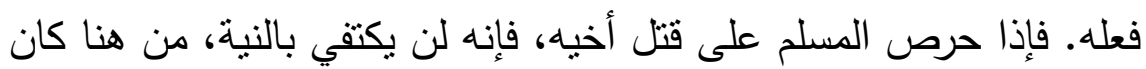
التهديد شديدا واللهجة والخبر صادما صارما، كلاهما في النار . وتصوير الحديث لهذا الجو النفسي بطريقة بلاغية وفي صورة موجزة من البلاغة بمكان، فالتعبير بإذا، التي تفيد تحقق وقوع الثرط بها غالبا، لأنه عند التلاقي بالسيوف لا مجال للرجعة، وتتصدر غريزة حب البقاء عند كل منهما، فهما بين قاتل ومقتول. وقد حرص الدين الإسلامي على حرمة الدم بين المسلمين خاصة وبين الناس عامة فجعل التهديد والوعيد في هذه المسألة يحمل من مؤثرات لإنين لغوية وبلاغية ما ينقل المشهد ويصوره، وينفر ويرهب من الوقوع فيه. ويأني الخبر الذي يتصدر دائما حديث قرب الساعة في الحديث الثاني (لا تقوم الساعة حتى .... فتجد الحديث استخدم : يقتنل مقتلة، والحديث قبله : القاتل والمقتول وقتل حيث وظفت تصاريف الكلمة في مكانها كل ذللك لسوق الترهيب والتتفير في نفس المتلقي، حتى يؤتي الحديث ثماره التعليمية، فإن البعد عن مواطن هذه الفتن نجاة بالدين. 
صن بلاغة النبي العدنان في دديثه عن فتن آذر الزهان فيها اتفق عليه الشيذان.

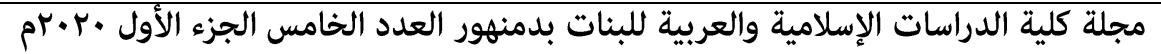

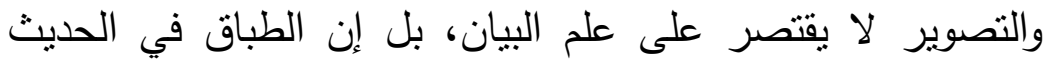
الأول ساعد على تصوير المعنى بشكل وضح الغرض من الحديث، فالقاتل والمقتول، المعتدي والمعتدى عليه في النار، تتفيرا لأي مسلم أن يكون في لهن منل هذه المواقف. أما الحديث الثاني فقد وقع بالفعل تلك المقتلة العظيمة التي راح فيها الكثير من المسلمين، في الفئتين اللتين تقاتلتا، فكان الإخبار بهما قبل

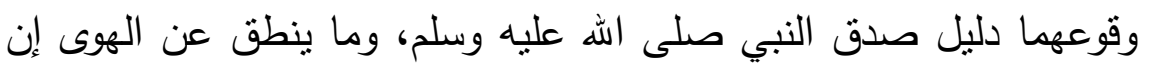
هو إلا وحي يوحى.

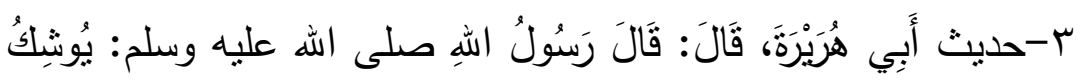

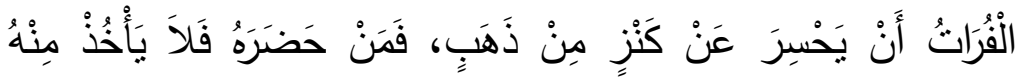

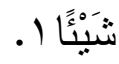

\section{ع -التحليل البلاغي والثرح:}

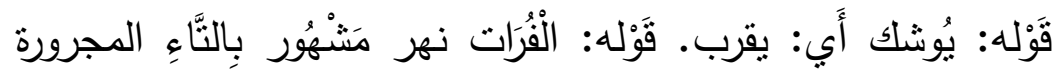

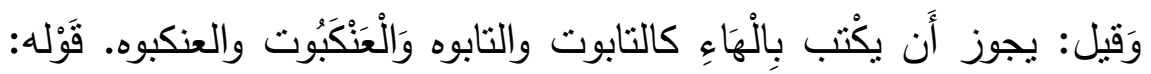

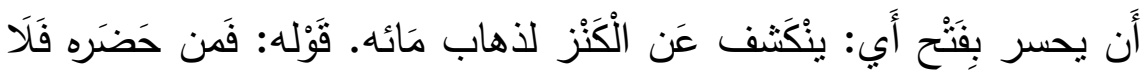

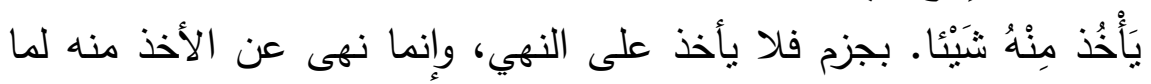

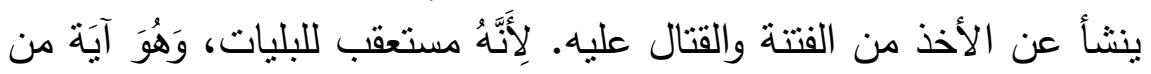

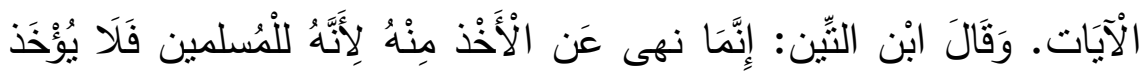

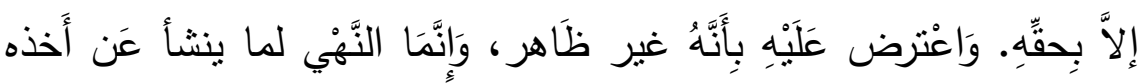

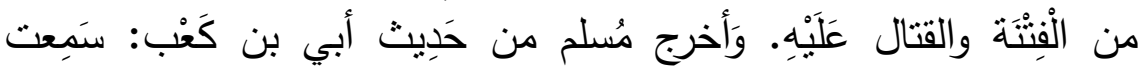

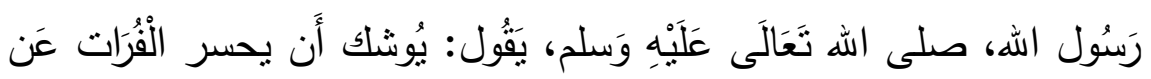

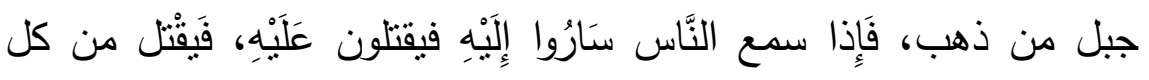

ا أخرجه البخاري في: بو كتاب الفتن: ع ب باب خروج النار وصحيح مسلم- جr/ كتاب الفتن. اللؤلؤ

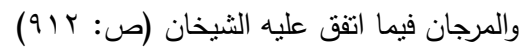




\section{صن بلاغة النبي العدنان في دايثه عن فتن آخر الزمان فيها اتفق عليه الشيخان.}

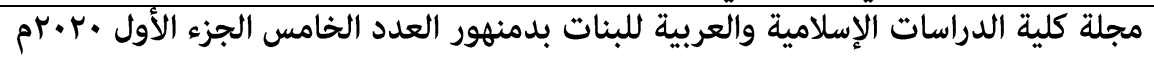

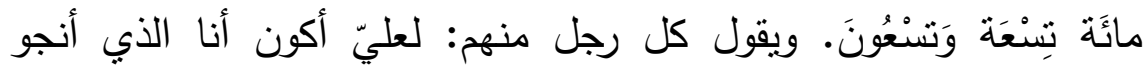

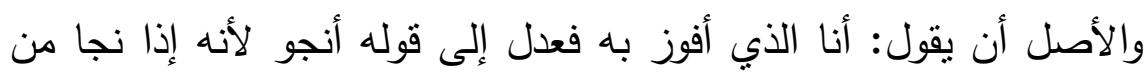

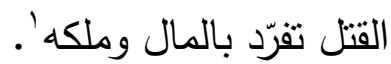

فهنا كذلك خبر من المستقبل، يخبر الصادق المصدوق الذي لا ينطق عن الهوى، خبر فيه تتبيه ونهي حقيقي عن الاختلاط بهذه الفتنة، وعلى قدر الرغبة في الكف على قدر قوة الأسلوب الذي يؤديه، قرب الزمن الذي ينكشف فيه كنز من ذهب بعد جفاف نهر الفرات، ومعلوم أن الإنسان يضعف أمام المال، فكان التهديد والنهي الثديد (فمن حضره فلا يأخذ منه دهن شيئا) فعبر بالمضارع لاستحضار الصورة وتصوير المستقبل، وعقد الثرط على الحضور، فمن حضره لا بأخذ منه شيء حتى لا يكون معرضا للقتل بسبب عرض من الدنيا.

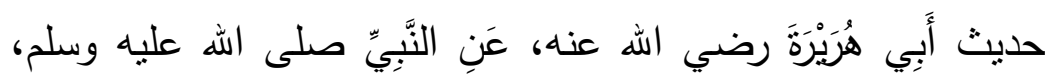

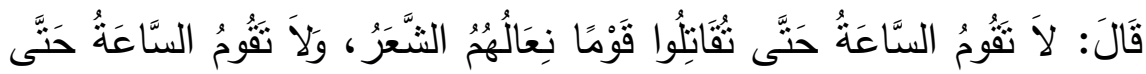

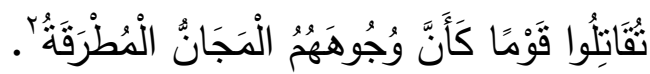

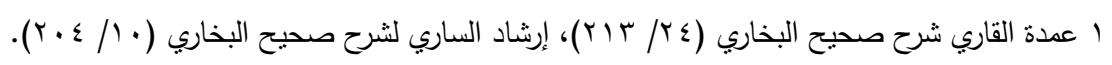

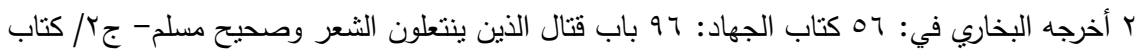

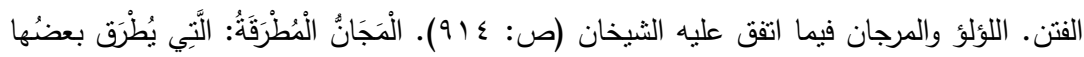

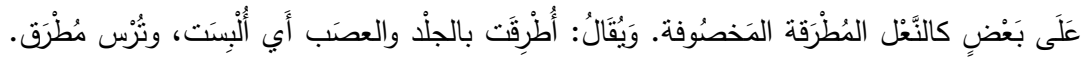

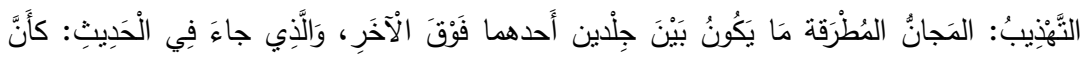

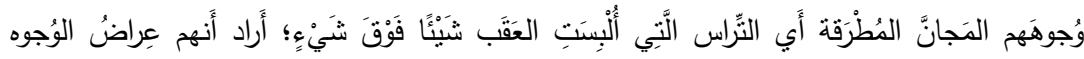

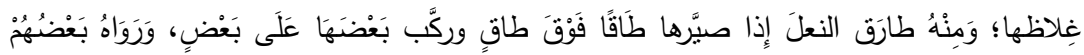

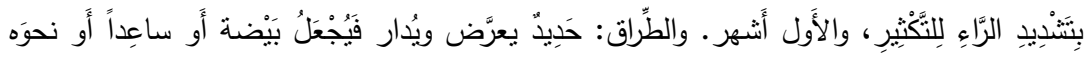

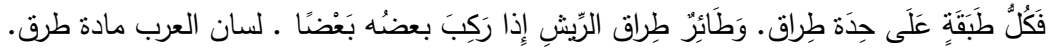




\section{صن بلاغة النبي العدنان في دديثه عن فتن آذر الزمان فيها اتفق عليه الشيخان.}

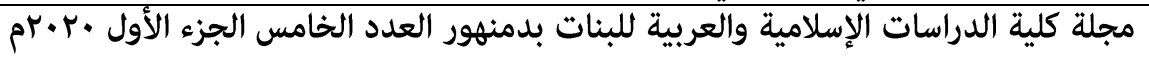

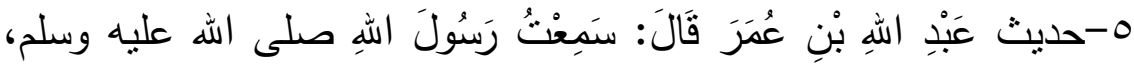

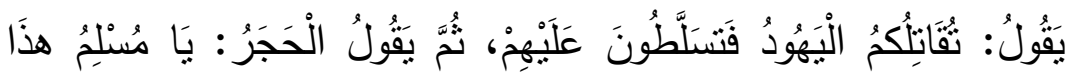

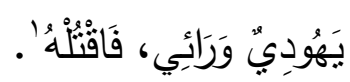

\section{التحليل البلاغي والثرح:}

(لا تقوم الساعة حتى تقانلوا قومًا) أي من الترك (نعالهم الثُعر) أي

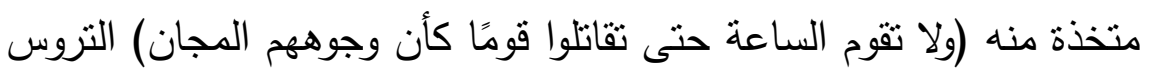
(المطرقة). التي بطرق بعضها على بعض كالنعل المطرقة المخصوفة إذا طرق بعضها فوق بعض ولأبي ذر المطرّقة بتشديد الراءَ.

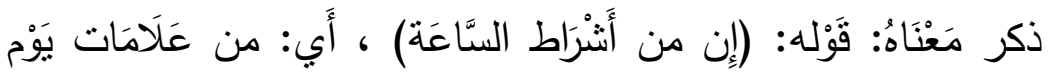

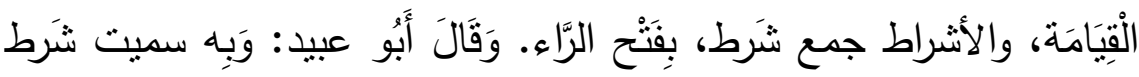

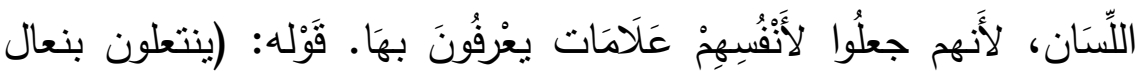

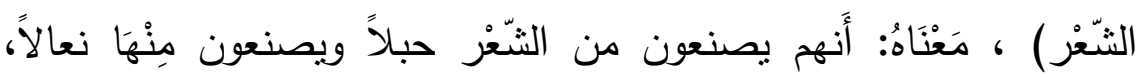

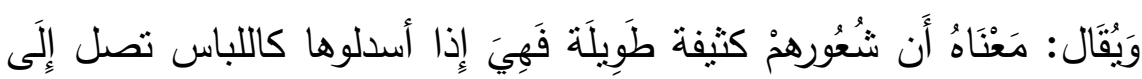

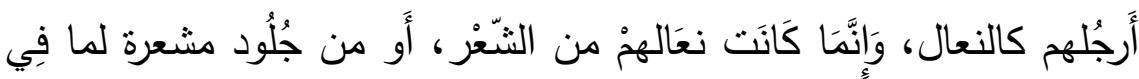

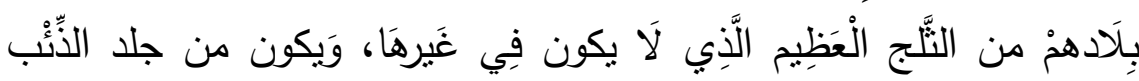

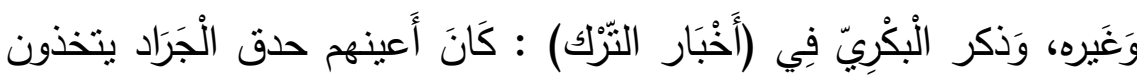

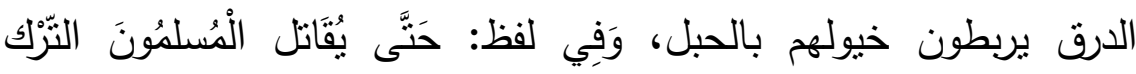

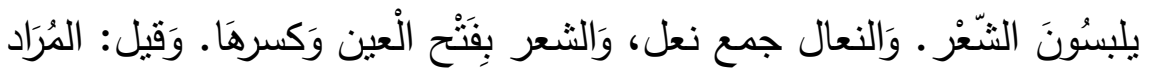

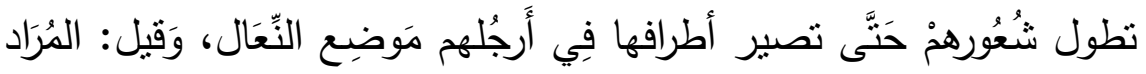

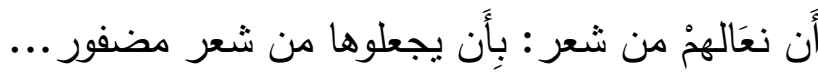

أخرجه البخاري في: آ كتاب المناقب:

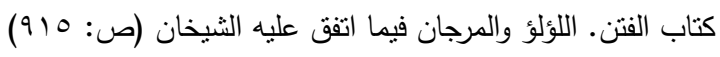
r إرشاد الساري لشرح صحيح البخاري (1/ ؟ ـ ـ (1). 
من بلاغة النبي العدنان في دلايثه عن فتن آذر الزمان فيها اتفق عليه الشيخان.

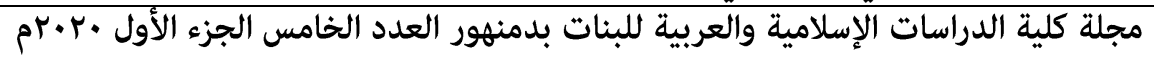

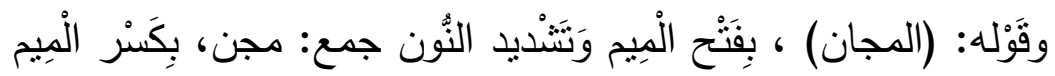

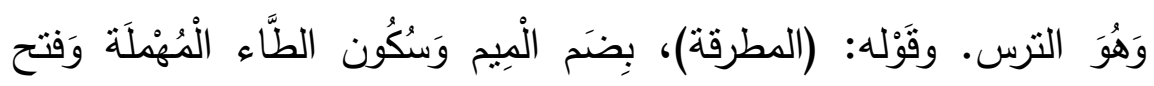

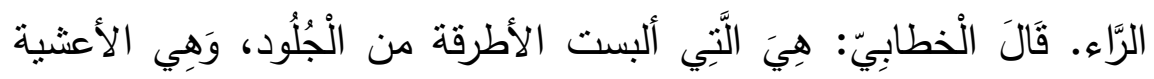

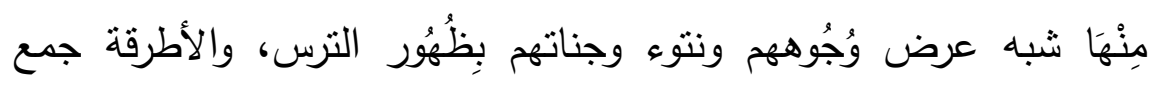

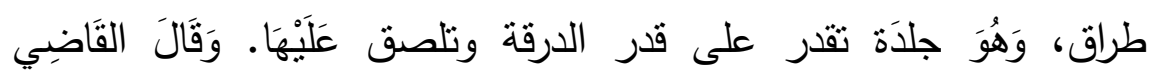

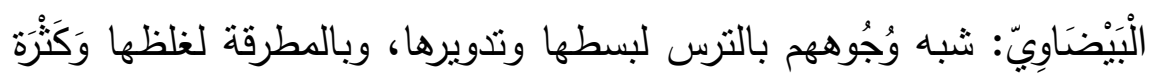

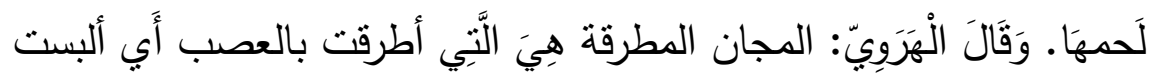

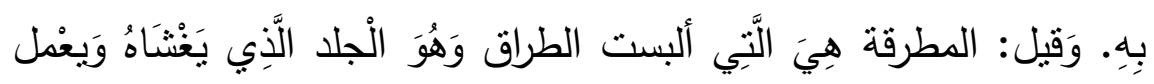

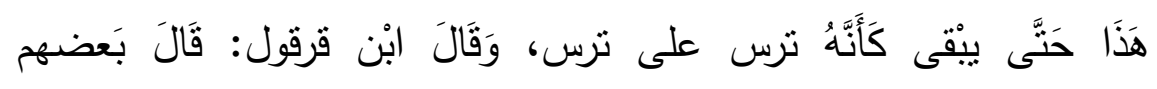

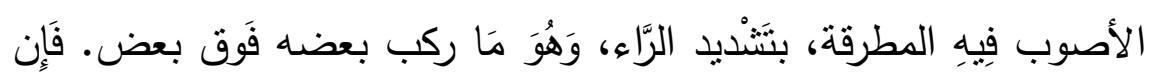

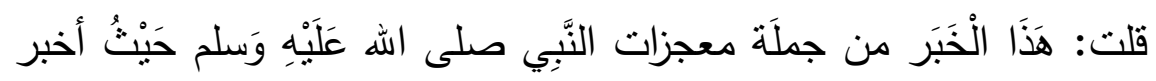

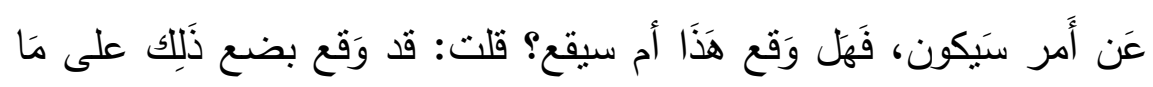

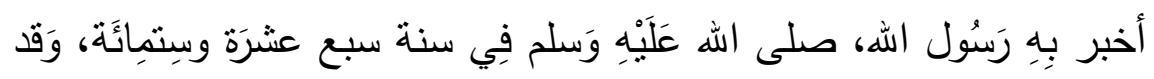

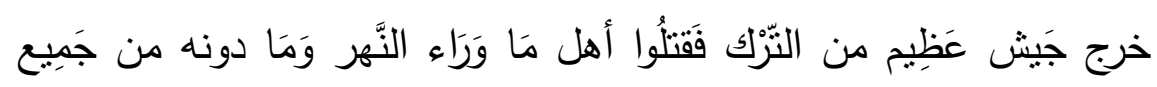

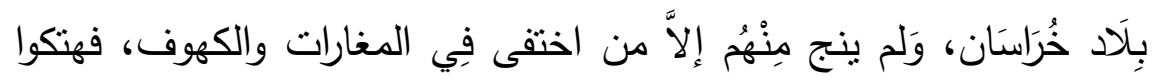

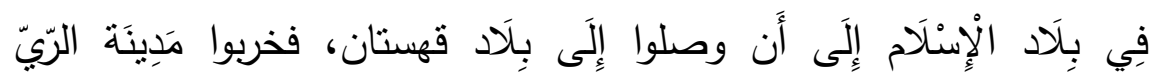

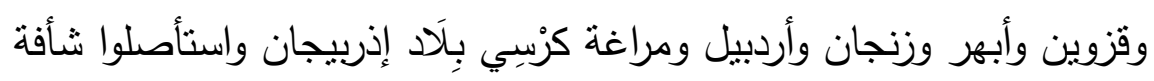

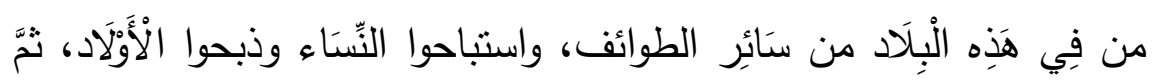

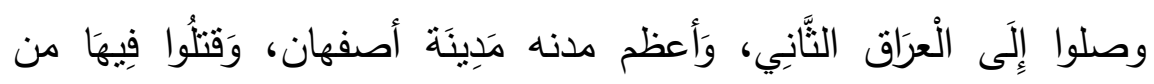

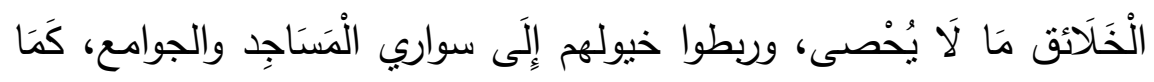

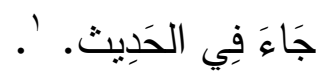

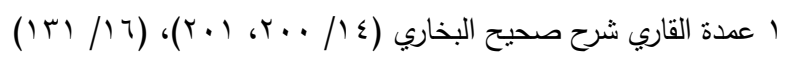


من بلاغة النبي العدنان في دديثه عن فتن آذر الزهان فيها اتفق عليه الشيذان.

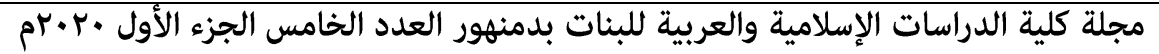

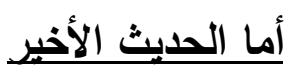

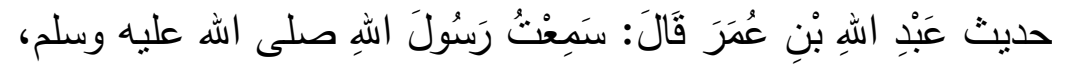

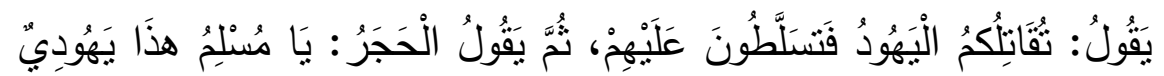

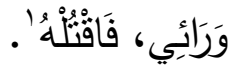

هذا إخبار من النبي -صَتَّى اللَّهُ عَلَيْهِ وَستَلَّمَ- عن (قتال اليهود) الكائن في مستقبل الزمان.

(عن عبد الله بن عمر -رضي الله عنهما- أن رسول الهه --صَّلَّى اللَّهُ عَلَيْهِ وَسَلَّمَ- قال): مخاطبًا للحاضرين والمراد غيرهم من أمته. (تقاتلون اليهود) لأن هذا إنما يكون إذا نزل عيسى عليه السلام فإن المسلمين يكونون معه واليهود مع الاجال (حتى يختبئ) أي يختفي (أحدهم وراء الحجر فيقول): أي الحجر حقيقة (يا عبد الله هذا يهودي ورائي فاقتله). وفي رواية (لا تقوم الساعة حتى تقاتلوا اليهود) الذين يكونون مع الدجال عند نزول عيسى عليه السلام (حتى يقول الحجر وراءه اليهودي يا مسلم: هذا يهودي ورائي فاقتله). فقيه ظهور الآيات قرب الساعة من كلام الجماد، ويحتمل المجاز بأن يكون المراد أنهم لا يفيدهم الاختباء والأول أولى. و فيه هيه إثارة إلى بقاء دين المسلمين إلى أن ينزل عيسى عليه السلام فإنه الذي لي لهرد

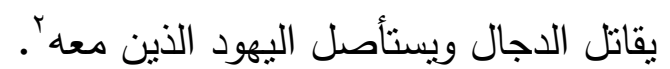
ويتضح من الحديث تعانق كل من الخبر والإنشاء في تصوير المعنى، حيث بدأ الحديث بالفعل المضارع الذي يدل على استحضار الصورة، وفي نفس الوقت إخبار بما سيقع في مستقبل الزمان قرب قيام

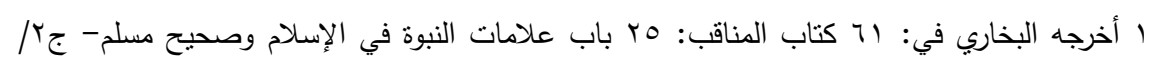

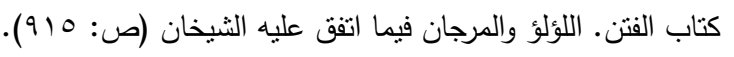

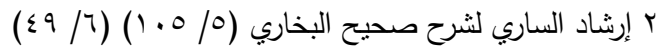




\section{صن بلاغة النبي العدنان في دايثه عن فتن آخر الزمان فيها اتفق عليه الشيخان.}

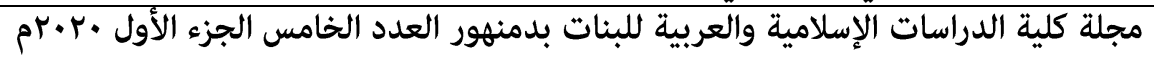

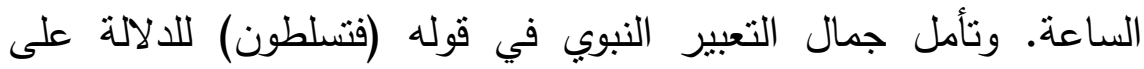
الغلبة، والقوة والاستحكام الذي يكون فيه المسلمون يومئذ. ثم يصور النبي الكريم إحدى المعجزات التي تكون في أخر الزمان، ممازجا بين الخبر والإنشاء: (فيقول الحجر: يا مسلم هذا يهوديي ورائي فاقتله) خبر فنداء فخبر فأمر، وبالإنشاء يقوى الخبر ، وبهما تكتمل الصورة المعبرة المؤثرة.

\section{ثنانيا: الخسف}

حديث عَائشَنَةَ، قَالَتْ: قَالَ رَسُولُ اللهِ صلى الله عليه وسلم: يَغْزُو

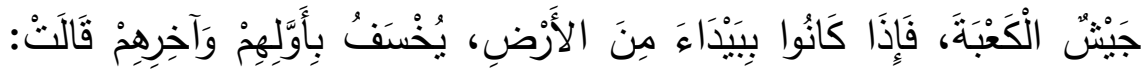

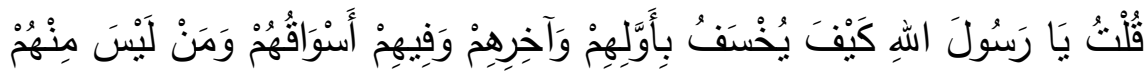

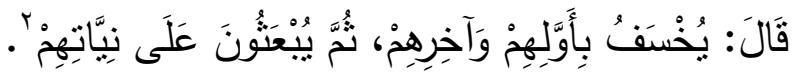

\section{التحليل البلاغي والثرح:}

قال رسول الله -صَلَّى اللَّهُ عَلَيَهِهِ وَسَلَّمَ-: يغزو) أي يقصد (جيثس الكعبة) لتخريبها (فإذا كانوا بيبداء من الأرض) هي بيداء المدينة (يخسف بأوّلهم وآخرهم) وزاد الترمذي في حديث صفية ولم ينج أوسطهم ولمسلم في حديث حفصة فلا يبقى إلا الثريد الذي يخبر عنهم. قلت: يَا رَسُول الله

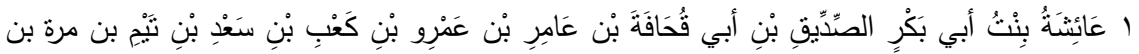

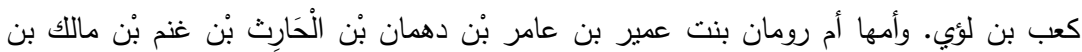

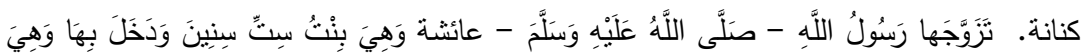

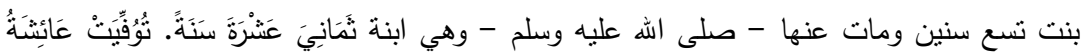

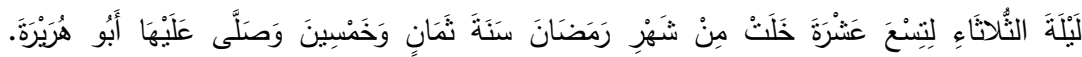

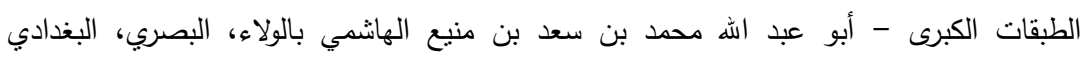

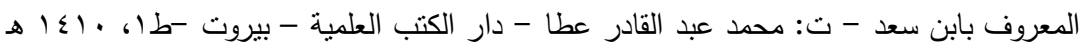

$$
\text { ( } 199 / \Lambda) \text {. } 199
$$

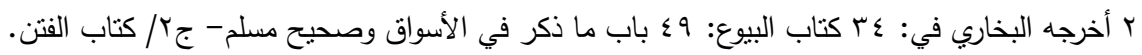
اللؤلؤ والمرجان فيما اتفق عليه الثيخان (ص: 9 ـ 9 ( 9 
صن بلاغة النبي العدنان في دديثه عن فتن آذر الزهان فيها اتفق عليه الشيذان.

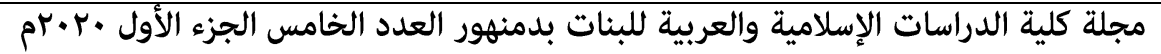

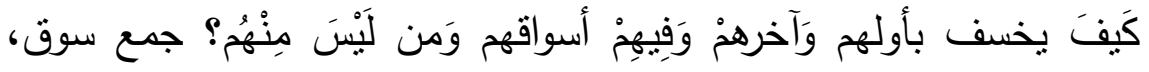
والتقدير أهل أسواقهم الذين يبيعون ويشترون كما في المدن قَّلَ: (يخسف بأوّلهم وآخرهم) لشؤم الأشرار (ثم يبعثون على نياتهم) فيعامل كل أحد عند الحساب بحسب قصده. وفيه التحذير من مصاحبة أهل الظلم ومجالستهم

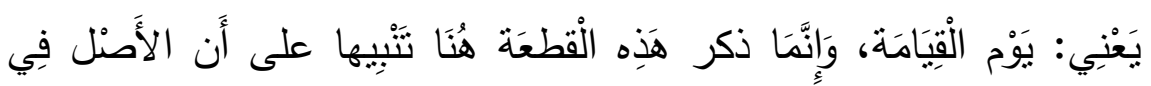

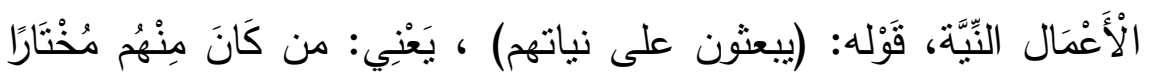

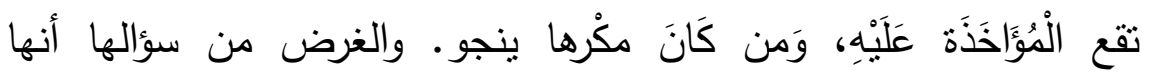

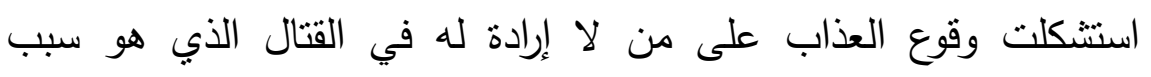

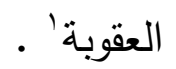

ويتصدر البيان النبوي هنا الفعل المضارع، لأنه هو المناسب للمقام

المخبر عما سيكون في مستقبل الزمان الآخر • والحوار الذي في الحديث بين أم المؤمنين ورسول الله ييرز تأثنير الحديث النبوي في بناء عقول

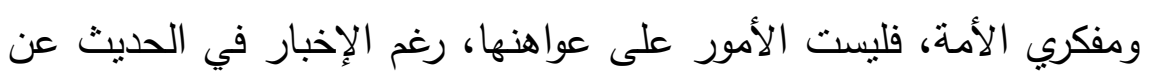

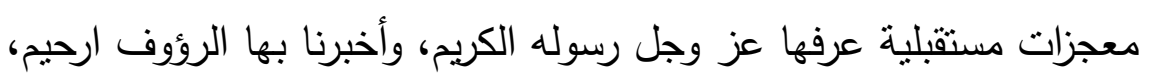
ليتخذ كل لنفسه وقاء ويتعوذ من الفتن ما ظهر منها وما بطن.

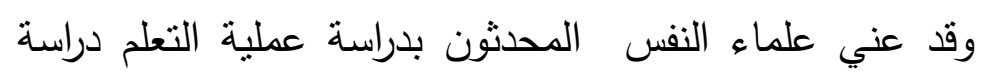
مستفيضة، وتوصلوا إلى تحديد دقيق لمبادئ التعلم التي تجعل من التعلم عملية سهلة ميسرة،ولقد طبق الرسول صلى الله عليه وسلم مبادئ التعلم في التربية النفسية لأصحابه، وبناء شخصياتهم وفي نشر الدعوة الإسلامية بين

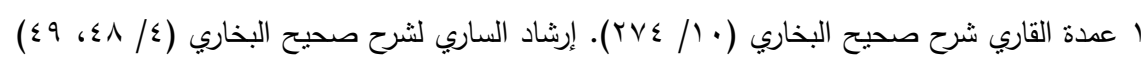
بتصرف 
من بلاغة النبي العدنان في دايثه عن فتن آذر الزهان فيها اتفق عليه الشيذان.

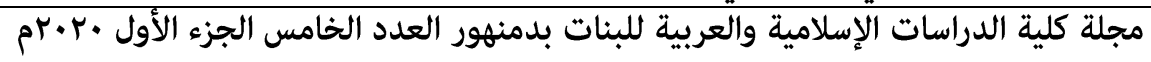
الناس.... وكان من أهم هذه المبادئ خلق الدافع في التعلم، ويمكن إثارة

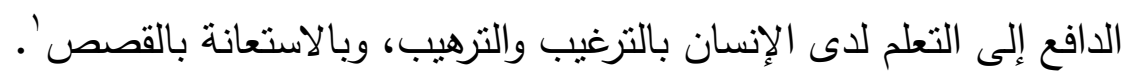
والجملة الشرطية في الحديث رتبت الجزاء على العمل، فإن جزاء من يحاول غزو بيت الله والقتال فيه مستحق للخسف، ولو أخذ في الطريق من كان مكرها، أو ليس ممن يغزو • وهذا دليل على الفتتة الماحقة التي ستكون، وتحذير شديد بتصويرها بهذه الصورة المفزعة، حتى لا يكون هناك عذر لهر لهري لمن حضرها.

ويتآزر الخبر مع الإنشاء في الحديث الثربف ليصور الموقف رأي

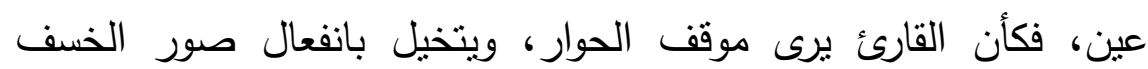

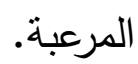

ثالثا: خروج النار من أرض الحجاز

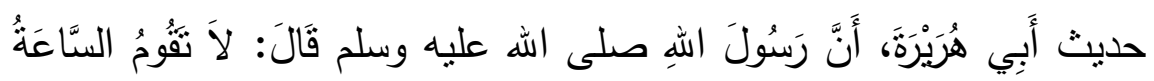

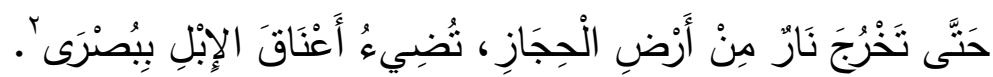
التحليل البلاغي والثرح:

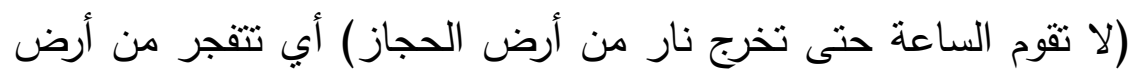

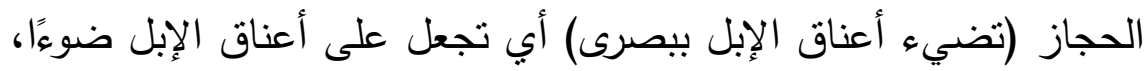

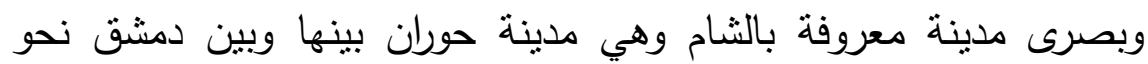

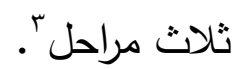

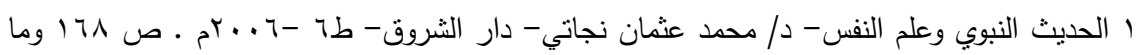
بعدها. باختصار r أخرجه البخاري في: ra كتاب الفتن: ع ب باب خروج النار وصحيح مسلم- جr/ كتاب الفتن. اللؤلؤ

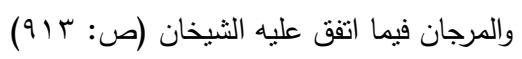

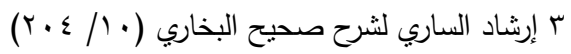


صن بلاغة النبي العدنان في دديثه عن فتن آذر الزهان فيها اتفق عليه الشيذان.

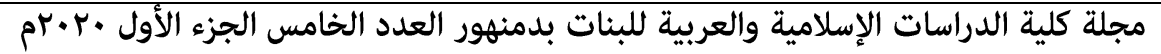

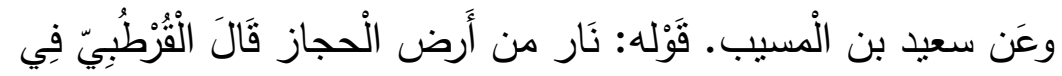

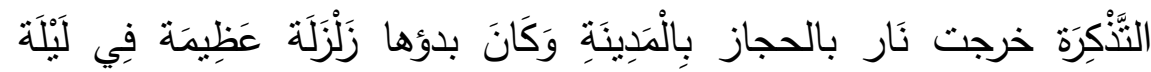

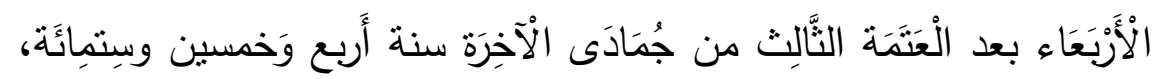

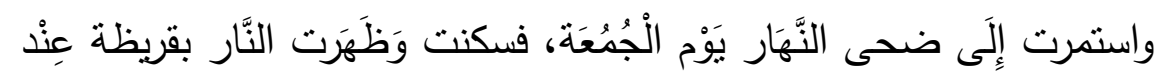

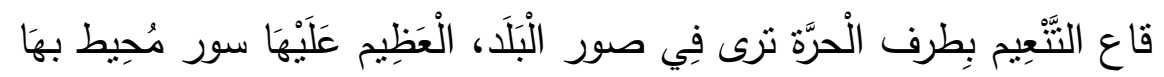

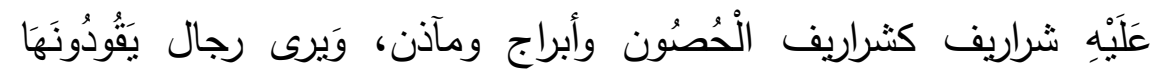

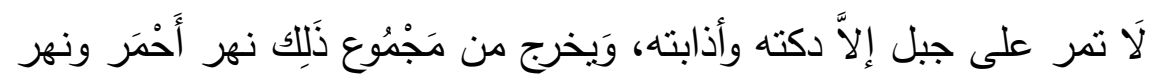

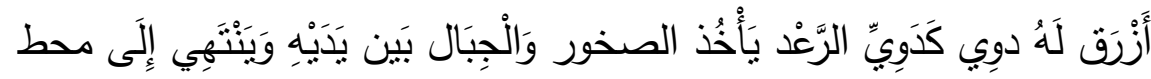

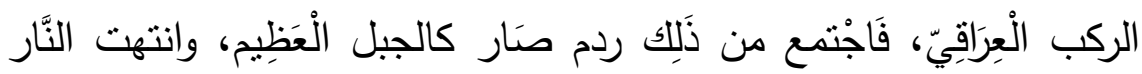

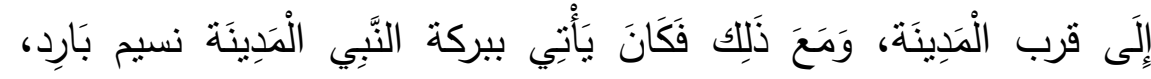

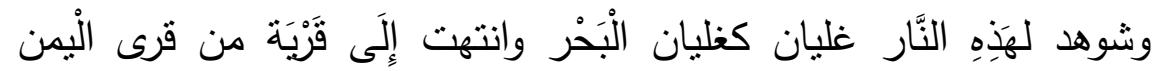

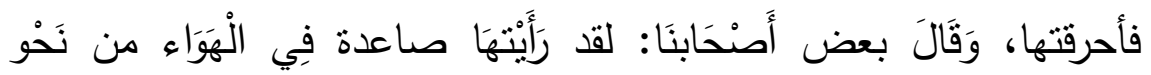

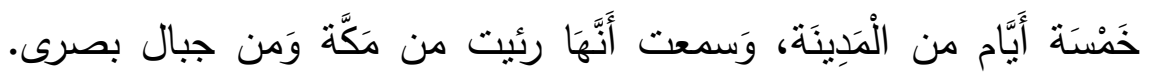

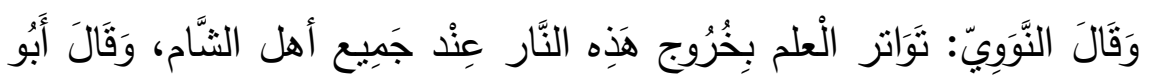

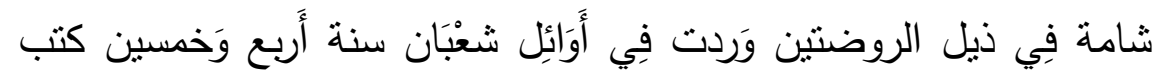

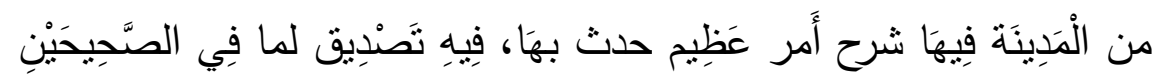

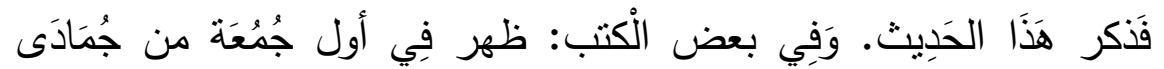

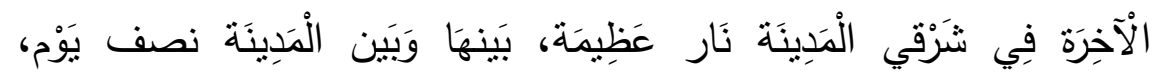
انفجرت من الأَزْض وسال مِنْهَا وَاد من نَار حَتَّى حَاذَى جبل أحد، وَفِي

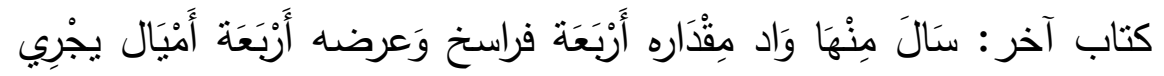

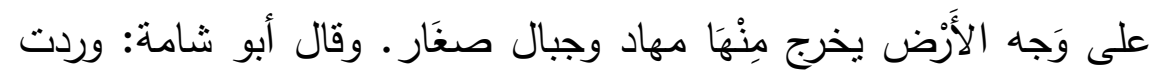

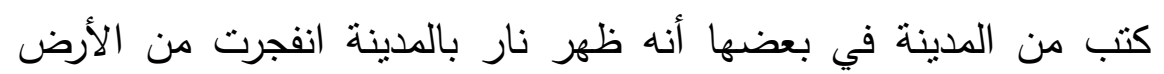

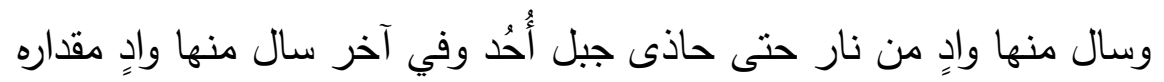


صن بلاغة النبي العدنان في دليثه عن فتن آذر الزهان فيطا اتفق عليه الشيخان.

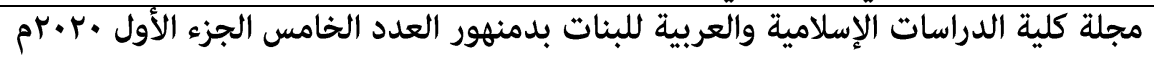

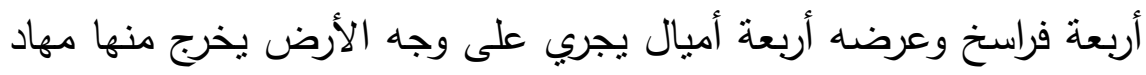
وجبال صغار ، وقال في جمل الإيجاز : وحكى لي جمع ممن حضر : إن النفوس سكرت من حلول الرجل، وفنيت من ارتقاب نزول الأجل، وعجّ ونج المجاورون في الجؤار بالاستغفار، وعزموا على الإقلاع عن الإصرار

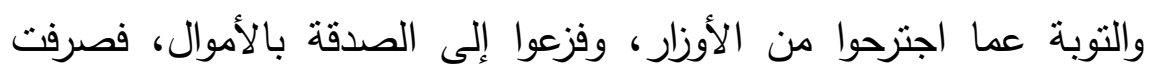
عنهم النار ذات اليمين وذات الثمال وظهر حسن بركة نبينا -صنَّلَّى اللَّهُ

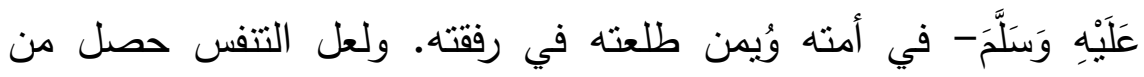

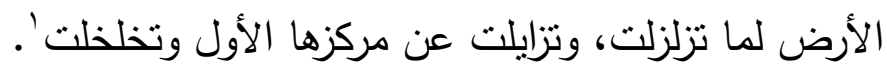
وأما إضاءة أعناق الإبل بيصرى فقد جاء من أخبر به، فإذا ثبت هذات

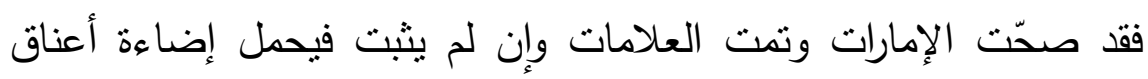
الإبل ببصرى على وجه المبالغة، وذللك في لغة العرب سائغ. وفي باب التنبيه في البلاغة بالغ وللعرب في التصرف في المجاز ما يقتضي للغتها بالسبق في الإعجاز ، وعلى هذا يكون القصد بذلك التعظيم لشأنها والتفخيم لمكانها والتحذير من فورانها وغليانها، وقد وجد ذلك على وفق ما أخبر وقد جاء من أخبر أنه أبصرها من تيماء وبصرى على مثل ما هي من المدينة

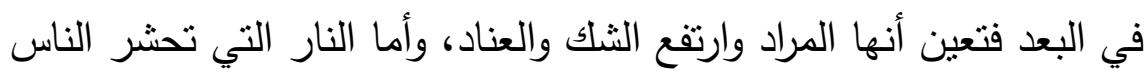

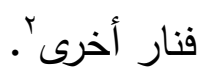

ومع علامة جديدة من علامات اقتراب الساعة، وفتتة من فتن أخر الزمان، ومن نص الحديث وشروحه، يتضح أنها علامة متكررة، حدثت وستحدث، وهو ما يجعل كلام المصطفى مطابقا للحال في كل زمان

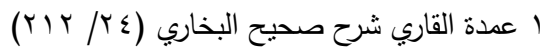

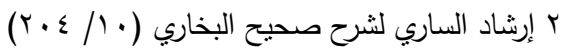




\section{من بلاغة النبي العدنان في دديثه عن فتن آذر الزمان فيها اتفق عليه الشيخان.}

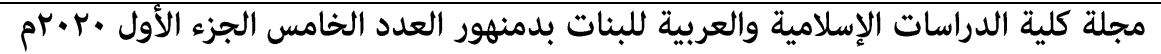

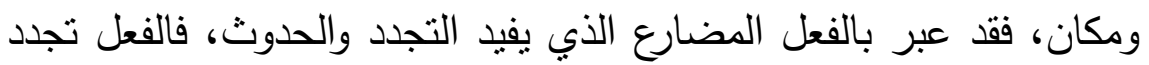
حدوثه، وسيتجدد وقوعه حتى تقوم الساعة.

صور المصطفى صلى الله عليه وسلم بالكلمات هذه الصورة المرعبة،

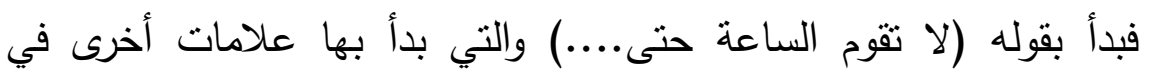
أحاديث أخر، تتبيها ولفتا للذهن، لكي يتلقى القادم بعدها بشغف واهتمام، فإن الأمر جد خطير، ولابد لكل مسلم أن يعد العدة ليقابل تلك الفتن المتتابعة تترى كقطع الليل المظلم، نسأل الله السلامة في ديننا. وللمبالغة في التصوير وبعيدا عن القول بالاستعارة في قوله (تضيء أعناق الإبل في بصرى) حيث أخبر بعض شراح الحديث أنه بيكن أن

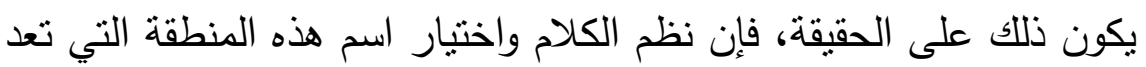

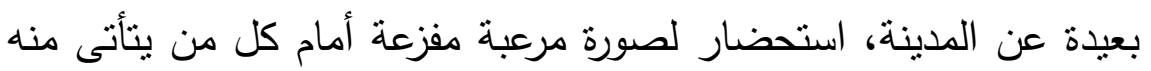

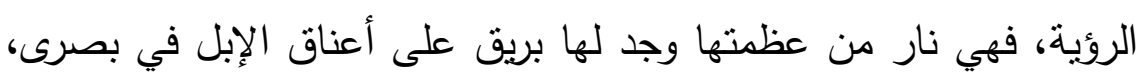
وهي مدينة في الثام، وأين الثام من مدينة رسول الله صلى الله عليه وسلم.

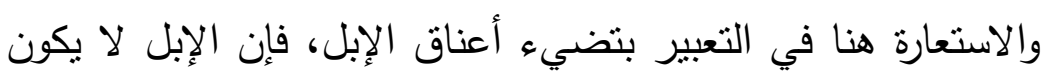

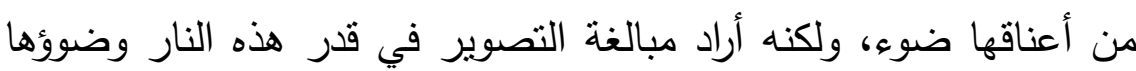
الذي يخيل للرائي أنه جعل أعناق الإبل تضيء اعنه من شدة لمعانها، من انعكاس لهب النار عليها. 
هن بلاغة النبي العدنان في دديثه عن فتن آذر الزهان فيها اتفق عليه الشيخان.

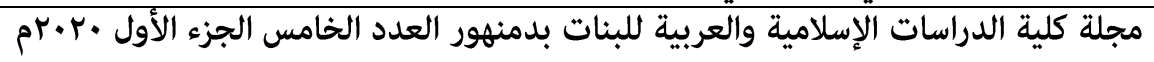

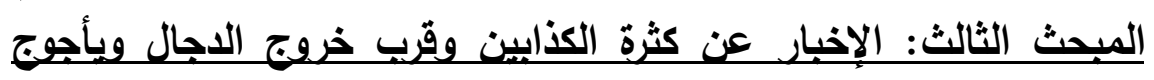

ومأجوج

أولا: كثرة الكذابين وظهور الدجال

ا-حديثث أَبِي هُرَبْرَةَ رضي الله عنه، عَنِ النَّبِِِ صلى الله عليه وسلم قَالَ:

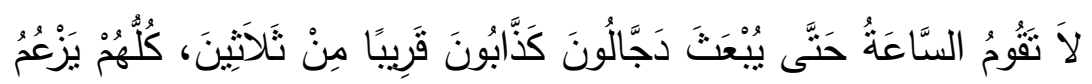

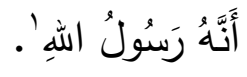

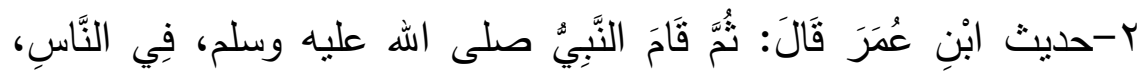

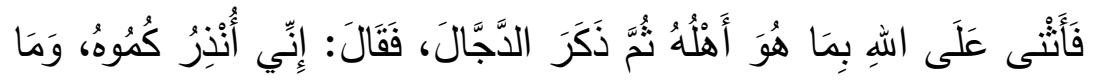

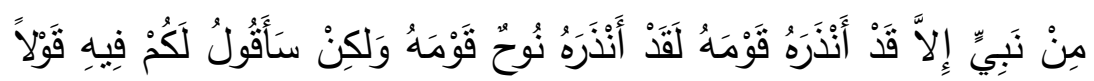

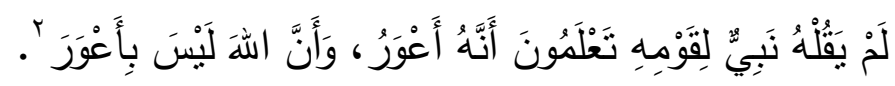
س-حديث عَبْد اللهِ بْنِ عُمَرَ قَالَ: ذَكَرَ النَّبيُّ صلى الله عليه وسلم يَوْمًا، بَيْنَ

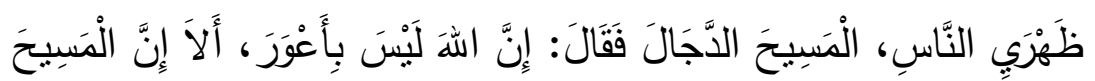

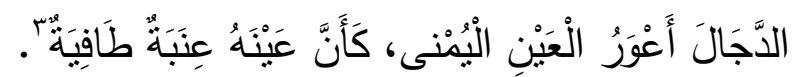

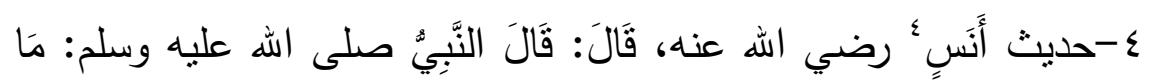

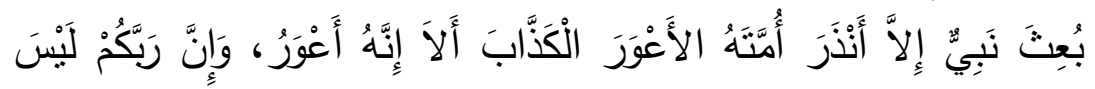

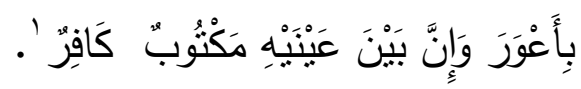

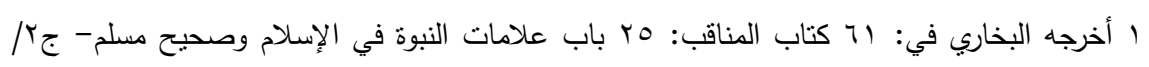

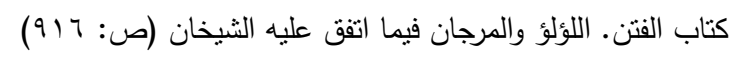

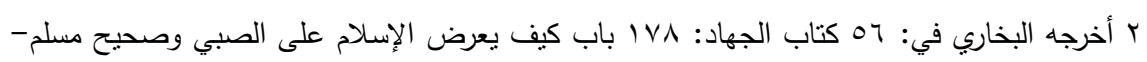

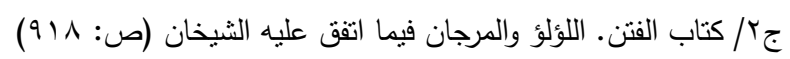

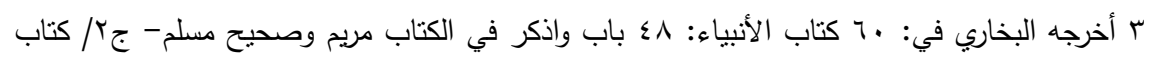

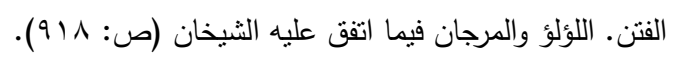

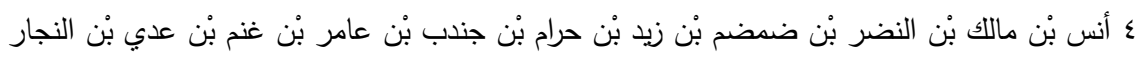

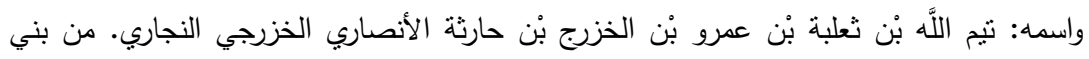
$=$ 
هن بلاغة الببي العدنان في دديثه عن فتن آذر الزهان فيها اتفق عليه الشيخان.

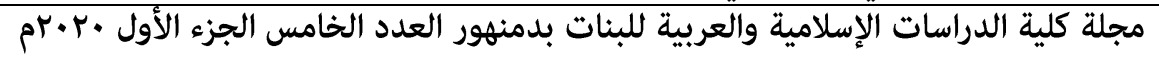

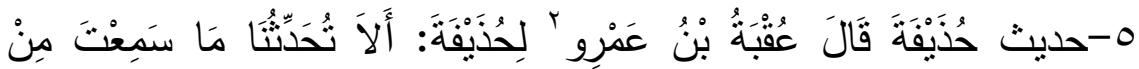

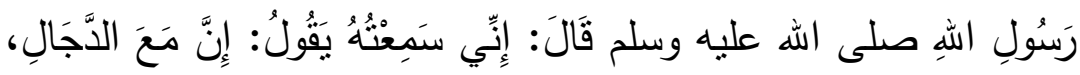

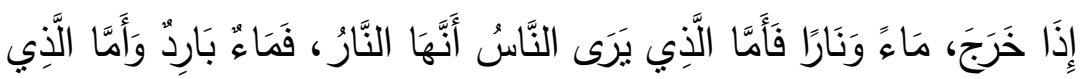

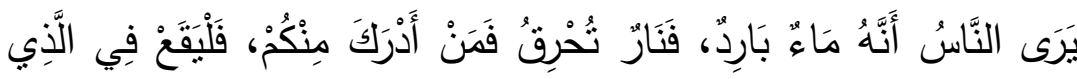

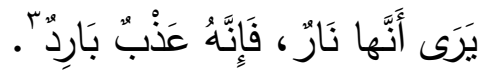

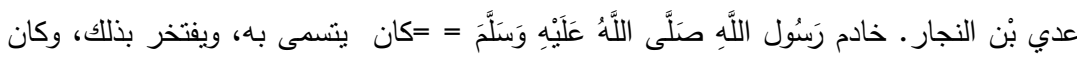

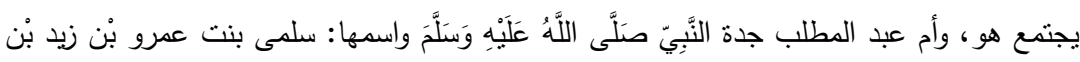

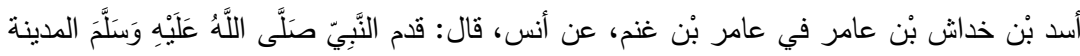

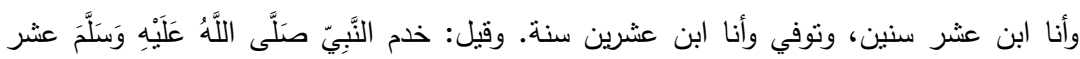

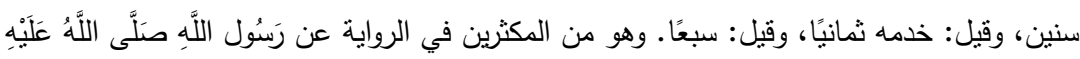

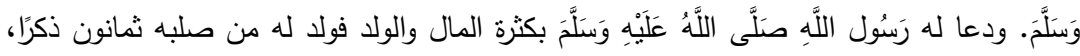

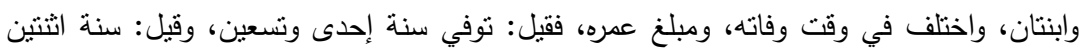

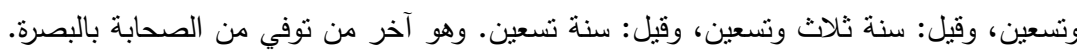

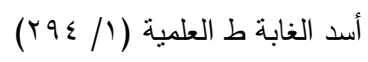

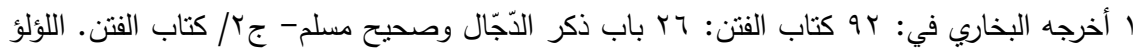

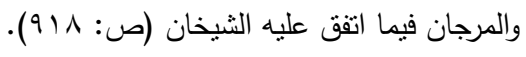

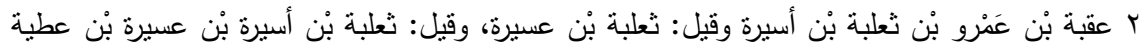

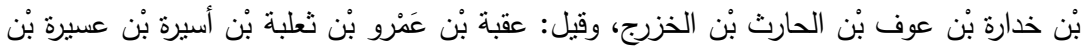

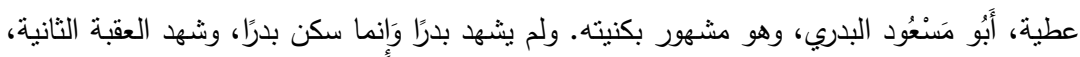

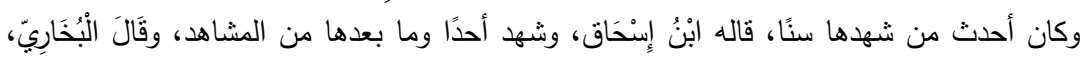

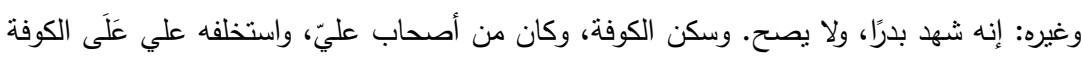

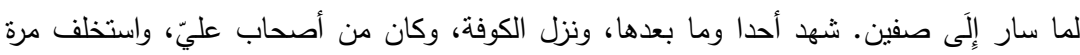

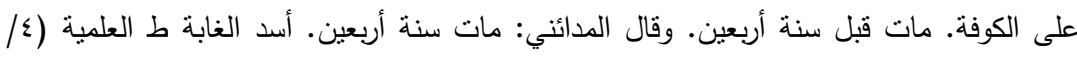

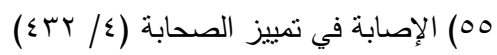

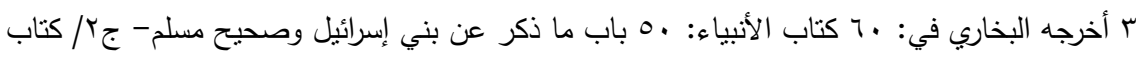

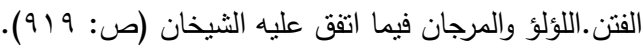


من بلاغة النبي العدنان في دليثه عن فتن آذر الزهان فيها اتفق عليه الشيخان.

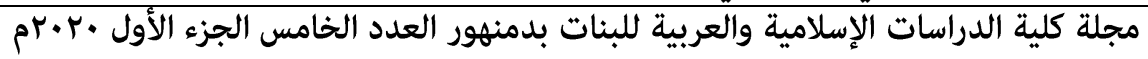

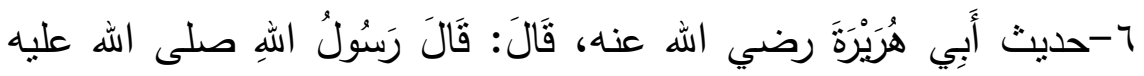

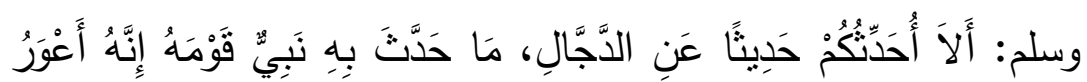

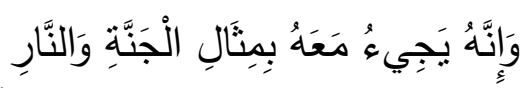

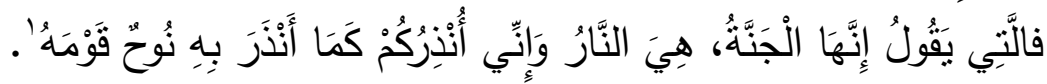
التحليل البلاغي والثرح:

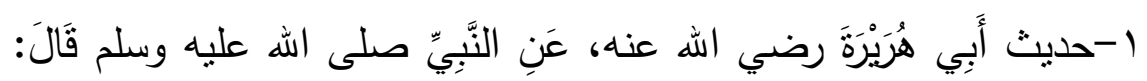

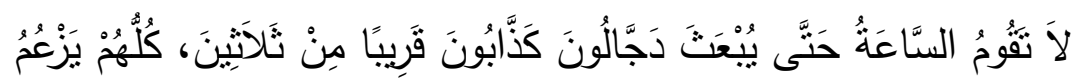
أَنَّهُهُ رَسنولُ اللهِه.

(لا تقوم الساعة حتى يُبحَث) يخرج ويظهر (دجالون) يقال دجل فلان الحق بباطله أي غطاه ويطلق على الكذب أيضًا، وحينئذٍ فيكون قوله ليه (كذابون) تأكيدًا (قريبًا) نصب حال من النكرة الموصوفة (من ثلاثثن) نفسًا، وفي مسلم من حديث جابر بن سمرة: إن بين يدي الساعة ثلاثثن كذابًا

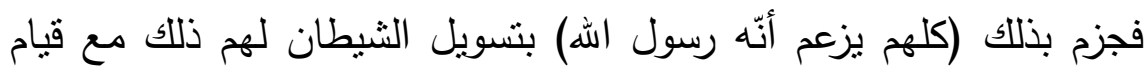
الشوكة لهم وظهور شبهة كمسيلمة باليمامة والأسود العنسي باليمن وكان ظهورهما في آخر الزمن النبوي، فقتل الثاني قبل موته -صَلَّى اللَّهُ عَلَيَهِ بَّه وَستلَّمَ-، ومسيلمة في خلافة أبي بكر وفيها خروج طليحة بن خويلد في بني لني

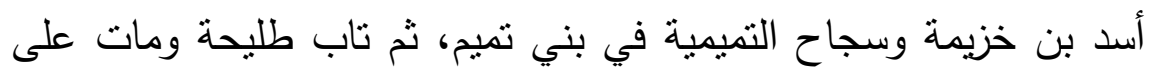

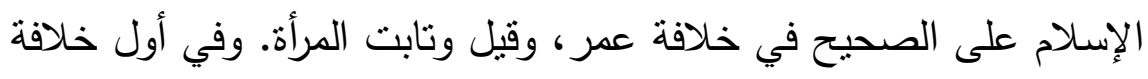
ابن الزبير خرج المختار بن أبي عبيد التقفي وتغلب على الكوفة ثم ادّعى ولى ونى

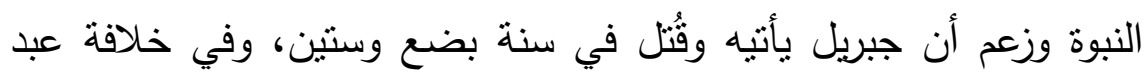

ا أخرجه البخاري في: ـ كتاب الأنبياء: ب باب قول الله عز وجل (ولقد أرسلنا نوحا إلى قومه) وصحيح

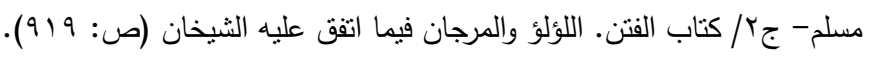




\section{من بلاغة النبي العدنان في دديثه عن فتن آذر الزمان فيها اتفق عليه الشيخان.}

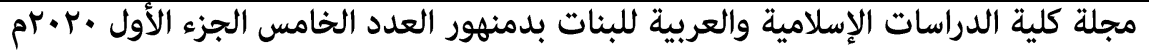

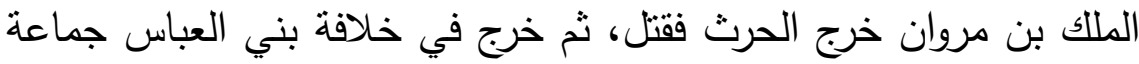
ادعوا ذللك بسبب ما نشأ لهم عن جنون أو سوداء وقد أهلك الله من وقع له له ذ'للك منهم ' r-حديث ابْنِ عُمَرَ قَالَ: ثُمَّه قَامَ النَّبِيٌُ صلى الله عليه وسلم، فِي النَّاسِ،

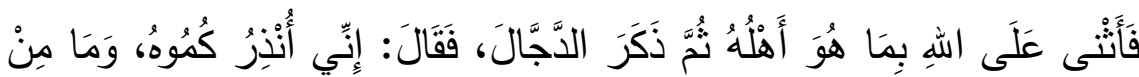

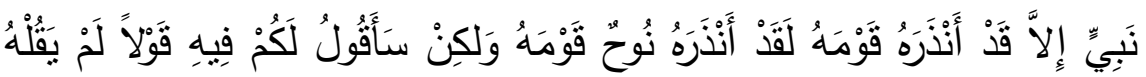

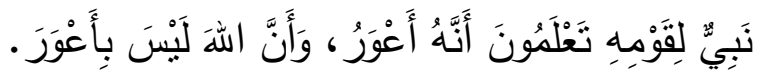

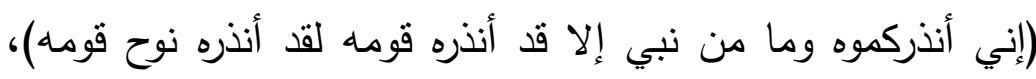
خصّ نوحًا بالذكر لأنه أبو البشر الثاني أو أنه أول مشرع (ولكن سأقول لكم

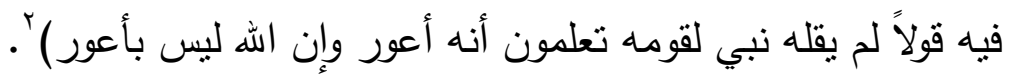

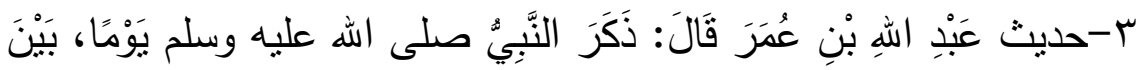

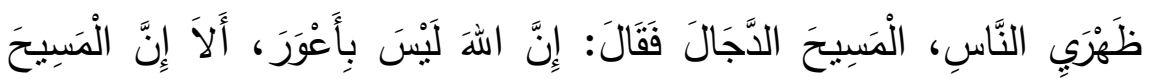

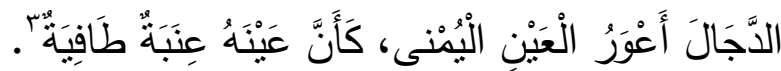

(بَيْنَ ظَهْرِي النَّاسِ )أي جالسًا في وسط الناس مستظهرًا لا مستخفيًا

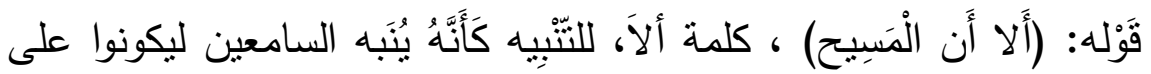

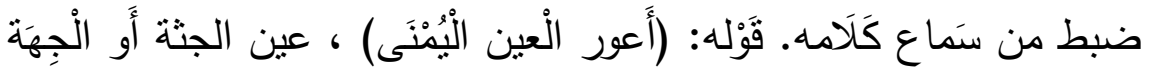

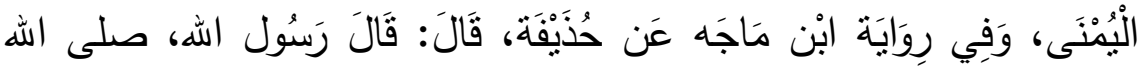

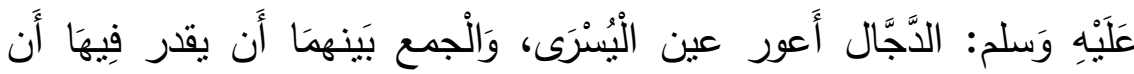

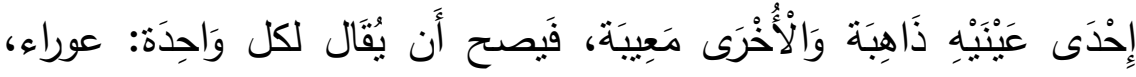

$$
\begin{aligned}
& \text { إرشاد الساري لشرح صحيح البخاري (T/OV) }
\end{aligned}
$$

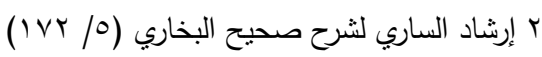

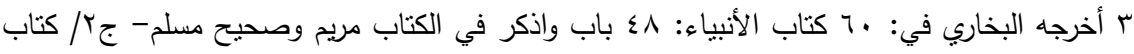

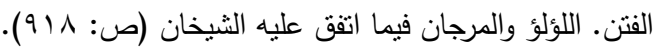


من بلاغة النبي العدنان في دلايثه عن فتن آذر الزمان فيها اتفق عليه الشيخان.

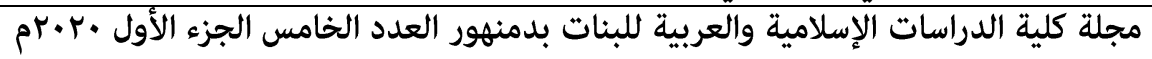

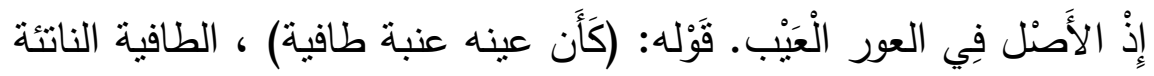

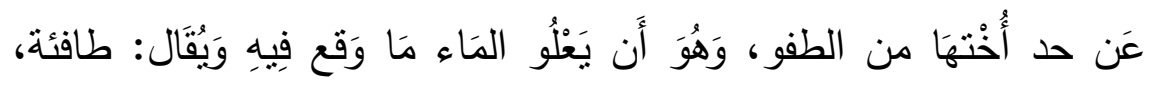

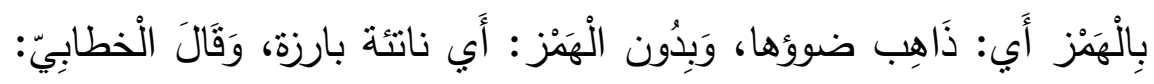

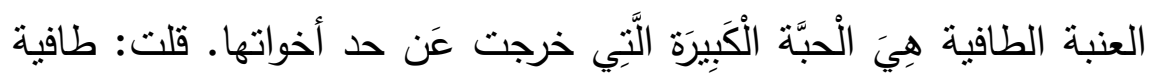

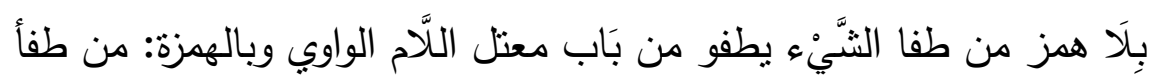

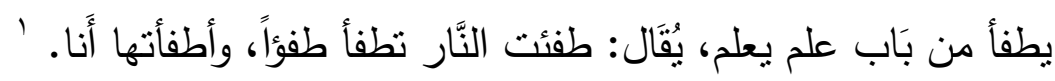

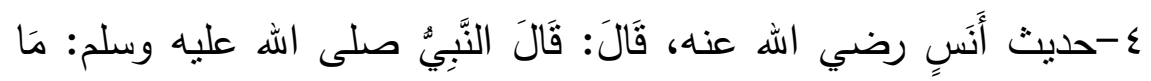

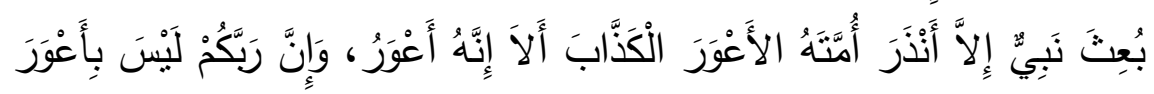

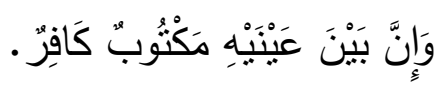

(ما بعث نبي إلاّ أنذر أمته الأعور الكذاب ألا) ألا حرف نتبيه (إنه

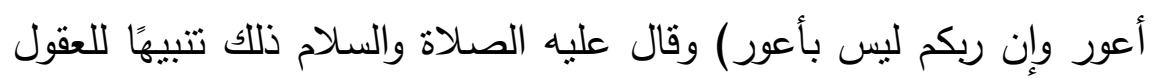
على حدوثه ونقصه، وإنما اقتصر على وصف اعلى الدجال بالعور مع أنها أن أدلة الحدوث كثيرة ظاهرة لأن العور أثز محسوس يدركه كل أحد فدعواه الربوبية مع نقص خلقته علم كذبه، لأن الإله يتعالى عن النقص (وإن بين عينيه مكتوب كافر) أي بين عينيه شيء مكتوب وذللك الثيء هو كلمة كافر ، وزاد أبو أمامة عند ابن ماجة يقراه كل مؤمن كاتب وغير كاتب وهذا إخبار بالحقيقة لأن الإدراك في البصر يخلقه اله للعبد كيف شاء ومتى شاء فهذا يراه المؤمن بعين بصره ولو كان لا يعرف الكتابة ولا يراه الكافر ولو كان

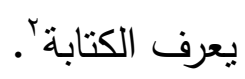

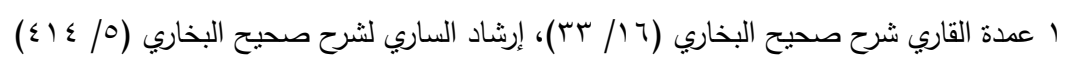

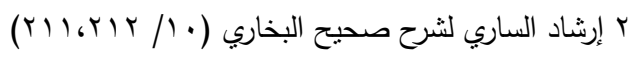


صن بلاغة النبي العدنان في دديثه عن فتن آذر الزهان فيها اتفق عليه الشيذان.

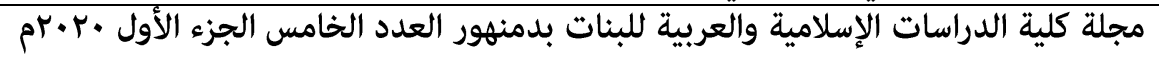

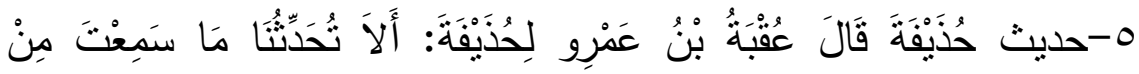

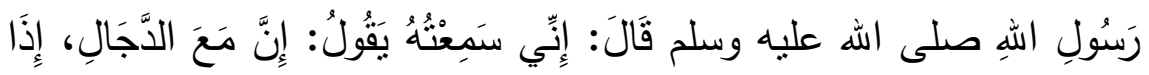

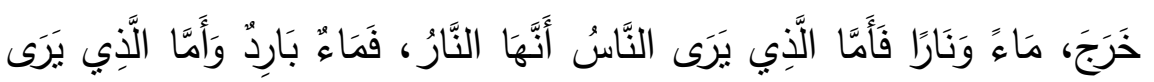

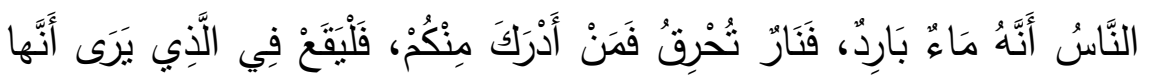

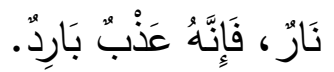

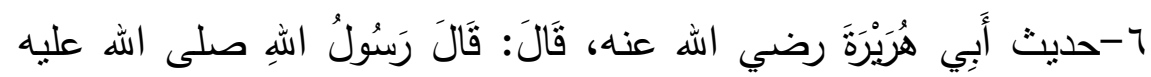

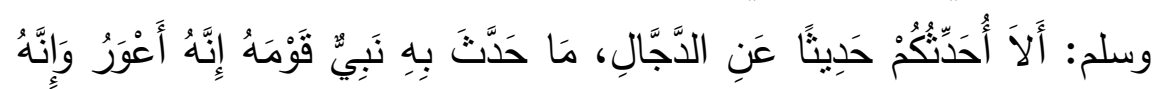

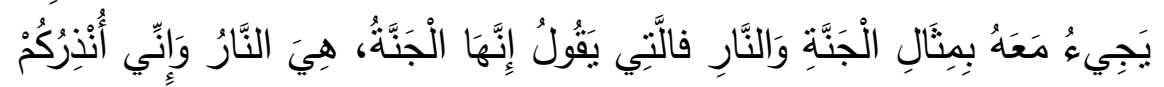

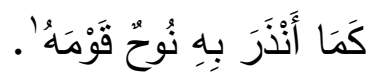

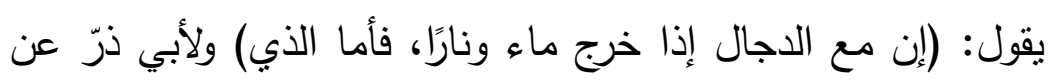

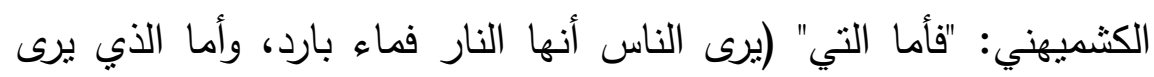
الناس أنه ماء بارد فنار تحرق؛ فمن أدرك) ذلك (منكم فليقع في الذي برى

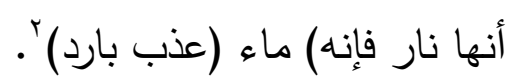

(ألا) بالتخفيف (أحدثكم حديثًا عن الدجال ما حدّث به نبي قومه: إنه) أي الدجال (أعور وإنه يجيء معه) إذا ظهر (بمثال الجنة ) ومثال

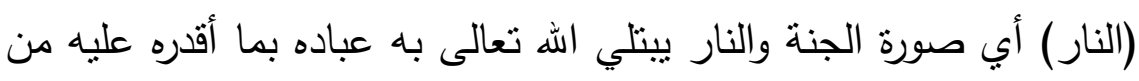
مقدوراته كإحياء الميت الذي يقتله وأمره السماء أن تمطر فتمطر ، والأرض الهاله أن تتبت فتتبت بقدرة الله تعالى ومشيئته، وفي مسلم عن أبي هريرة: "وإنه يجيء معه منل الجنة والنار، فالتي يقول إنه جنة هي النار وهذا من فنتنه التي امتحن الله بها عباده، ثم يفضحه الله تعالى ويظهر عجزه" ، فيقتله

ا أخرجه البخاري في: . ب كتاب الأنبياء: ب باب قول الله عز وجل (ولقد أرسلنا نوحا إلى قومه) وصحيح

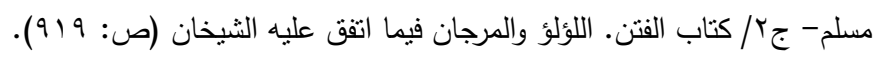

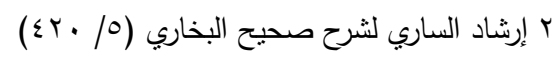


من بلاغة النبي العدنان في دايثه عن فتن آذر الزمان فيها اتفق عليه الشيخان.

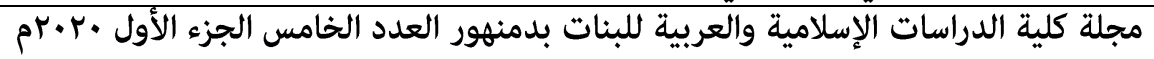
عيسى عليه السلام (فالتي يقول إنها الجنة هي النار) وبالعكس لإنس (وإني) بالواو أو لابن عساكر فإني (أنذركم) أخوّفكم منه (كما أنذر به نوح قومه).

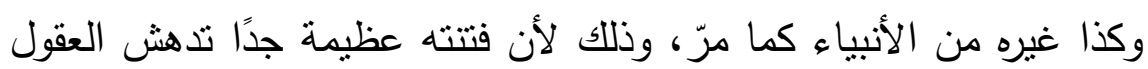
وتحير الألباب مع سرعة مروره في الأرض فلا يمكث بحيث يتأمل الضعفاء دلائل الحدوث والنقص فيصدقون بصدقه في هذه الحالة، فلذا حذرت هروت الات الأنبياء عليهم الصلاة والسلام قومهم من فتتته ونبهوا عليه' . ويلاحظ في الأحاديث الستة ترقي البيان النبوي، من إخبار عن ونه دجالين ومدعي النبوة، إلى مدعي الألوهية الدجال الأعور ، ويأتي الحديث الأول يخبر مجرد إخبار أن هناك قرابة الثناثين من سيدعون النبوة، وكلهم التهاته سيزعم أنه رسول، مصدرا حديثه بقوله في أغلب حديث أثنراط الساعة وآخر الزمان(لاتقوم الساعة حتى...) ذلك الأسلوب الذي ينبه المتلقي لما يلقى بعد الته

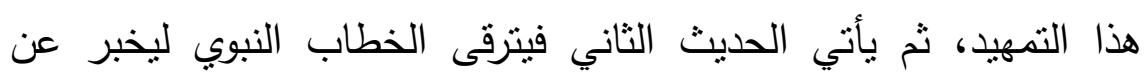

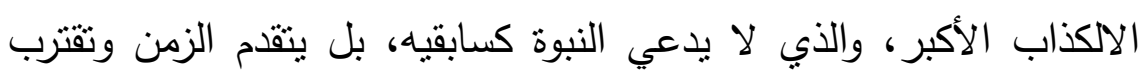

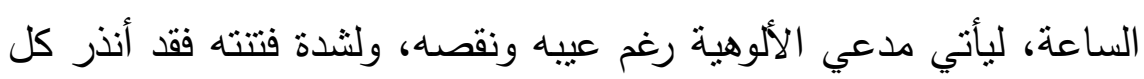
نبي قومه هذا الدجال، من لان نوح عليه السلام أبو البشر الثاني. وفي إيجاز بليغ من الرسول المعلم يقول: إني أنذركموه، جملة

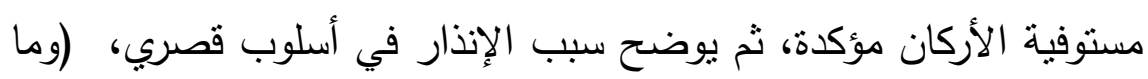

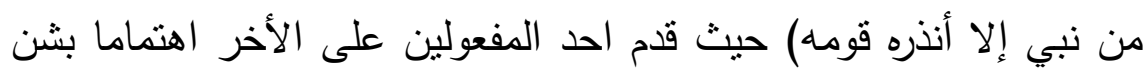
ذلك المقدم لأنه المعني بالإنذار، ثم زاد النبي صلى الله عليه النه وسلم في

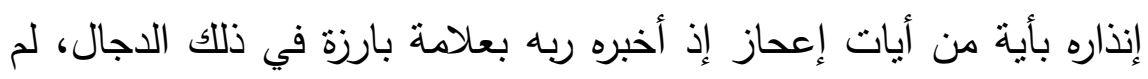

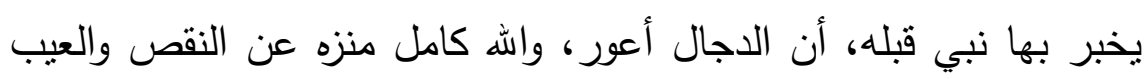

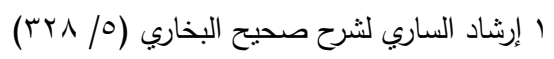


صن بلاغة النبي العدنان في دديثه عن فتن آذر الزهان فيها اتفق عليه الشيذان.

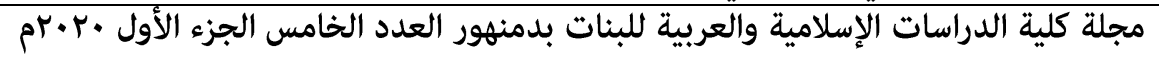

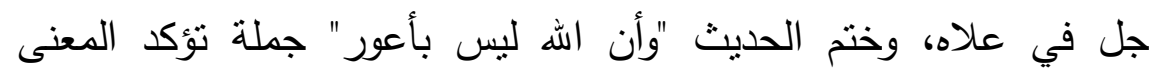

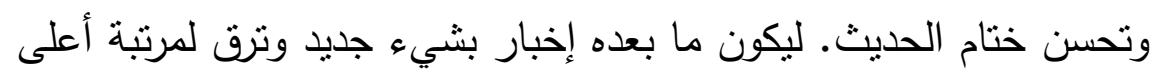

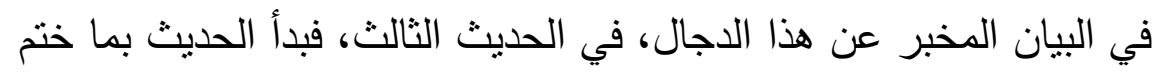
به الثاني فقال: "إن الله ليس بأعور، ثم أكد ب"ألا" و "إن" على أن الدجال

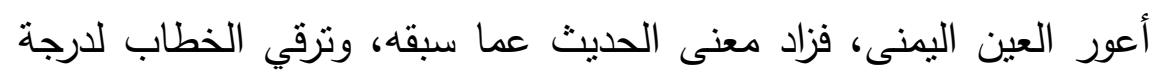
أعلى في الوضوح والبيان. ثم زاد فثبه تلاك العين بالعنبة الطافية، تصويرا لتلك الصورة المقززة المعيبة، التي لا يمكن معها ادعاء النبوة، وهي في البشر، فما بالنا بادعاء الألوهية، والعجب كل العجب لمن يصدق هذا

\section{ويتبعه!}

ثم يأتي الحديث الرابع ليؤكد ويزيد التأكيد تأكيدا، على حقيقة الدجال وصفته، ولكنه يرتفع بالمعنى درجة أعلى (وإن بين عينيه مكتوب كافر).

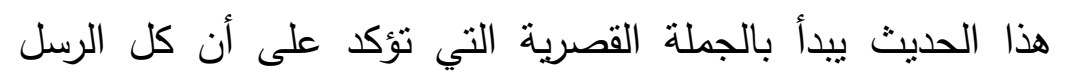

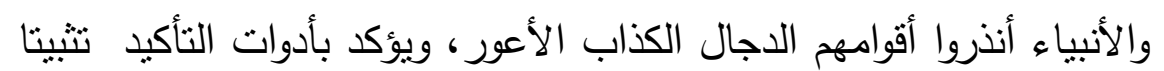
للمعنى، وتحفيظا لمن سمع، وتتبيها لمن لم يسمع (ألا إنه أعور وإن ربكم بادئ

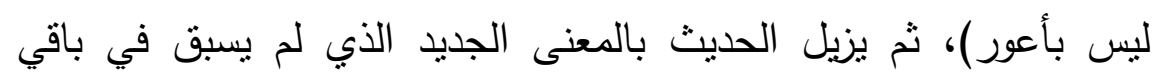

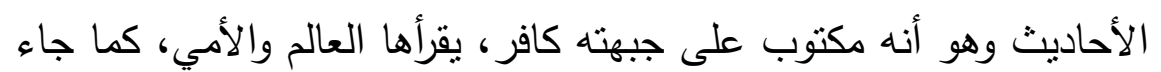
في بعض روايات الحديث. ثم يأتي الحديثان الأخيران ليوضحان وسيلة الدجال لفتتة الناس، بأن

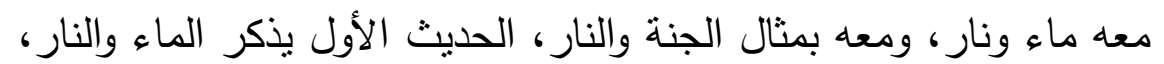
ويترقى الحديث الأخير لييرز الصورة مكتملة واضحة المعالم، لفتتة ذلك

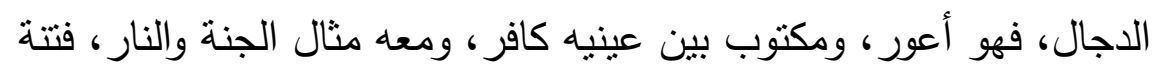

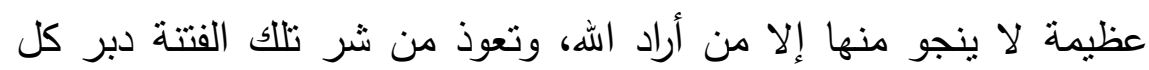
الصلاة وقبل التسليم من التشهد الأخير كما ورد عن رسول الله صلى الله 
من بلاغة النبي العدنان في دايثه عن فتن آذر الزهان فيها اتفق عليه الشيذان.

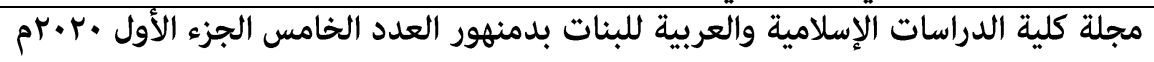
عليه وسلم، وقرأ سورة الكهف، وحفظا عشرا منها، كما جاء في فضائل سور القرآن. ولأن الحديث الأخير كجامع لكل معاني الأحاديث السابقة عليه، بدأ بذللك الاستفهام التحضيضي الذي يراد به تحفيز الأذهان للتلقي لتعي مان

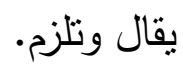

(ألا أحدثكم حديثا عن الدجال ما حدث به نبي قومه؟" ولم ينتظر

جوابا، بل كان السؤال لثد الانتباه وإيقظ الذهن. وهو وسيلة تعليمية وأداة لخلق دافع، ولأن في السؤال إبهام ويأتي الجواب ليزيل الإبهام ويوضحهد. فائدة الإيضاح بعد الإبهام: تمكين المعنى في نفس المتلقي تمكينا

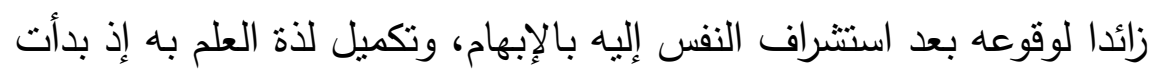

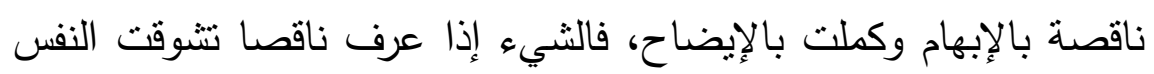

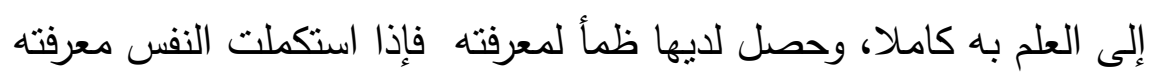
كانت لذتها أثند من حصول العلم به دفعة واحدة'.

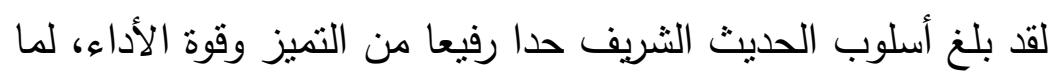
تضمنته جمله من خصائص بلاغية تتصل بقوة الألفاظ في مواضعها، من

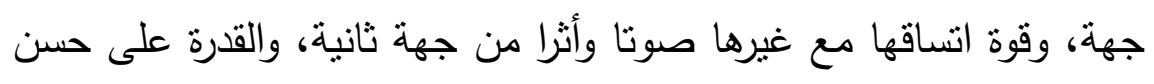
تقسيم الجمل تقسيما يتيح للذهن أن يشبع رغبته في التطلع لما خفي عليه،

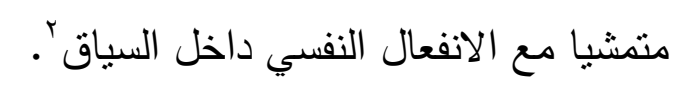
وأخيرا كان للطباق دوره في استحضار صورة الضد في الذهن في

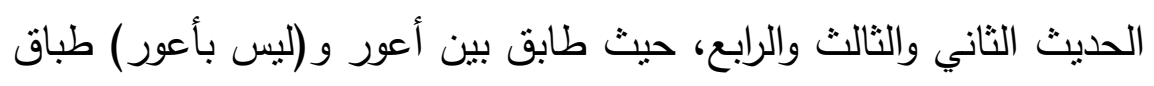
سلب؛ ليوضح الفرق بين الكذب والحقيقة، ثم جاء الحديثان الخامس

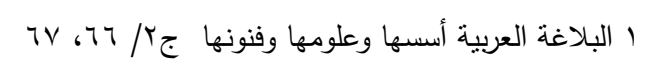

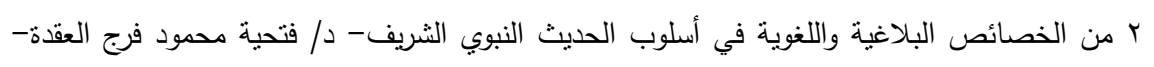

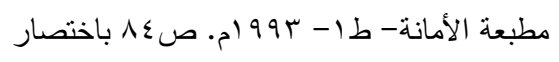


صن بلاغة النبي العدنان في دديثه عن فتن آذر الزهان فيها اتفق عليه الشيذان.

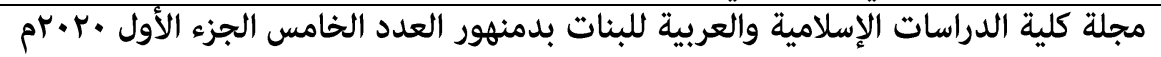

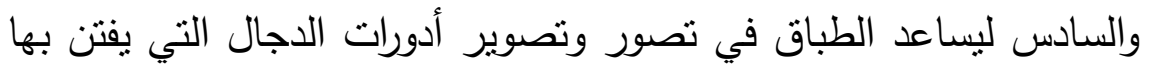
الناس، فمعه ماء بارد، باطنه نار تحرق، والعكس ، ومعه مثال الجنة والنار ، فجنته نار وناره جنة.

إن البيان النبوي واضح غاية الوضوح في الحديث عن الفتن، كلامه لا يحتمل التأويل، ليكون للعامين نذيرا، وليحفظ أمته من شر الفتن المهلكة، التي أخبر بحدوثها بعلم أطلاعه الله عليها. صلى الله عليه وسلم.

\section{ثانيا: خروج يأجوج ومأجوج}

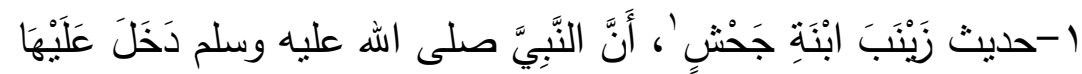

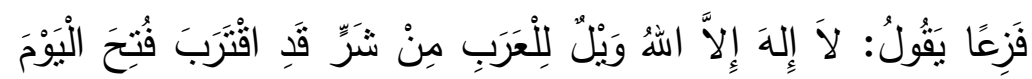

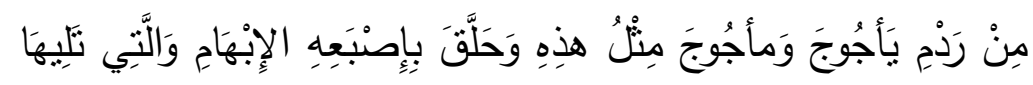

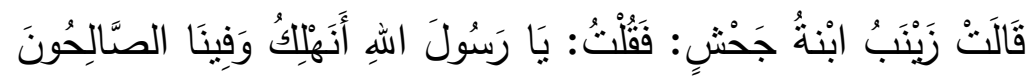

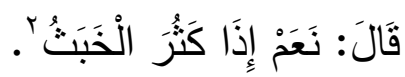

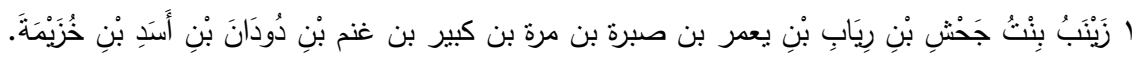

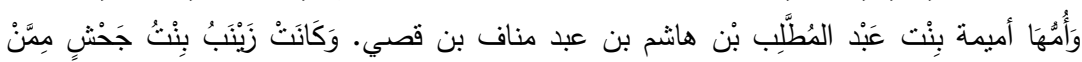

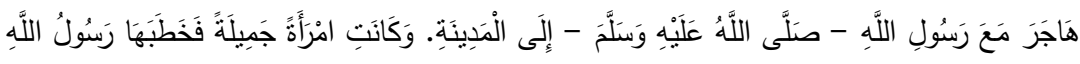

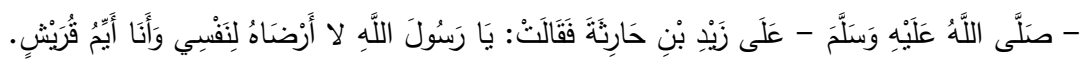

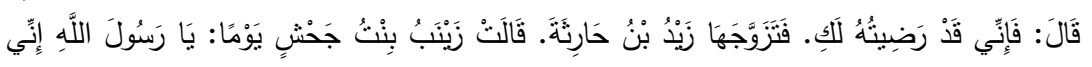

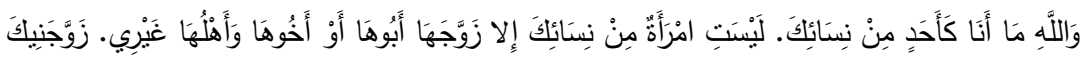

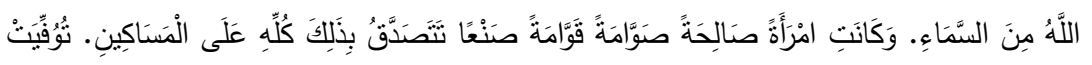

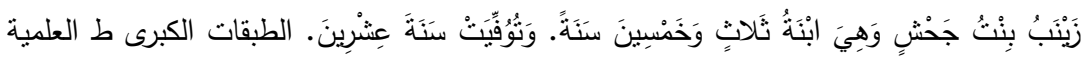

(9):^・/ / )

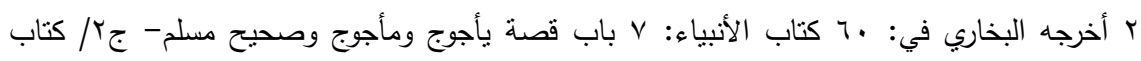

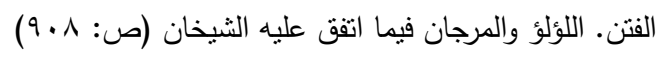


من بلاغة النبي العدنان في دايثه عن فتن آذر الزمان فيها اتفق عليه الشيخان.

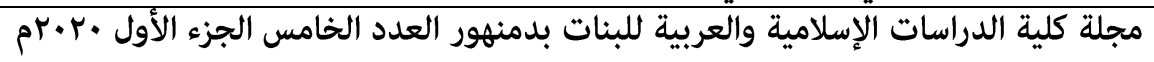

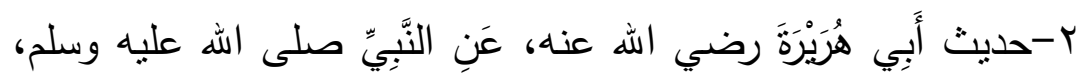

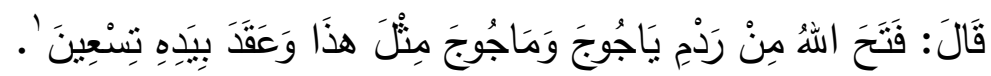

\section{التحليل البلاغي والشرح:}

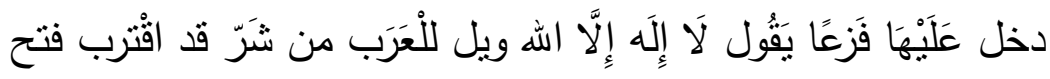

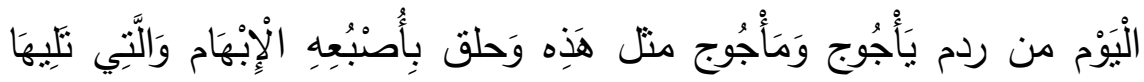

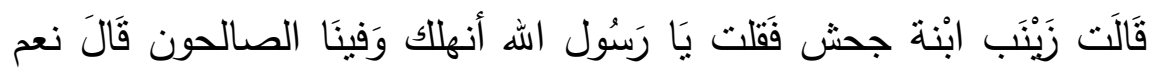

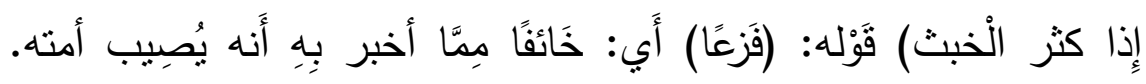

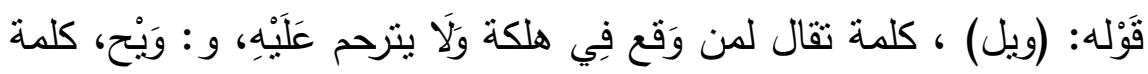

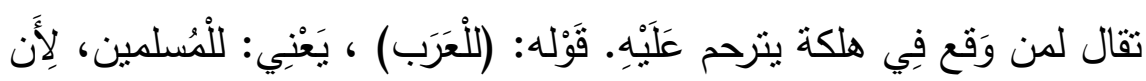

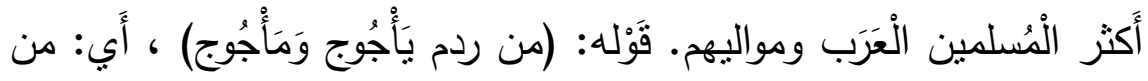

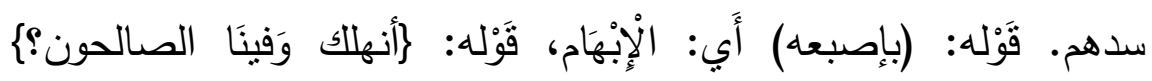

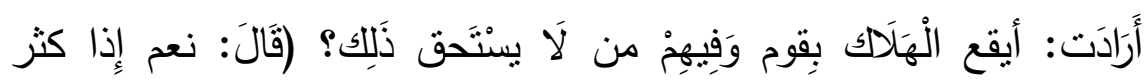

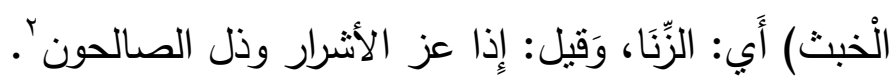

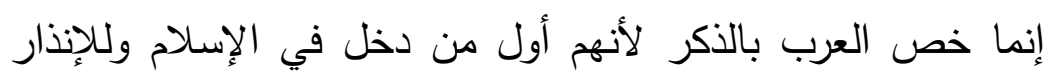
بأن الفتن إذا وقعت كان الهلاك أسرع إليهمَّ .

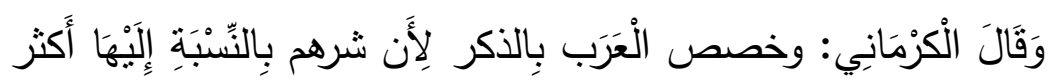

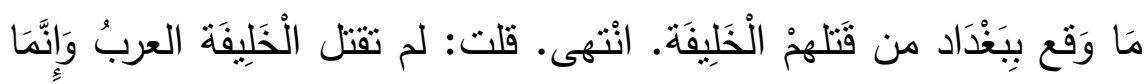

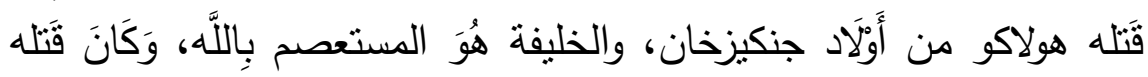

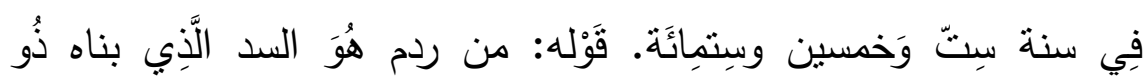

ا أخرجه البخاري في: ـ كتاب الأنبياء: V باب قصة ياجوج وماجوج وصحيح مسلم- جr/ كتاب

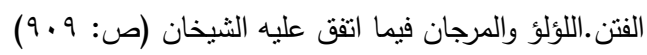

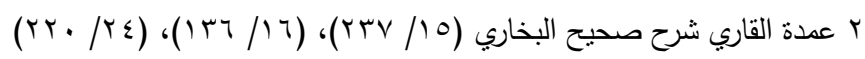

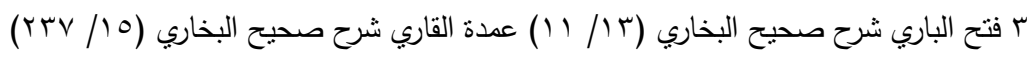


صن بلاغة النبي العدنان في دديثه عن فتن آذر الزهان فيها اتفق عليه الشيذان.

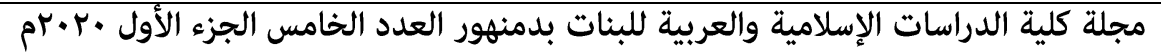

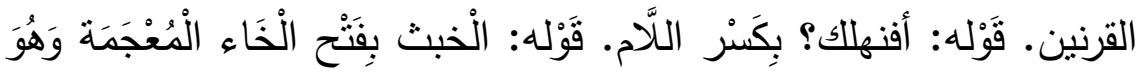

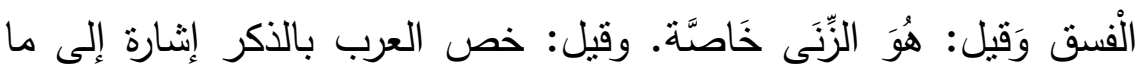
وقع من قتل عثمان منهم أو أراد ما يقع من مفسدة يأجوج ومأجوج أو من لن إنى الترك من المفاسد العظيمة في بلاد الإسلام، والظاهر أنه المعاصي مطلقًا' .

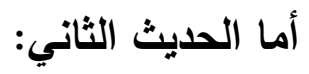

حديث أَبِي هُرَيْرَةَ رضي الله عنه، عَنِ النَّبِِّ صلى الله عليه وسلم،

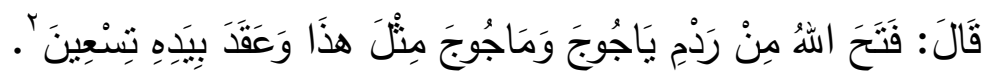
(فتح اله من ردم يأجوج ومأجوج منل هذه وعقد بيده تسعين) والمراد بالتمثيل التقريب لا حقيقة التحديد، وقد سبق أنهم يحفرون كل يوم حتى لهـ لا يبقى بينهم وبين أن يخرقوه إلا يسير فيقولن غدًا نأني فنفرغ منه فيأنون إليه فيجدونه عاد لهيئته، فإذا جاء الوعد قالوا عند المساء غدًا إن شاء الله تعالى فإذا أنوا نقبوه وخرجوا؟ّ. إن أول ما بطالعنا في الحديث الأول هو كلمة التوحيد، "لا إله إلا الله" جملة قصرية بطريق النفي والاستثناء، كان صلى الله عليه وسلم دائم الذكر لها في الرضا والغضب، وحتى عند العجب، وهنا يتعجب مما أطلعه ربه عليه من الغيب، من فتن تترى، نتابع حتى قرب نهاية الدنيا، وهي خروج يأجوج ومأجوج. والنفي والاستثناء سبيل من سبل خطاب المنكر لئر

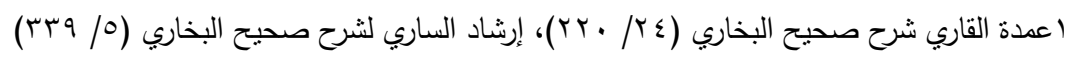

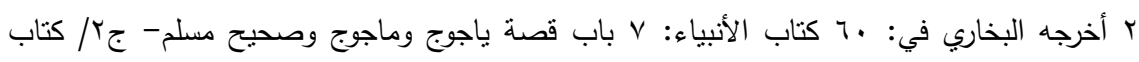

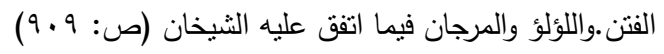

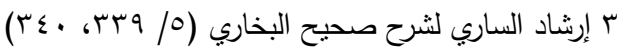


من بلاغة النبي العدنان في دديثه عن فتن آنر الزمان فيها اتفق عليه الشيخان.

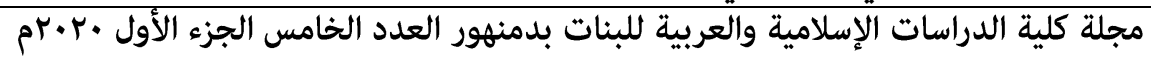

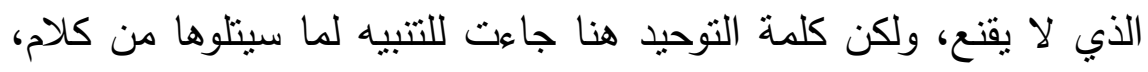

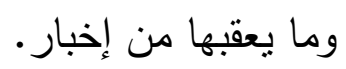

ولي كلمة التوحيد الدعاء بالويل، والهالك، والويل واد في جهنم،

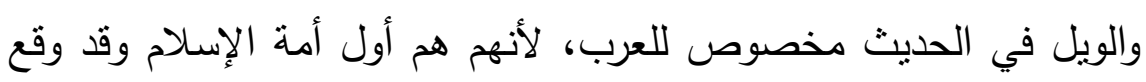
فيهم من الفتن والمهاللك ما بشر بها الصادق المصدوق، من هلاك على يد التتار، والمغول، لذا كانوا المعنيين بالتحذير هنا، ومن دان بدينهر من هن هن بعدهم. ويلاحظ جمال الإيقاع المتولد من حسن فواصل الجمل، بين "عرب" و "|فترب" وما خلفه وراءه من انتباه يقظ، وحس مستيقظ لما سيتلو من بيان لهذا الثر المقترب. وقد أثز البيان النبوي هنا استخدام كلمة الردم دون غيرها، تأثرا بالقرآن الكريم، فقد استخدمها في نفس الموضوع، كما أن الأصل اللغوي لني لنيان ينبئ عن دقة استخدام البيان القرأني والنبوي لهذه الكلمة فجاء في اللسان:

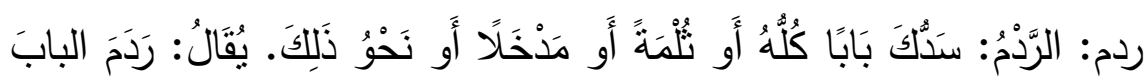

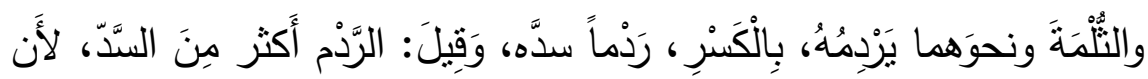

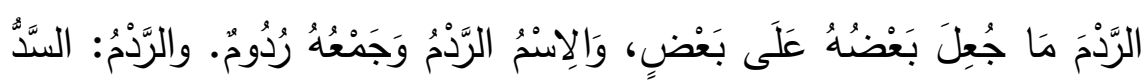

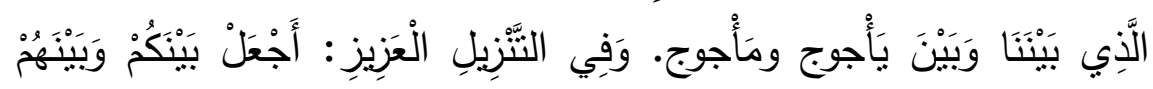

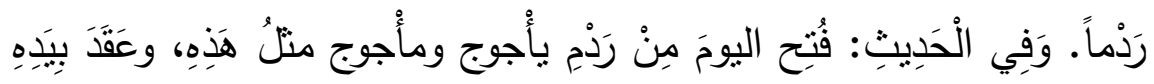

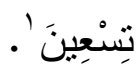

وأخيرا التمثيل بالإشارة والذي تكرر بين الحديثين وهو وسيلة إفهام، وطريقة لتقريب المعنى وربطه بإثارة أثبت في الحفظ دون خلوه منها. 


\section{صن بلاغة النبي العدنان في دلديثه عن فتن آذر الزمان فيها اتفق عليه الشيذان.}

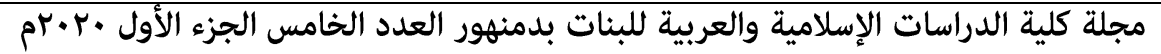

فإن البيان النبوي لم يقصر في شيء، ولم يبالغ في شيء حد النفور،

بل اتسق له من هذا الأمر على كمال الفصاحة والبلاغة ما لو أراده مريد لعجز عنه، ولو هو استطاع بعضه لما تم له في كل كلامه، لأن مجرى له له الأسلوب على الطبع، والطبع غالب مهما تشدد المرءُ وارتاض ومهما تثبت وبالغ في التحفظ. هذا إلى أن اجتماع الكلام وقلة ألفاظه، مع اتساع معناه وإحكام أسلوبه في غير تعقيد ولا تكلف، ومع إبانة المعنى واستغراق أجزائه،

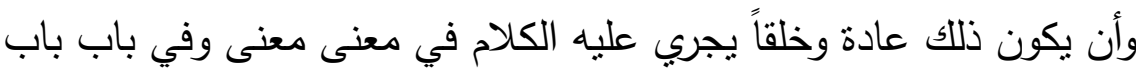
- شيء لم يعرف في هذه اللغة لغيره - صلى الله عليه وسلم - فكان تيسير ذللك للنبي - صلى الله عليه وسلم - واستجابته على ما بريد وعلى النحو الذي خرج به - نوعاً من الخصائص التي انفرد بها دون الفصحاء والبلغاء

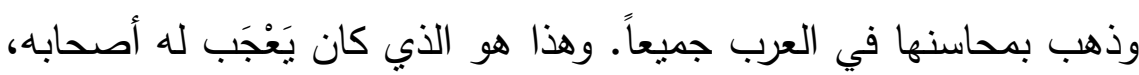

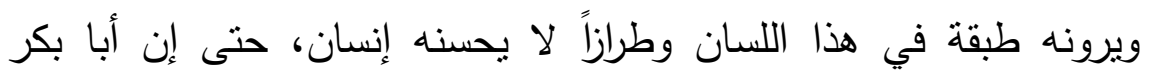
رضي الله عنه قال لله مرة: لقد طفت في العرب وسمعت فصحاءهم، فما سمعت أفصح منك؛ فمن أدبك (أي علمك) ؛ قال: " أدبني ربي فأحسن

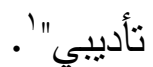


صن بلاغة النبي العدنان في دايثه عن فتن آنر الزهان فيها اتفق عليه الشيخان.

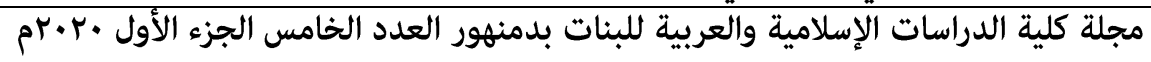

\section{خاتمة}

بعد هذه الرحلة غير العادية مع أحداث غير عادية، حدثت وتحدث وستحدث في أزمنة متتالية إلى قيام الساعة، ووقوف جميع المخلوقات أمام رب البرية، يطيب للبحث أن برصد بعد الومضات والنتائج لدراسة هذا البيان العالي من أحاديث خير البرية، ويمكن إجمال أهمها فيما يأتي:

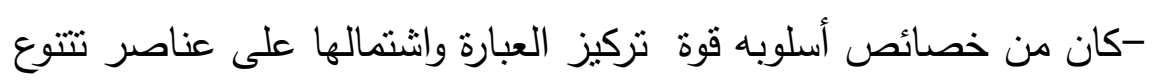
بتتوع الموقف التي تدل عليه، تعبيرا وتأثثرا في إطار من الإيجاز الذي لتي تتتقى ألفاظه انتقاء دالا، له من الثراء والعمق ما يحقق غايته. -قل كلامه وخرج قصداً في ألفاظه، محيطاً بمعانيه، تحسب النفس قد اجتمعت في الجملة القصيرة والكلمات المعدودة بكل معانيها: فلا ترى من الكلام ألفاظاً ولكن حركات نفسية في ألفاظ، وإشارات نساعد على لئى حسن إفهام المعتى. -تدرج البيان النبوي في حديثه عن الفنن، فكان من أخبر عنها مرة واحدة، وكان من الفتن من أنذر من ملابستها، حذرا وخوفا من سوء عاقبتها، ككثرة القتل، والتحذير من الجدال.

-ترقى البيان النبوي في حديثه عن الدجال، فجاء في كل حديث بمعنى جديد زائد عن غيره، وبدأ بدون تأكيد ثم تدرج كذلك في التأكيد ترهيبا وتخويفا وإنذارا.

-تتوعت ألوان البلاغة التصويرية بين تصوير بالكلمة وبالإيقاع والتتبيه وبالاستعارة، وحتى بالإشارة، لاستجلاء المعنى وحن توصيله للأفهام.

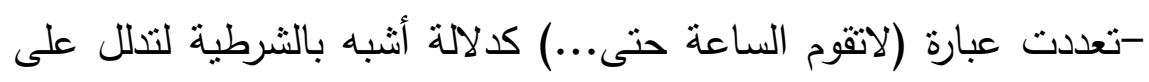
صدق وقوع ما يكون بعدها، مهما بدى مستبعدا وغريبا على الأفهام. 
من بلاغة النبي العدنان في دديثه عن فتن آذر الزهان فيها اتفق عليه الشيخان.

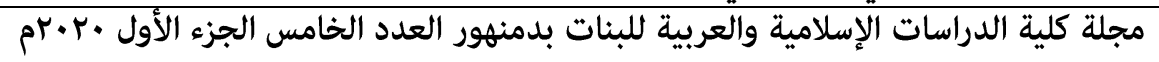

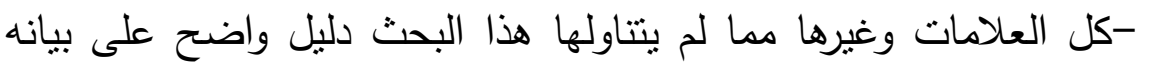

العالي، وصدق نبوته صلى الله عليه وسلم، فهو لا ينطق عن الهوى إن له لهائ

$$
\text { هو إلا وحي يوحى. }
$$

-وأخيرا فإن ثراء الاحتمالات في توجيه النص وتعدد المعنى الوظيفي للمبنى الواحد طبيعة في البيان العالي، وسمة من سمات الكلام الأول لأنها تتكاتف ليفسر بعضها بعضا، في محاولة لاستقصاء جوانب المعنى، وإدراك علاقاته، والسياحة في جوه وآفاقه.

رزقنا الله القبول في الانيا وجنبنا الفتن ورزقنا شفاعة الصادق المؤتمن. وما توفيقي إلا بالله عليه توكلت وإليه أنيب 
من بلاغة النبي العدنان في دديثه عن فتن آذر الزهان فيها اتفق عليه الشيخان.

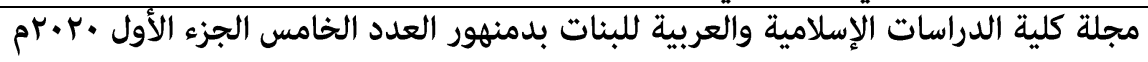

ثبت المصادر والمراجع

إرشاد الساري لشرح صحيح البخاري- أحمد بن محمد بن أبى بكر

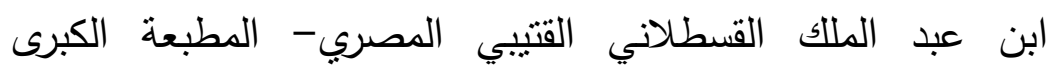

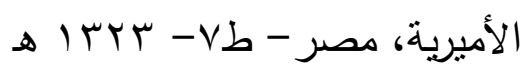

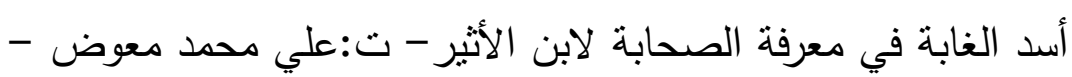

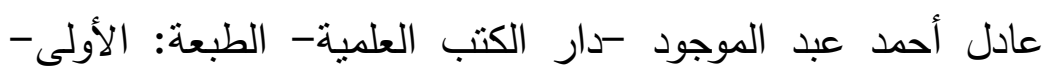

. $199 \leq-1 \leq 10$

الإصابة في تمبيز الصحابة- أبو الفضل أحمد بن علي بن محمد بن

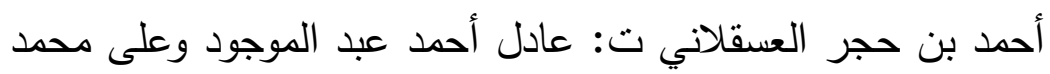

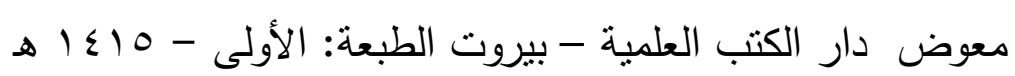

إعجاز القرآن والبلاغة النبوية لمصطفى صادق الرافعي -دار الكتاب

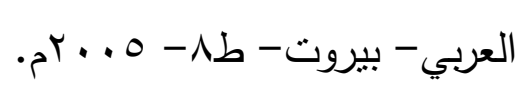

بلاغة تطبيقية .دراسة لمسائل البلاغة من خلال النصوص-

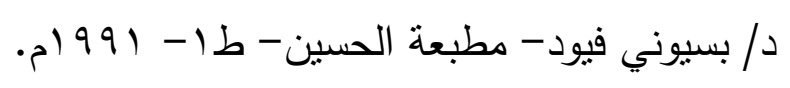

البلاغة العربية أسسها وعلومها وفنونها لعبد الرحمن حسن حبنكة الرينة

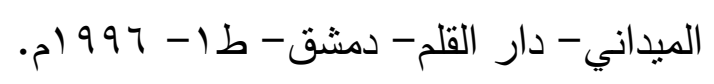

البلاغة العربية في ثوبها الجديد لبكري شيخ أمين- دار العلم

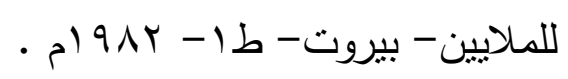

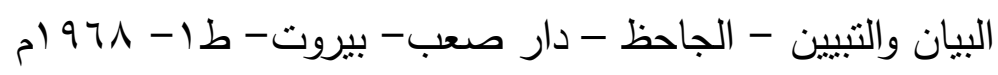

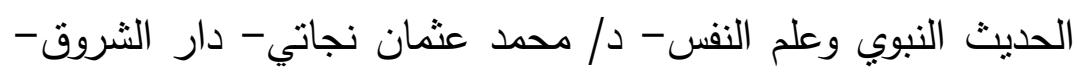

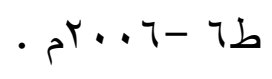

صحيح مسلم- دار الكتب العلمية- بيروت- لبنان.

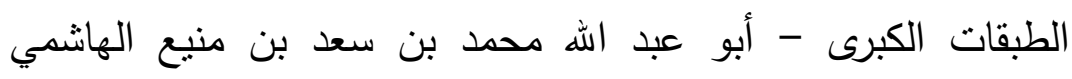

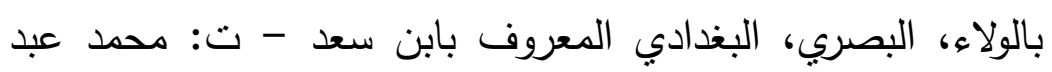


هن بلاغة النبي العدنان في دديثه عن فتن آذر الزهان فيها اتفق عليه الشيخان.

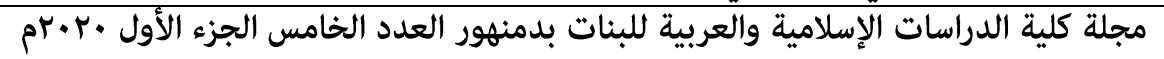

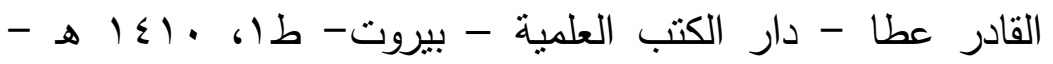

$$
\text { . } 199 \text {. }
$$

عمدة القاري شرح صحيح البخاري - أبو محمد محمود بن أحمد ابن موسى بن أحمد بن حسين الغيتابى الحنفى بدر الدين العينى -

$$
\text { دار إحياء التراث العربي - بيروت. }
$$

فتح الباري بشرح صحيح البخاري للحافظ بن حجر العسقلاني -ت: طه

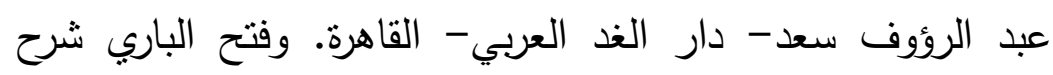
صحيح البخاري- لأحمد بن علي بن حجر أبو الفضل العسقلاني

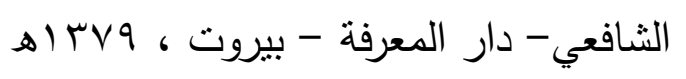

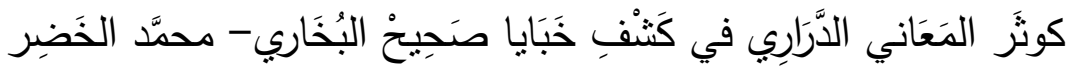

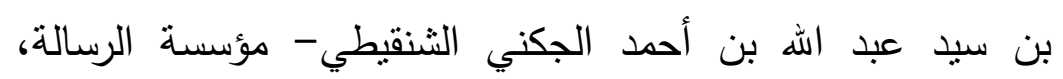

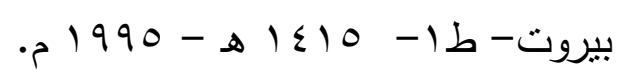

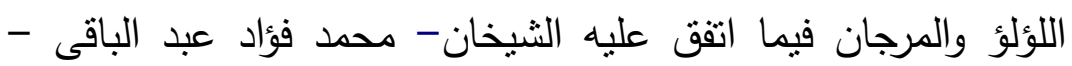

$$
\text { دار الفكر · بيروت }
$$

لسان العرب لابن منظور - دار المعارف.

معجم مقاييس اللغة لأحمد بن فارس بن زكرياء القزويني الرازي -

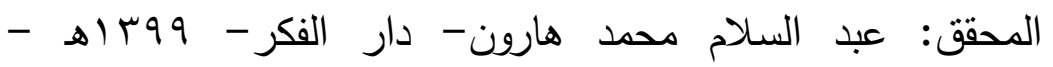

$$
\text { - }) 9 \vee 9
$$

من الخصائص البلاغية واللغوية في أسلوب الحديث النبوي الثريف-

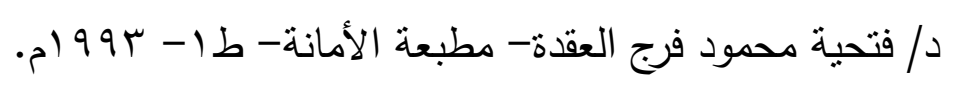

من فقه الفنن في ضوء السنة- د/ عبد الله شعبان - دار البشير للانقافة

$$
\text { والعلوم- طنطا. طا - } 999 \text { (م. }
$$




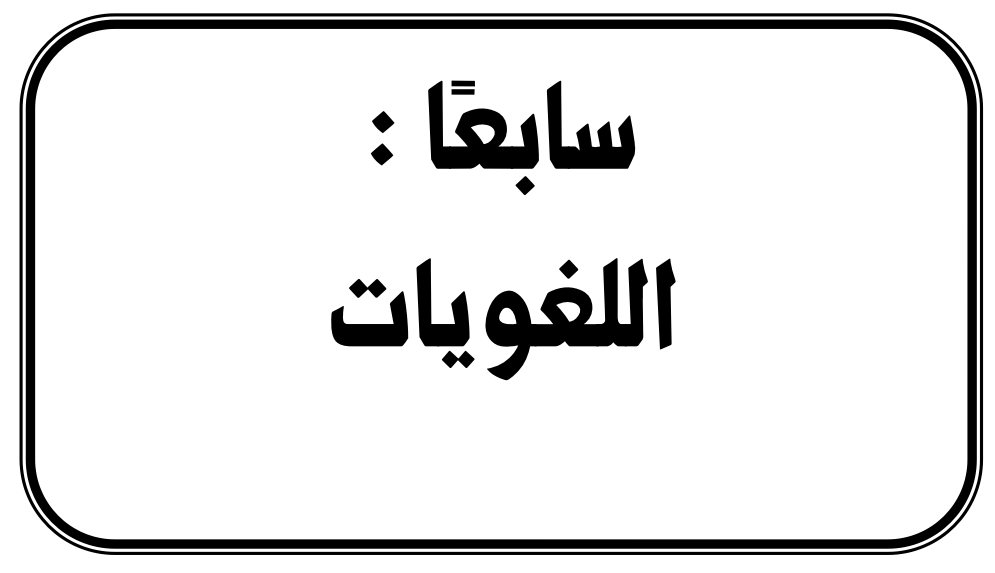


